Früh-Green, G.L., Orcutt, B.N., Green, S.L., Cotterill, C., and the Expedition 357 Scientists Proceedings of the International Ocean Discovery Program Volume 357

publications.iodp.org

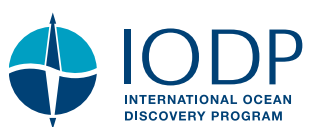

INTERNATIONAL OCEAN
DISCOVERY PROGRAM

doi:10.14379/iodp.proc.357.102.2017

\title{
Expedition 357 methods $^{1}$
}

G.L. Früh-Green, B.N. Orcutt, S.L. Green, C. Cotterill, S. Morgan, N. Akizawa, G. Bayrakci, J.-H. Behrmann, C. Boschi, W.J. Brazelton, M. Cannat, K.G. Dunkel, J. Escartin, M. Harris, E. Herrero-Bervera, K. Hesse, B.E. John, S.Q. Lang, M.D. Lilley, H.-Q. Liu, L.E. Mayhew, A.M. McCaig, B. Menez, Y. Morono, M. Quéméneur, S. Rouméjon, A. Sandaruwan Ratnayake, M.O. Schrenk, E.M. Schwarzenbach, K.I. Twing, D. Weis, S.A. Whattam, M. Williams, and R. Zhao ${ }^{2}$

Keywords: International Ocean Discovery Program, IODP, RRS James Cook, Expedition 357, Site M0068, Site M0069, Site M0070, Site M0071, Site M0072, Site M0073, Site M0074, Site M0075, Site M0076, seabed drills, RD2, MeBo, Atlantis Massif, Atlantis Fracture Zone, MidAtlantic Ridge, Lost City hydrothermal field, serpentinization, detachment faulting, oceanic core complex, hydrogen, methane, deep biosphere, carbon cycling, carbon sequestration, contamination tracer testing

\section{Introduction}

This chapter documents the primary procedures and methods employed by the operational and scientific groups during the offshore and onshore phases of International Ocean Discovery Program (IODP) Expedition 357. This information concerns only shipboard and Onshore Science Party (OSP) methods described in the site chapters. Methods for postexpedition research conducted on Expedition 357 samples and data will be described in individual scientific contributions. Detailed drilling and engineering operations are described in the Operations section of each site chapter.

\section{Site locations}

For all sites, coordinates supplied by the proponents from previous site surveys were used as a guide for positioning at the proposed coring locations (Figure F1). Coordinates were supplied to the bridge via daily operations plans and were used to center the dynamic positioning (DP) system over the specific drill operating at each site (i.e., the Meeresboden-Bohrgerät 70 [MeBo] drill at the stern of the vessel and the British Geological Survey (BGS) RockDrill2 [RD2] drill over the aft port side). In order to maintain station accuracy, the DP system ran for $\approx 15-20 \mathrm{~min}$ at each site to build a reliable DP model prior to operations. An ultra-short baseline beacon was attached to each drill, communicating with a transceiver on a pole that was lowered from the starboard side to $\approx 3.5 \mathrm{~m}$ water depth, giving an accurate hole position and water depth. Coordinates in this report refer to the beacon positions on the drills rather than the position of the vessel. Table T1 summarizes the distances between Expedition 357 holes and sites.
Figure F1. Expedition 357 drill sites overlain onto multibeam bathymetry acquired during the expedition (50 m resolution). Expedition 304/305 sites are shown for context.

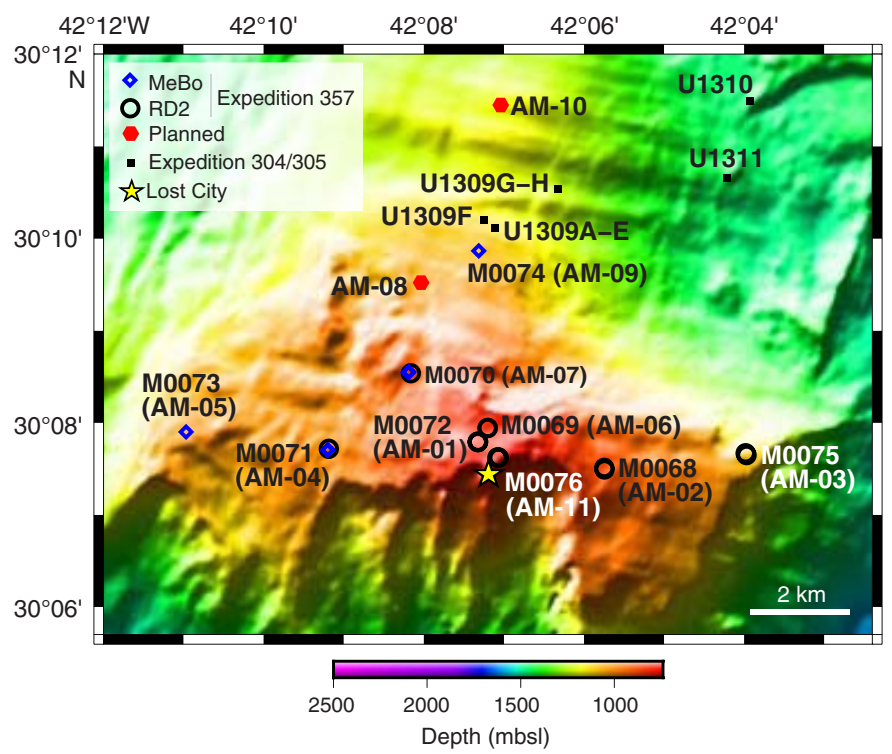

\section{Multibeam site surveys undertaken during the expedition}

Prior to coring operations, a multibeam echo sounder survey was conducted to accurately place the break of slope against two preexisting bathymetric data sets and the site locations. Multibeam

${ }^{1}$ Früh-Green, G.L., Orcutt, B.N., Green, S.L., Cotterill, C., Morgan, S., Akizawa, N., Bayrakci, G., Behrmann, J.-H., Boschi, C., Brazelton, W.J., Cannat, M., Dunkel, K.G., Escartin, J., Harris, M., Herrero-Bervera, E., Hesse, K., John, B.E., Lang, S.Q., Lilley, M.D., Liu, H.-Q., Mayhew, L.E., McCaig, A.M., Menez, B., Morono, Y., Quéméneur, M., Rouméjon, S., Sandaruwan Ratnayake, A., Schrenk, M.O., Schwarzenbach, E.M., Twing, K.I., Weis, D., Whattam, S.A., Williams, M., and Zhao, R., 2017. Expedition 357 methods. In Früh-Green, G.L., Orcutt, B.N., Green, S.L., Cotterill, C., and the Expedition 357 Scientists, Atlantis Massif Serpentinization and Life. Proceedings of the International Ocean Discovery Program, 357 : College Station, TX (International Ocean Discovery Program). http://dx.doi.org/10.14379/iodp.proc.357.102.2017

2 Expedition 357 Scientists' addresses.

MS 357-102: Published 4 February 2017 
Table T1. Distances (in kilometers) between holes, Expedition 357. Download table in .csv format.

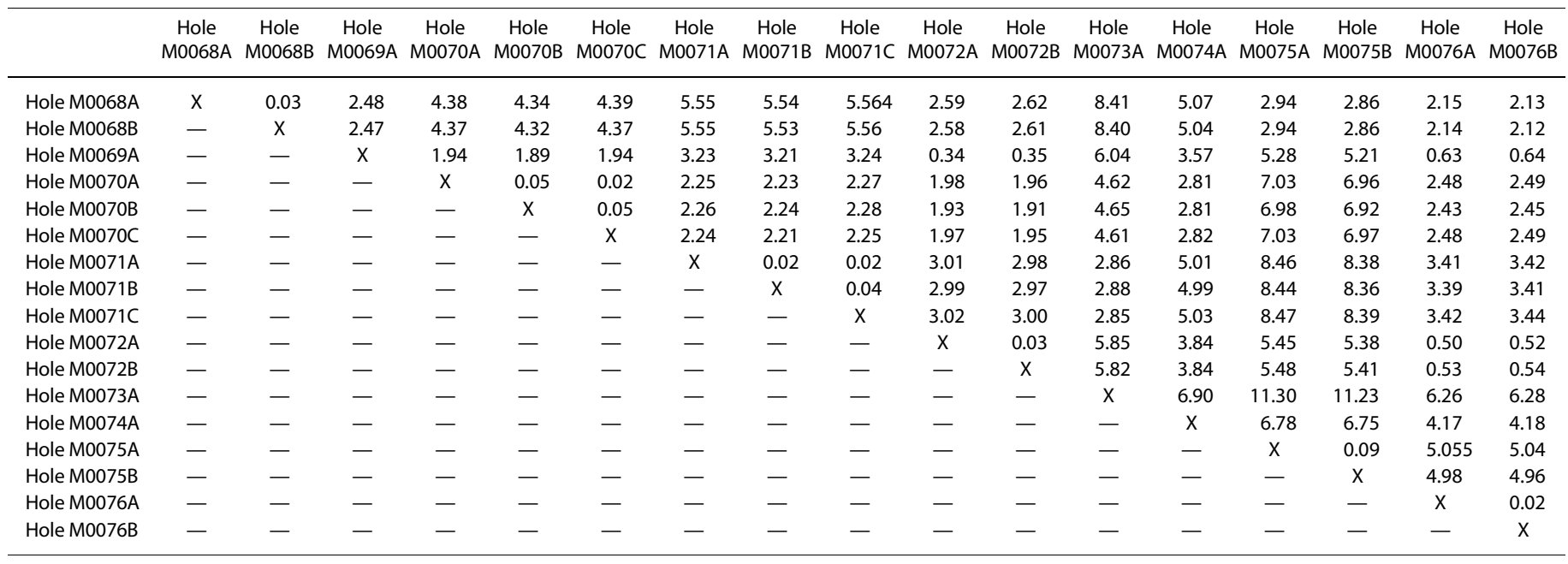

surveys were also conducted during down time and periods of bad weather when drilling operations could not be performed. The RRS James Cook operates a hull-mounted Kongsberg Simrad EM120 deep-sea multibeam echo sounder with an operating frequency of $12 \mathrm{kHz}$ and 191 beams. To improve resolution and analysis of slope angles at each drill site, the beam angle on the EM120 was decreased to $45^{\circ}$ from the normal $60^{\circ}$. EQANGLE (equal angle) beam spacing was used to improve the resolution in the central swath area, and $\mathrm{min} / \mathrm{max}$ depth settings were varied in an attempt to reduce the impact of outliers. In marginal weather conditions, seafloor detection was forced to only resolve below a certain depth (force depth) to assist with bottom detection. The combination of the above parameters gave a swath width approximately twice the water depth.

The sound velocity profile used was taken on 5 November 2015 and logged using the MIDAS sound velocity profiler (SVP) to 1009 $\mathrm{m}$ water depth. The sound speed transducer was set to "profile" for most of the multibeam survey. However, on 20 November, the transducer was set to "sensor" to utilize the surface sound velocities in marginal weather conditions. Heading, attitude, and positioning information were provided by the Seatex Seapath 200 positioning sensor. Sensor locations and offsets were all verified against the vessel's 2014 Blom Survey Report.

The survey lines allowed between $50 \%$ and $100 \%$ overlap with a survey speed of 5-6 kt. The combination of beam focusing, survey speed, and overlap percentages meant that a $50 \mathrm{~m}$ resolution surface could be generated within Caris HIPS and SIPS hydrographic survey software (version 9.1) to assess each location for slope prior to landing each rock drill. This procedure was later supplemented by further multibeam surveys over Atlantis Massif, the Atlantis Fracture Zone, the Mid-Atlantic Ridge, and some of the conjugate margin when all coring operations were suspended due to sea state. The swath settings used were the same as for the initial site surveys, with the vessel running at a speed between 5 and $6 \mathrm{kt}$ with variable line spacing dependent on depth. The surveys were run by either the vessel's system support technician or the Expedition Project Manager, depending on shift patterns. Initially, raw data were provided for use by the science party along with $50 \mathrm{~m}$ resolution geotiff metadata, with preliminary data cleaning undertaken by the vessel's system support technician. More detailed data cleaning was later undertaken by a marine geophysicist from the BGS at the request of the science party, removing anomalous data and outliers. This was done in Caris, generating fully cleaned $50 \mathrm{~m}$ and $20 \mathrm{~m}$ resolution per pixel surfaces and associated data sets:

- Cleaned x, y, z file,

- Fledermaus generated .sd file,

- Geotiff image, and

- ArcGrid ASCII file.

Because prior bathymetry of Atlantis Massif was acquired with a resolution of $>100 \mathrm{~m}$ per pixel, the new survey provides a much more detailed view of the tectonic, volcanic, and mass-wasting structures of the area (Figures F2, F3).

\section{Drilling platform}

\section{Operational equipment}

The maximum required depth of the boreholes was 70 meters below seafloor (mbsf), and water depth ranged between 720 and $1770 \mathrm{~m}$. Because of the scientific need to acquire good quality cores of the surface carbonate cap and hard rocks at depth and the potential to plug the boreholes to enable future observation, it was decided to utilize seabed drill technology. Therefore, a multirole oceanographic vessel and two seabed drills were selected to carry out Expedition 357 coring. The RRS James Cook, an $89.2 \mathrm{~m}$ long research vessel with DP capability (Figure F4), was donated as an "inkind" contribution from the UK's Natural Environment Research Council (NERC). The RRS James Cook has sufficient capacity by way of food and accommodation for $24 \mathrm{~h}$ operations for up to 50 days.

\section{Seabed drills}

Two seabed drill systems were utilized during Expedition 357: the BGS RD2 (Figure F5) and the Center for Marine Environmental Sciences (MARUM; Bremen, Germany) MeBo70 (Figure F6). Both drills are remotely operated systems that are lowered onto the seabed, with power and control maintained from the surface via an umbilical cable. The systems use multiple drill rods and core barrels to progressively penetrate into the seabed. They are both based on an HQ size coring system (rod outer diameter $[\mathrm{OD}]=88.9 \mathrm{~mm}$; rod inner diameter $=77.8 \mathrm{~mm}$; reaming shell diameter $=97.8 \mathrm{~mm}$ ) and produce $61.1 \mathrm{~mm}$ diameter cores collected in steel core barrels. The core diameter is similar to standard IODP cores, whereas the hole 
Figure F2. Multibeam data acquired over Atlantis Massif overlain with the vessel's navigation track plot, Expedition 357.

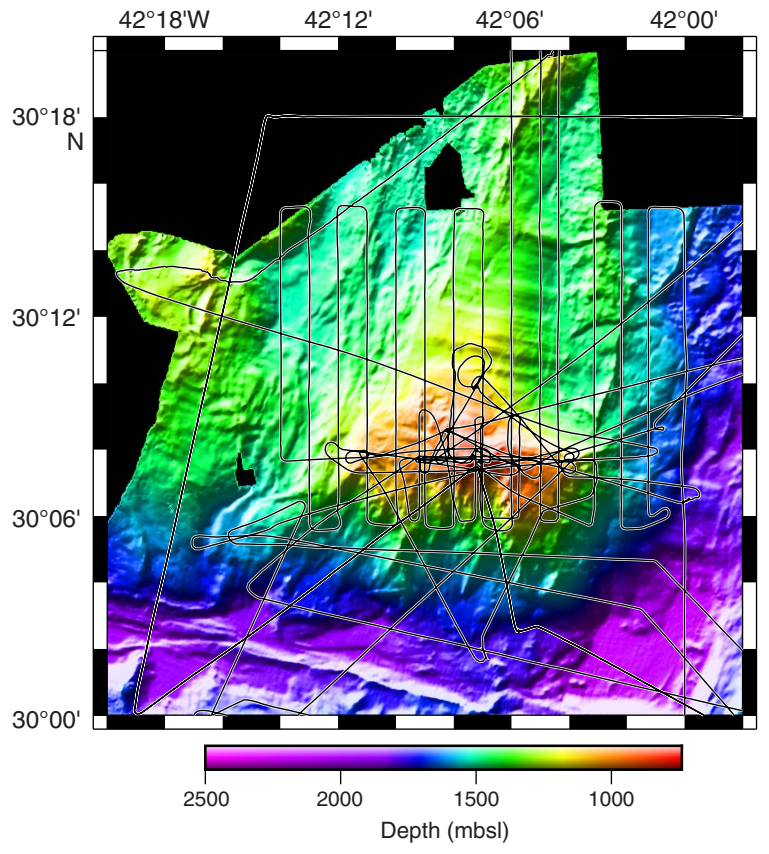

Figure F3. 3-D views of the multibeam data set gridded at $50 \mathrm{~m}$ resolution, Expedition 357.
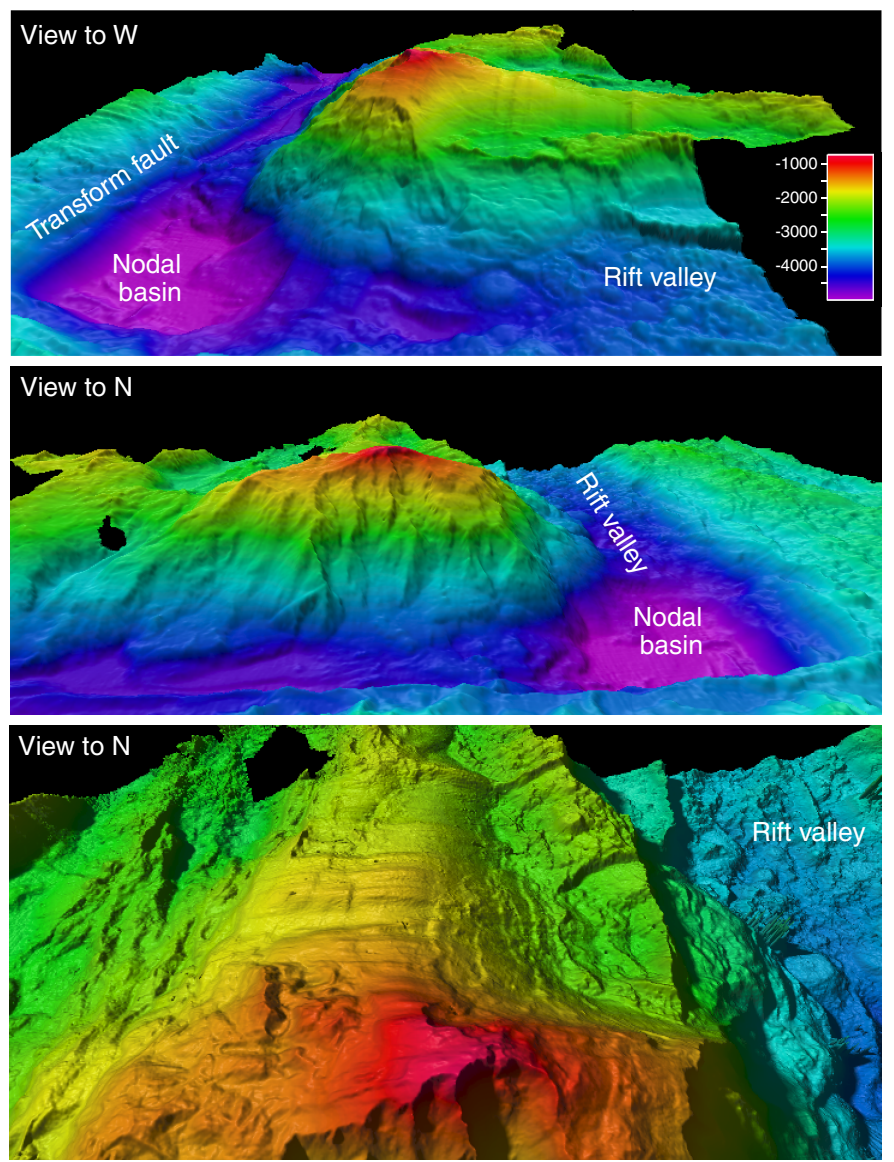

Figure F4. The RRS James Cook, the drilling platform for Expedition 357 provided by NERC as an in-kind contribution. Image courtesy of National Oceanographic Centre, Southampton (NOCS).

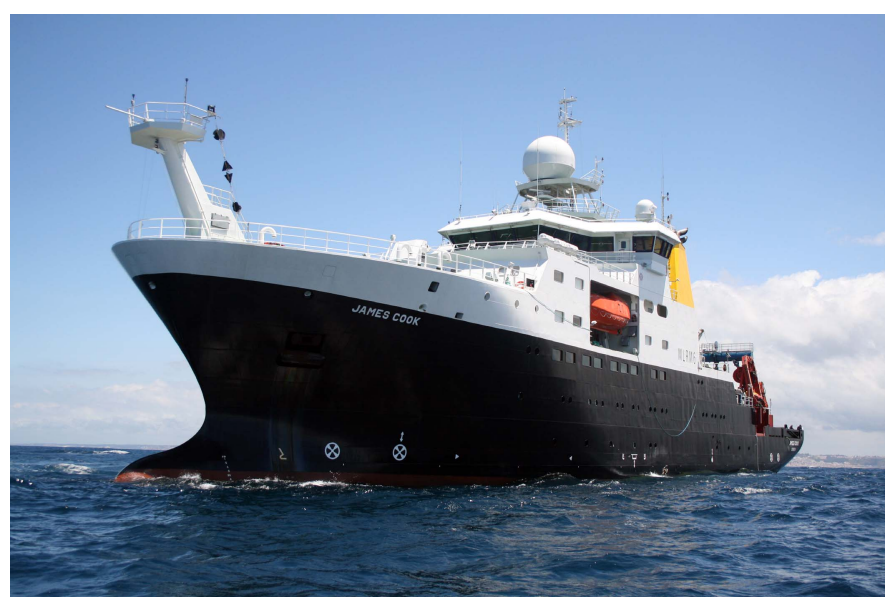

Figure F5. The BGS RD2 seabed drill deployed by its own LARS over the starboard side of the RRS James Cook, Expedition 357. Image courtesy of Dave Smith.

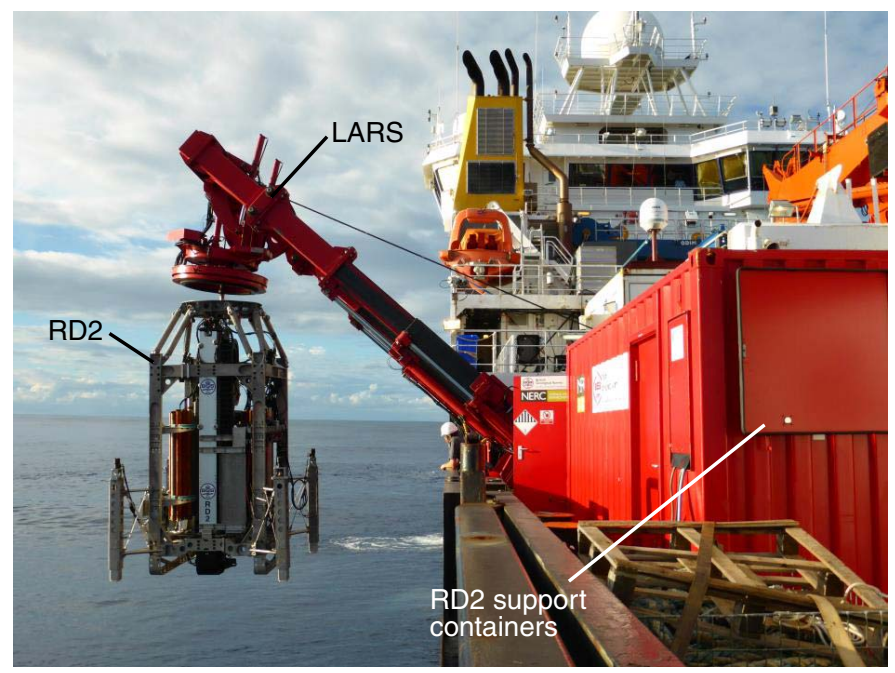

diameter, $98 \mathrm{~mm}$ (RD2) or $103 \mathrm{~mm}$ (MeBo), is narrower. By sitting on the seabed, the drills do not require heave compensation and consequently have good control on bit weight. These circumstances are analogous to land-based mine coring, where a thin-walled parallel drill string with a core barrel and liner is locked into an outer bottom-hole assembly (BHA) barrel. Each system has the capacity to operate with either a clear polycarbonate liner or stainless steel split liners.

The RD2 is a lightweight system (5 ton in water). It is a remotely operated multibarrel wireline drill capable of coring up to $55 \mathrm{mbsf}$ (Figure F5). Drill rods, core barrels, wireline logging tools (see Downhole logging), and borehole plug units (see Borehole plugs) are stored in tool racks. The maximum length that can be cored by each barrel is $1.72 \mathrm{~m}$. The RD2 is self-contained with its own Launch and Recovery System (LARS) and dedicated winch, occupying a basic deck footprint of $5 \mathrm{~m} \times 10 \mathrm{~m}$. The system additionally includes four $20 \mathrm{ft}$ containers (control, mechanical and electrical 
workshops, and spares). Launch and recovery is controlled wirelessly by one person. The RD2 has a maximum operating water depth of $4000 \mathrm{~m}$. Sensors on the drill enable the operator to monitor pitch and roll of the system and to inform adjustment of the extendable legs to achieve the requisite vertical position of the drill for operations. The top drive provides a maximum $405 \mathrm{rpm}$.

The MeBo (Figure F6) is a portable drill rig lowered to the seabed on a steel armored umbilical cable, allowing it to be remotely operated from a control cabin on the vessel. It weighs 7.5 tons (in water) and is capable of working in water depths up to $2000 \mathrm{~m}$. The drill has two rotating magazines that hold the drill rods, core barrels, wireline logging tools, and borehole plug units and can core to a maximum depth of 70 mbsf. It has four plate-like feet that can be individually adjusted to maintain the vertical position required for coring operations. Sensors, video cameras, and lights are used to monitor performance while on the seabed. The maximum length each core barrel can core is $2.5 \mathrm{~m}$. The top drive provides a maximum of $200 \mathrm{rpm}$. The complete MeBo LARS is mounted on a bed plate tailored to the vessel. During Expedition 357, the LARS required the use of the RSS James Cook's "A" frame (with a minimum capacity of 20 tons). Accompanying this are four $20 \mathrm{ft}$ containers (winch, control, workshop, and spares).

\section{Coring methodology}

To ensure flexibility during operations, a number of different drill bits were available for coring. The diamond cutting bit is on the outer BHA barrel, with an OD of $103 \mathrm{~mm}$ for the MeBo drill and 98 $\mathrm{mm}$ for the RD2 drill. Both drills maximized flexibility during drilling operations by deploying the drills with 2-4 BHAs, often with different bits installed, on each dive. The MeBo drill utilized 20/30 surface-set (Geogem) and G4 impregnated (DATC) bits. The RD2 drill utilized 30/40 surface-set (Geogem), 60/80 surface-set (Rock-

Figure F6. The MARUM MeBo70 seabed drill deployed from the stern of the RRS James Cook, utilizing the vessel's A-frame, Expedition 357. Image courtesy of Dave Smith.

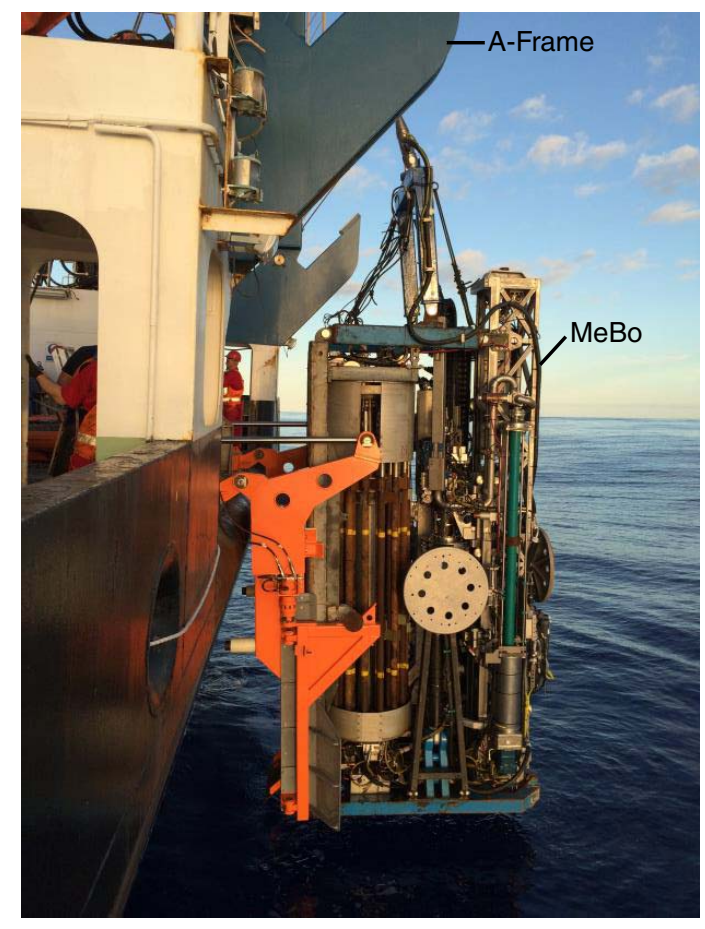

max), and G7 and G10 impregnated (Rockmax) bits. Seawater was the drilling fluid utilized in all holes, with no addition of muds.

Because rig floor and seafloor are effectively the same when using seabed drill technology, many of the IODP depth conventions are not appropriate (IODP Depth Scales Terminology at http://www.iodp.org/policies-and-guidelines). All depths are therefore reported as meters below seafloor.

\section{Additional developments}

The scientific drivers for IODP Expedition 357 required the development of several bespoke pieces of equipment designed or modified to be operated remotely from the seabed drills (FrühGreen et al., 2015):

- A water sensor/sampling package mounted on both seabed drills for monitoring in situ parameters and collecting water flushing out of the borehole (details available in Water sampling and sensor package data),

- A tracer injection system mounted on both seabed drills to inject perfluoromethylcyclohexane (PFC) into the drilling fluids to assess potential contamination of core materials (details available in Microbiology),

- Borehole plugs for sealing off drilled boreholes to prevent fluid circulation and enable future fluid sampling access (details available in Borehole plugs), and

- Wireline logging tools (details available in Downhole logging).

\section{Water column operations}

Before commencing drilling operations at each site, a cast of the ship's conductivity, temperature, and depth (CTD) Niskin rosette system was undertaken to capture a water column profile prior to coring and any associated disturbance (Figure F7). With bottom water a priority, three Niskin bottles were fired at the bottom of the cast, and one was fired near the surface (see Water sampling and

Figure F7. CTD rosette, RRS James Cook, Expedition 357. Image courtesy of Carol Cotterill.

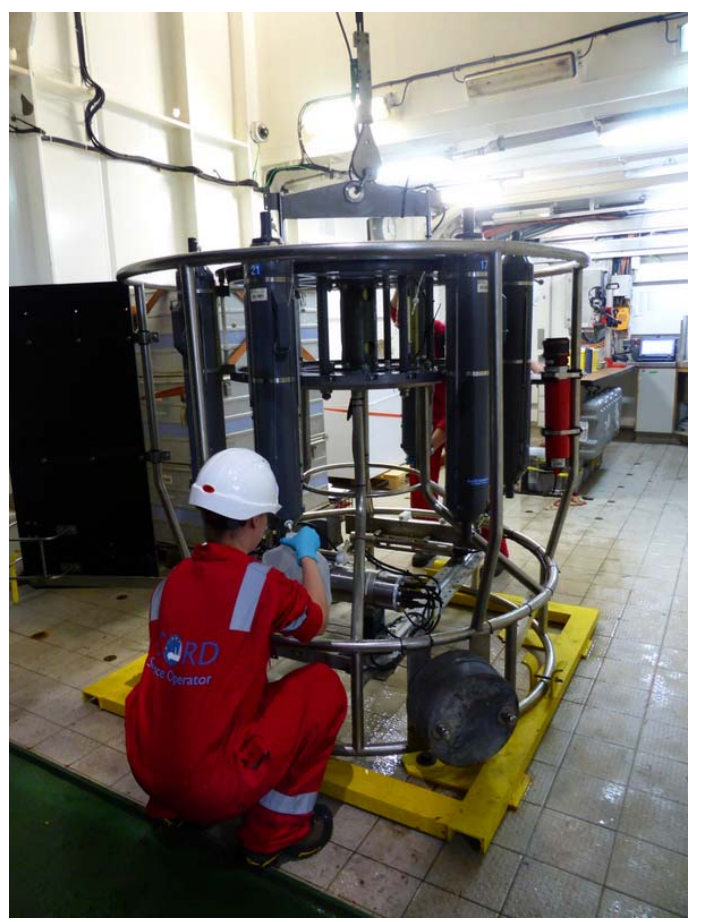


sensor package data). The other three Niskin bottles were fired at equal spacing in the water column. The CTD used on the RRS James Cook incorporated the following:

- 10 Niskin bottles (6 were used),

- Chelsea Technologies Group (CTG) AquaTracka MkIII fluorometer,

- CTG AquaTracka MkII transmissometer,

- Sea-Bird Electronics (SBE) 43 dissolved oxygen sensor,

- Benthos 916T altimeter,

- SBE 3P primary and secondary temperature sensor,

- SBE 4C primary and secondary conductivity sensor,

- Digiquartz pressure sensor, and

- WETLabs BBRTD light scattering sensor.

In addition to the site-related CTD casts, a deeper cast was conducted in the Atlantis Fracture Zone to $4135 \mathrm{~m}$ water depth, and another was conducted in the Mid-Atlantic Ridge to $4221 \mathrm{~m}$ water depth. The purpose of these casts was to provide baseline geochemistry readings at sites located away from Lost City and any possible venting of methane or hydrogen.

The ship's crew deployed the CTD, firing the Niskin bottles according to a depth schedule provided by the offshore Science Party members. Sensor data were recorded in the Sea-Bird Seasave (v7) software package, and the processed data were exported as $\mathrm{CNV}$ and ROS files.

\section{Shipboard scientific procedures \\ Numbering of sites, holes, cores, and samples}

Expedition numbers for IODP expeditions are sequential, starting with 301. Drilling sites are numbered consecutively, and for a European Consortium for Ocean Research Drilling (ECORD) Science Operator (ESO)-operated platform, numbering starts with Site M0001 (the "M" indicates the ESO-operated mission-specific platform [MSP]). For Expedition 357, the first site was Site M0068. Multiple holes may be drilled at a single site, with the first hole assigned the site number with the suffix "A," the second hole the site number and the suffix "B," and so forth. For sites where coring was not conducted but CTD casts were undertaken, the suffixes " $X$ " and "Z" were applied.

The cored interval is measured in meters below seafloor as measured by the drilling apparatus. For Expedition 357, the cored interval consisted predominantly of the entire drilled section, with only one hole (M0072B) having a short open-hole section of $0.825 \mathrm{~m}$. Recovered core is cut into sections with a maximum length of $1.5 \mathrm{~m}$ and numbered sequentially from the top, starting at 1 (Figure F8). By convention, material recovered from the core catcher is treated as a separate section labeled "CC" (core catcher) and placed below the last section recovered in the liner. The core catcher is assigned to the top of the cored interval if no other material is recovered. When recovered core is shorter than the cored interval, the top of the core, by convention, is equated to the top of the cored interval to achieve consistency in reporting the depth in core.

Any sample removed from a core is designated by distance measured in centimeters from the top of the section to the top and bottom of the sample removed. A full identification number for a sample consists of the following information: expedition, site, hole, core number, core type, section number, piece number (for hard rock), and interval in centimeters measured from the top of section. For example, a sample identification of "357-M0069A-3R-2, 35-40 $\mathrm{cm}$," represents a sample removed from the interval $35-40 \mathrm{~cm}$ below the top of Section 2, Core 3R (" $R$ " indicates core type; see be-
Figure F8. IODP depth and naming conventions, Expedition 357. CC = core catcher.

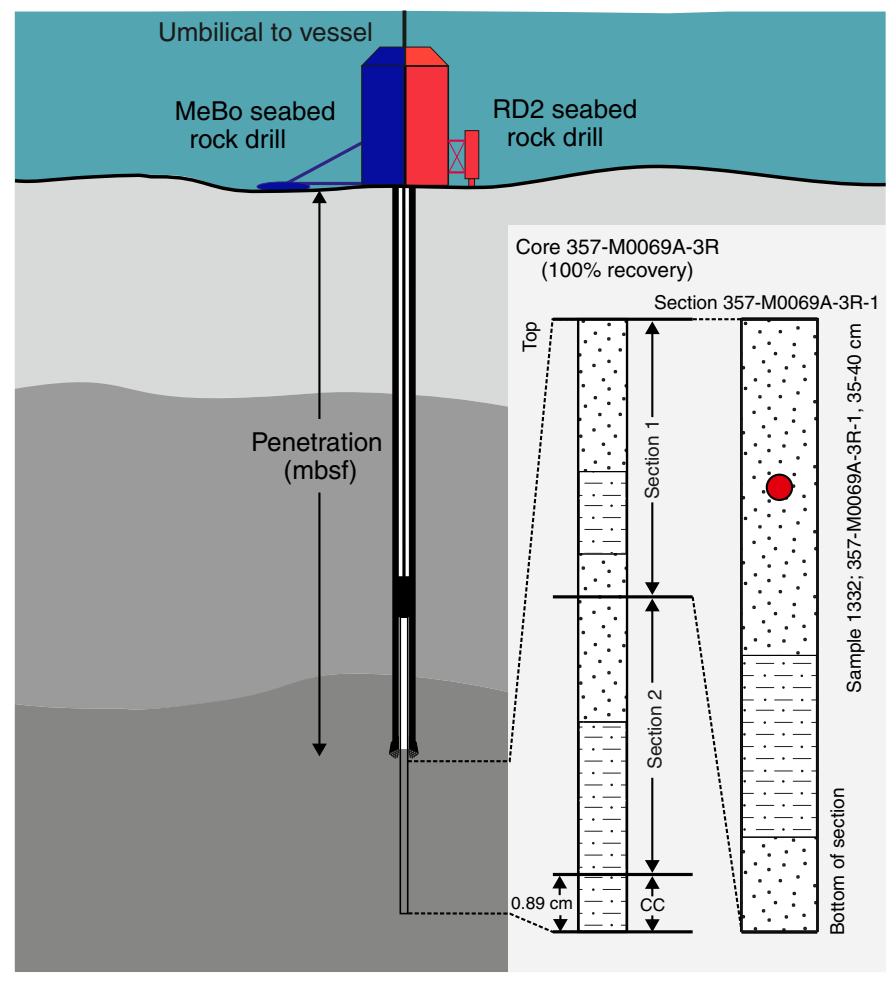

low), from Hole M0069A during Expedition 357 (Figure F8). All IODP core identifiers indicate core type. For Expedition 357, the following abbreviations are used:

- $\mathrm{O}=$ noncoring assembly/open hole.

- $\mathrm{R}=$ rotary coring.

The meters below seafloor of a sample is calculated by adding the depth of the sample below the section top and the lengths of all higher sections in the core to the core-top datum measured with the drill rods.

\section{Core handling during the Expedition $\mathbf{3 5 7}$ offshore phase}

Because Expedition 357 utilized seabed drills, all core material arrived on deck at the same time. It was therefore necessary to modify the usual IODP core flow to accommodate this novel sampling scheme, which is illustrated in Figure F9. Because of the ephemeral nature of the microbiology and geochemistry samples (see Microbiology and Geochemistry), it was decided that the deepest core would be the first to be unloaded from the drill tool racks and delivered to core curation and sampling because it had been in the core barrel for the least amount of time and represented the most pristine sample. Subsequently, each core barrel, working from deepest to shallowest in the hole, was removed from the tool racks and delivered to the curation bench. Plastic "tags" were clipped onto each liner removed from the core barrels identifying the core run number to prevent confusion from working in reverse order. To prevent cores from warming up, they were temporarily stored in a $+4^{\circ} \mathrm{C}$ temperature-controlled reefer if they could not be immediately curated. As the core barrels were unloaded from the drill tool racks, liner fluid was collected for PFC tracer, cell counts, and organic acids analyses. 
As soon as a core was removed from the core barrel, it underwent preliminary curation by the ESO curators and was cut into maximum $1.5 \mathrm{~m}$ length sections. Where metal splits were used instead of polycarbonate liner, the core was transferred from the splits into polycarbonate liner by the curators prior to marking and cutting the cores into sections. Each section was sealed at the top and bottom by a color-coded plastic cap in line with IODP convention: blue for the top of a core section, white for the bottom, and yellow where a whole-round core (WRC) sample for microbiology was removed. The core lengths in each section were entered into the Offshore Drilling Information System (OffshoreDIS). No core splitting took place during the offshore phase of the expedition.

\section{Curation procedures and core processing}

Because the deepest core was anticipated to have changed the least with respect to the microbial communities, a WRC was taken prior to any further curation or nondestructive analyses (see Microbiology). The WRC was photographed to document removed material. Core sections were then transferred to a fast-track multisensor core logger (MSCL) on which high-resolution $(2 \mathrm{~cm})$ magnetic susceptibility data were acquired without allowing any time for temperature equilibration of the cores (see Physical properties). After the fast-track MSCL, for the second deepest core and every other core moving uphole, a WRC was taken for later microbiology subsampling (see Microbiology). Next, all core section liners were permanently labeled with an engraving tool. The shipboard petrologist made a brief description of the core recovered through the clear plastic liner. Cores were allowed to equilibrate to ambient temperature in the petrophysics laboratory before being measured on the standard MSCL (MSCL-S) with a measurement resolution of $2 \mathrm{~cm}$ (see Physical properties). Following this, a small thin section

Figure F9. Core flow for the offshore phase of Expedition 357. Not every sample is taken from every water sensor package/CTD cast. $\mathrm{POC}=$ particulate organic carbon.

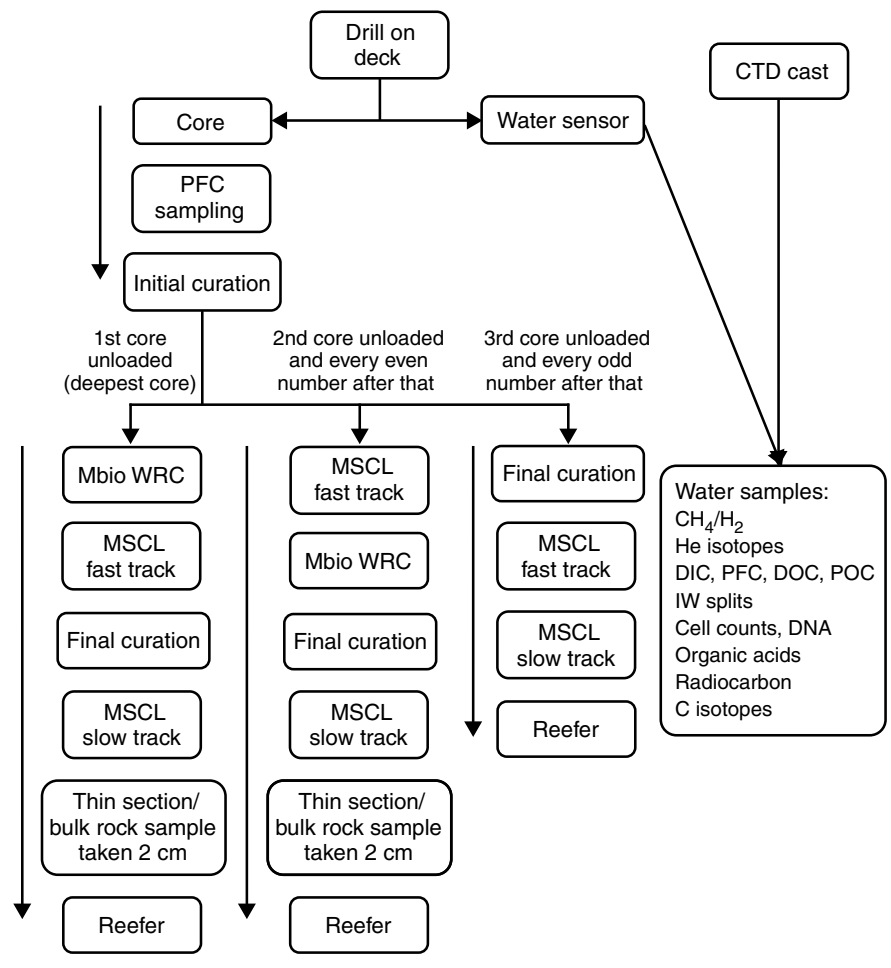

billet was cut for thin sectioning and bulk rock characterization. The cores were then transferred to a $+4^{\circ} \mathrm{C}$ temperature-controlled reefer for shipping back to the IODP Bremen Core Repository (BCR; Germany).

\section{Curation procedures and core processing for sediment cores}

For sediment cores, initial sampling of liner fluid and full curation of the core into sections (including permanent labeling of sections through engraving) was completed, and the sections were then measured on the fast-track MSCL. Windows were then cut into the liner at specific points for syringe microbiological sampling and insertion of Rhizons for interstitial water (IW) sampling. The shipboard petrologist made a brief description of the core recovered through the clear plastic liner, and the cores were then measured on the MSCL-S and stored in the reefer, as described above.

\section{Core handling during the Expedition 357 Onshore Science Party}

The OSP was held at the BCR from 20 January to 5 February 2016. The onshore core flow is summarized in Figure F10. Prior to the OSP, and hence before splitting, all cores were measured for natural gamma radiation (NGR) and underwent $360^{\circ}$ through-liner high-resolution digital line scanning (see COREDESC in Supplementary material; see Physical properties).

After removal from refrigerated storage, cores were described through the liner by the structural, igneous, and metamorphic petrologists using the $360^{\circ}$ scans as a guide (see Core description). Once this preliminary description was completed, the line-scan im-

Figure F10. Core flow for the onshore phase of Expedition 357.

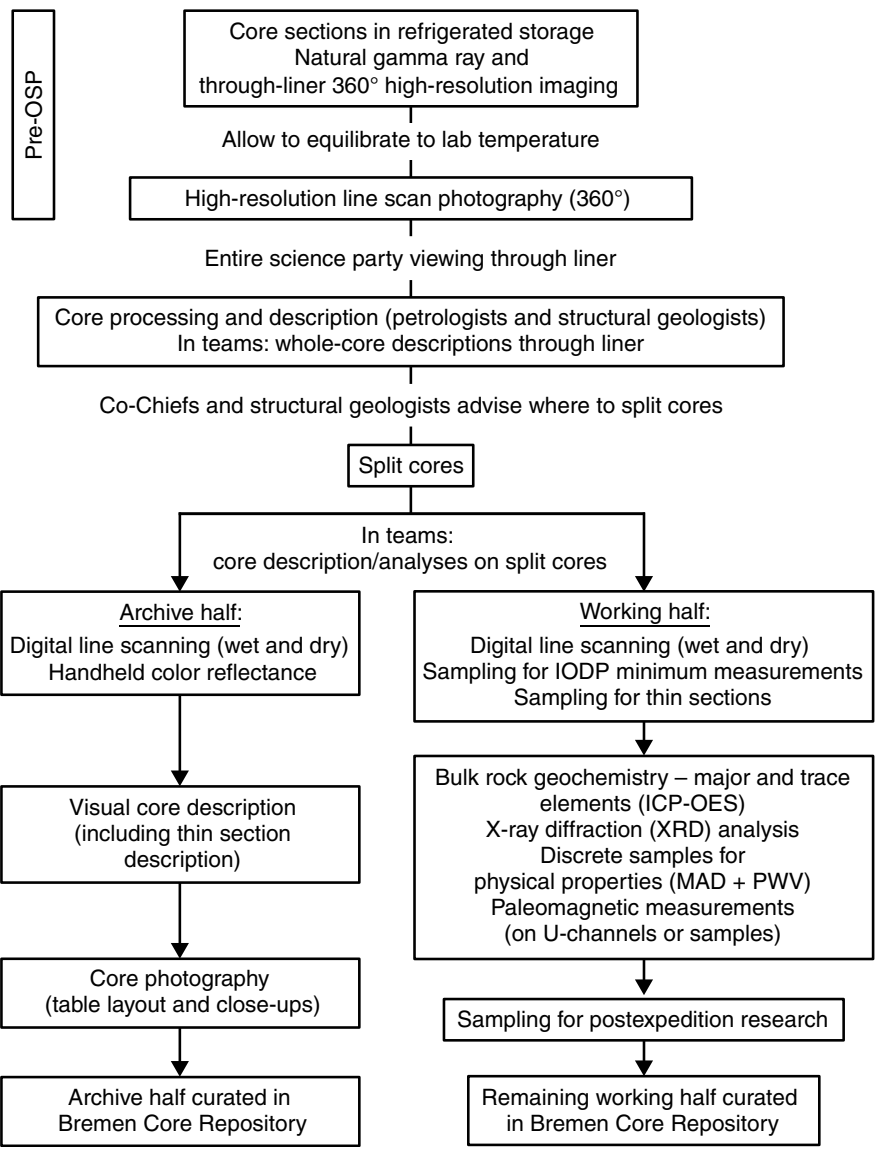


ages were marked up by the structural geologists to indicate the preferred orientation for core splitting. The cores were split lengthwise into working and archive halves from top to bottom.

The working and archive halves were taken for high-resolution digital line scanning, both wet and dry, followed by color reflectance spectrophotometry measurements on the archive halves. The archive halves were then described by the structural, igneous, and metamorphic petrologists aided by thin sections (see Core description), including the preferred locations for shipboard sampling, to ensure comprehensive coverage of all lithologies and structural features. Following description, archive halves were wrapped in polyethylene (PE) stretch film and put back into the core repository reefer.

On completion of core description, the working halves were sampled, following a Sample Allocation Committee (SAC) meeting to agree on sample locations. The first samples taken were for IODP minimum measurements, including paleomagnetism analysis on discrete cubes, physical property measurements $(P$-wave and moisture and density $[\mathrm{MAD}])$, X-ray diffraction (XRD), and bulk rock measurements (see Physical properties, Paleomagnetism, Geochemistry, and Core description). Analyses were conducted on samples taken offshore, as were total carbon (TC)/total inorganic carbon (TIC) measurements (see Geochemistry). Additionally, standard geochemical measurements were performed on fluid samples collected during the offshore phase.

Following these measurements, sampling for postexpedition research was undertaken, following review by the entire science party. Locations for preferred samples were indicated using stickers, and these were reviewed by the SAC prior to postexpedition sampling. The working halves were then wrapped and moved to the core repository reefer. Each sample taken was logged into the Expedition Drilling Information System (ExpeditionDIS).

\section{Data handling, database structure, and access}

Data management during the offshore and onshore phases of Expedition 357 had two stages. The first stage was the capture of metadata and data. Central to this was the ExpeditionDIS, which stored information about drilling, core curation, sampling, and primary measurements. The second stage was the longer term postexpedition archiving of Expedition 357 data sets, core material, and samples. This function was performed by the World Data Center for Marine Environmental Sciences (PANGAEA) and the BCR.

The ExpeditionDIS is a flexible and scalable database system originally developed for the International Continental Scientific Drilling Program (ICDP) and adapted for ESO. The underlying data model for the ExpeditionDIS is compatible with those of the other IODP implementing organizations. For the specific expedition platform configuration and workflow requirements of Expedition 357, the ExpeditionDIS data model, data import pumps, and user interfaces were adapted to form the Atlantis Massif ExpeditionDIS (DIS Version 6). This also involved some new functionality, including the set-up of predefined series for quicker entry of microbiology samples, interstitial water subsamples, and CTD water samples.

The ExpeditionDIS was implemented in SQLServer-2008 R2 installed on a central server with Microsoft-based client PCs connecting to the system through a Microsoft Access 2010 user interface. The work on DIS development is carried out by Smartcube GmbH.

Offshore, the ExpeditionDIS was used to capture metadata related to core and sample curation and downhole logging, store core catcher and WRC sample photographs, and to print section, sample, and subsample labels. During Expedition 357, Niskin water samplers with CTD were used to collect water samples prior to drilling (standard CTD) and during drilling (sensor package). The metadata from these tools and resulting samples were also captured in the ExpeditionDIS. Additionally, the database stored primary measurement data:

- MSCL data (both MSCL-S and fast-track MSCL) and

- Visual core descriptions (VCDs) of core catcher material, core sections (through liner), and WRC samples taken for microbiology.

The expedition scientists and ESO staff generated a variety of spreadsheet files, text documents, and graphics containing operational and scientific data, geological descriptions, and interpretations. Therefore, in addition to the structured metadata and data stored in the ExpeditionDIS, all data files were stored in a structured file system on a shared file server. Full backups of the server were made twice daily, incremental backups were made continuously, and the main server was also replicated on the backup server. The European Petrophysics Consortium was responsible for the capture and processing and archive of the downhole logging data (see Downhole logging).

On completion of the offshore phase of the expedition, the ExpeditionDIS database and file system were transferred to the BCR to continue data capture during the OSP. On shore, additional data were captured in the ExpeditionDIS, including samples, thin section scans, thin section photomicrographs, core close-up images, high-resolution line-scan images (for both through-liner and split cores), color reflectance data, thin section data, NGR data, and full VCDs of split cores. All other data were loaded to the shared file server.

During the onshore phase, line-scan images were viewed in the core description laboratory across three screens using the Corelyzer Corewall application.

After the expedition, the sampling and core curation data were exported from the ExpeditionDIS to CurationDIS, the long-term BCR core curation system.

During the second stage, all Expedition 357 data were transferred to the PANGAEA information system. PANGAEA is a member of the International Council of Scientific Unions World Data Centre system. It has a flexible data model that reflects the information processing steps in earth science fields and can handle any related analytical data (Collier, 2015; Diepenbroek et al., 1999, 2002). It is used for processing, long-term storage, and publication of georeferenced data related to earth sciences. Essential services supplied by PANGAEA are project data management and distribution of visualization and analysis software. Data management functions include quality checking, data publication, and metadata dissemination that follows international standards.

The data captured in the Atlantis Massif ExpeditionDIS and the data stored on the shared file server were transferred to PANGAEA following initial validation procedures. The data transfer process was completed by the time of publication of the expedition reports section of this Proceedings of the International Ocean Discovery Program volume. Until the end of the moratorium period, data access was restricted to the expedition scientists. Following the moratorium, all data except downhole wireline data were published online (http://www.pangaea.de), and PANGAEA will continue to acquire, archive, and publish new results derived from Expedition 357 samples and data sets. Downhole wireline data were archived at http://brg.ldeo.columbia.edu/logdb with a link from PANGAEA. 
IODP MSP data are also downloadable from the MSP data portal at http://iodp.pangaea.de.

\section{Core, section, and sample curation using the Atlantis Massif ExpeditionDIS}

Expedition 357 followed IODP protocols and naming conventions (see Numbering of sites, holes, cores, and samples). The ExpeditionDIS captured the curation metadata and printed the appropriate labels, also to IODP standards. The curation metadata comprise

- Expedition information,

- Site information (latitude, longitude, water depth, start date, and end date),

- Hole information (hole naming by letter, latitude, longitude, water depth, start date, and end date),

- Core information (core number, core type, top depth, bottom depth, number of sections, core catcher availability, curator on shift, time and date for core on deck, and any additional remarks),

- Section data (section number and length, curated length, and curated top depth),

- Sample information (repository, request number, code observer, expedition, site, hole, core, section, half, sample top and sample bottom, and sample volume),

- Calculated core recovery percentage (on the basis of drilled or cored length versus curated recovery), and

- Calculated section recovery (on the basis of section length versus curated recovery).

\section{Core description}

Core material from Expedition 357 was subject to description during both the offshore and onshore phases. As is standard for MSPs, cores were not split offshore but were cut into sections (see Introduction). Recovery was variable, and cores exhibited drillinginduced fracturing in some intervals. However, numerous intact and continuous sections of core were recovered, which indicated that significant drilling-induced rotation had not occurred, and those cores preserve the relative orientation of veins, contacts, and other structures.

Macroscopic and petrographic core observations made during the offshore and onshore phases of Expedition 357 are stored in handwritten and electronic media (see COREDESC in Supplementary material). Preliminary lithologic descriptions were made offshore by the Co-Chief Scientists on microbiology whole-round samples and on the remaining WRCs through the plastic liners. In some cases, photographs were taken of cores through the liner with a handheld camera. These photographs were provided to the science party prior to the onshore phase of the expedition. At the OSP, detailed rock descriptions and measurements of the cores through the liners followed by descriptions on split cores were made by teams assigned to three disciplines: igneous petrology, alteration petrology, and structural geology.

At the OSP, observations and measurements were carried out on the archive halves of the cores, except where otherwise noted. All observations and measurements for each site were recorded on IODP VCD forms (see COREDESC in Supplementary material; see Core descriptions) and entered as input variables in the ExpeditionDIS. Observable parameters in the ExpeditionDIS were fixed drop-down menu items, free text, and predefined value lists of mineralogy and features related to structure, veins, and fractures.

\section{Offshore visual core description}

During the offshore phase of Expedition 357, general lithology, structure, lithologic contacts, major vein generations, and crosscutting relationships were summarized using preliminary descriptive terminology and definitions and a simplified version of the VCD form. When possible, macroscopic descriptions were confirmed with observations on small fragments of the core using a binocular microscope. Samples taken offshore for microbiology were photographed on two sides where possible (see MBIOWRC in Supplementary material) and briefly described. Microbiological samples taken on board have the notation "MBio." Where microbiology samples were taken from intervals of coherent rock, 2-5 cm slabs were cut for OSP thin section and bulk rock analyses.

\section{Onshore visual core description Though-liner descriptions}

Prior to the OSP, NGR was measured on the unsplit cores, and through-liner digital images were taken of the outside of each core, rotated $90^{\circ}$ with each pass (four in total for each core section), covering the whole circumference (see Physical properties). Because of the heterogeneity of the cores, a preliminary description was conducted prior to splitting to determine the most appropriate axis for cutting the cores. The preliminary description included rock type, metamorphic alteration, and structures through the liner, recorded on A2-sized prints of the core line scans (see COREDESC in Supplementary material). The desired cutting line was drawn in red wax pencil on the liner and the printed image. Core were split, initially keeping the two sides together, and then carefully separated into archive and working halves. The cut core was curated, and the archive half was described following the methods explained below (Figure F10).

\section{Cut-core descriptions}

During the onshore phase of Expedition 357, detailed macroscopic descriptions of lithology, alteration features, structures, and major vein generations and crosscutting relationships were recorded by hand on A3-sized VCD forms that included scanned split-core images (see COREDESC in Supplementary material). Two teams of petrologists and structural geologists working in shifts described the igneous petrology, metamorphic petrology, and structural features of all cores and thin sections. Each team was assigned shifts that provided time and space to examine the cores and ensure overlap with the other team for information exchange. At the beginning of the OSP, each expertise group agreed on descriptive terminology and definitions for each type of measurement, which were summarized in classification diagrams and glossaries. After core descriptions were complete, the petrological and structural data were entered as input variables in the ExpeditionDIS and recorded in logs as Microsoft Excel spreadsheets (see COREDESC in Supplementary material).

\section{Classification and description criteria}

A summary of the lithologies, line-scan images, core recovery, and most pertinent macroscopic features in each hole are represented graphically in the compiled VCDs (see Core descriptions). VCD information was plotted as symbols, patterns, and line plots against depth using the commercial plotting program Strater. An example of a VCD is shown in Figure F11, and a summary of the legend used for lithologic units and alteration types used in the sheets is given in Figure F12. Tabulated section data were extracted from the ExpeditionDIS or Excel spreadsheets. The locations of 
Figure F11. Example of a compiled VCD form that summarizes dominant lithologies, alteration features, and structure logged in each hole, Expedition 357 . See Figure F12 for explanation of color scheme, symbols, and abbreviations.

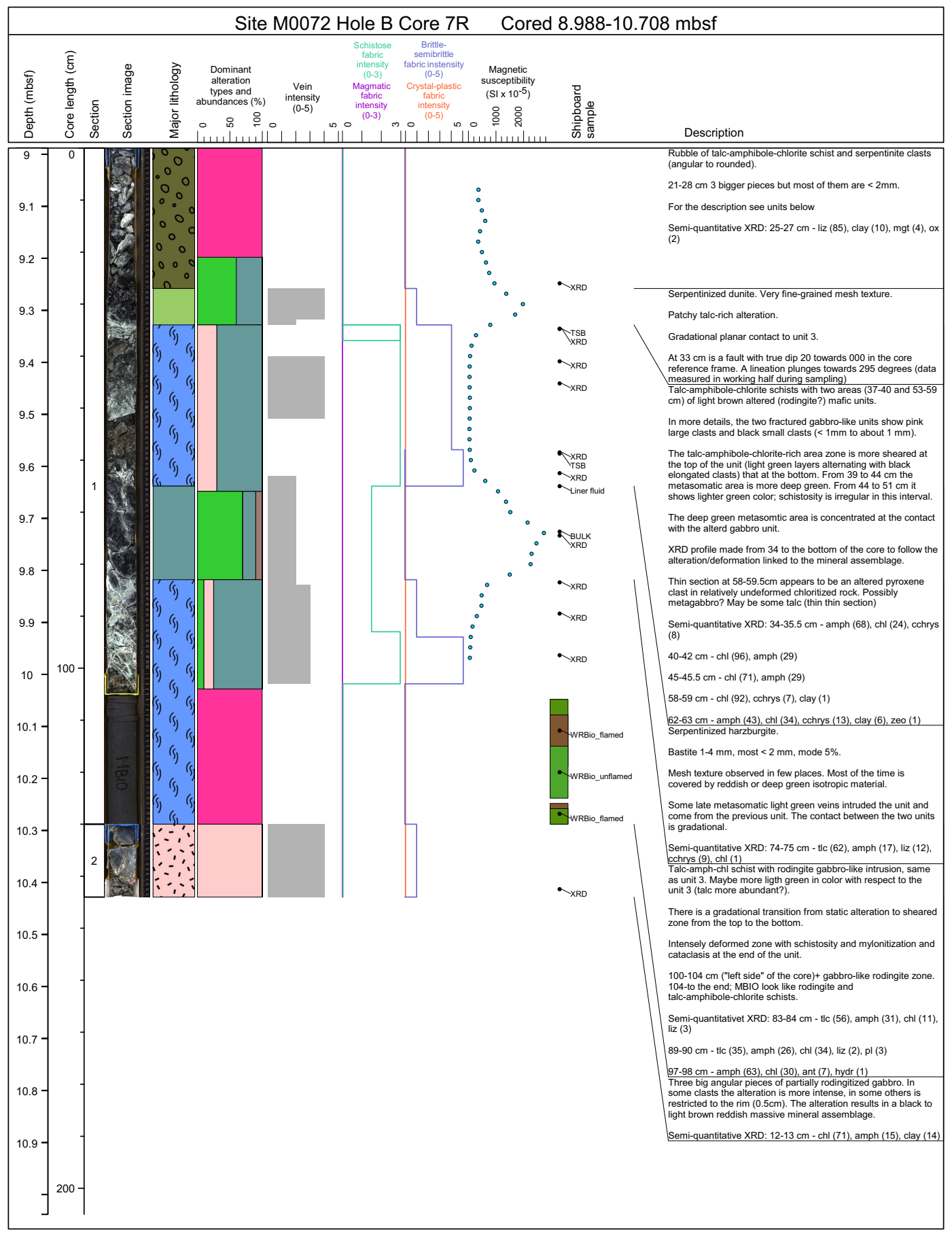

samples taken for microbiology and onshore analyses are noted in the Shipboard samples column. Complete macroscopic descriptions and measurements are available for each site in the VCDs and in the igneous, metamorphic, and structural core logs (see COREDESC in Supplementary material). Microscopic descriptions on petrographic thin sections were made on selected samples at each site and recorded in thin section logs as Excel files (see COREDESC in Supplementary material). The science party also selected key intervals for shipboard XRD and bulk rock analyses.
Interval descriptions and lithologic units

Lithologic characterization was based on the homogeneity of intervals recovered within a section of core. If sequential intervals and pieces were homogeneous with respect to magmatic or alteration features, they were combined into one lithologic unit and described macroscopically in the corresponding ExpeditionDIS input form. Lithologically and texturally similar pieces or intervals from consecutive core sections were curated as the same lithologic unit. If a contact (e.g., change in primary mineralogy, color, grain size, or 
Figure F12. Lithologies, symbols, and abbreviations used in VCDs, Expedition 357.

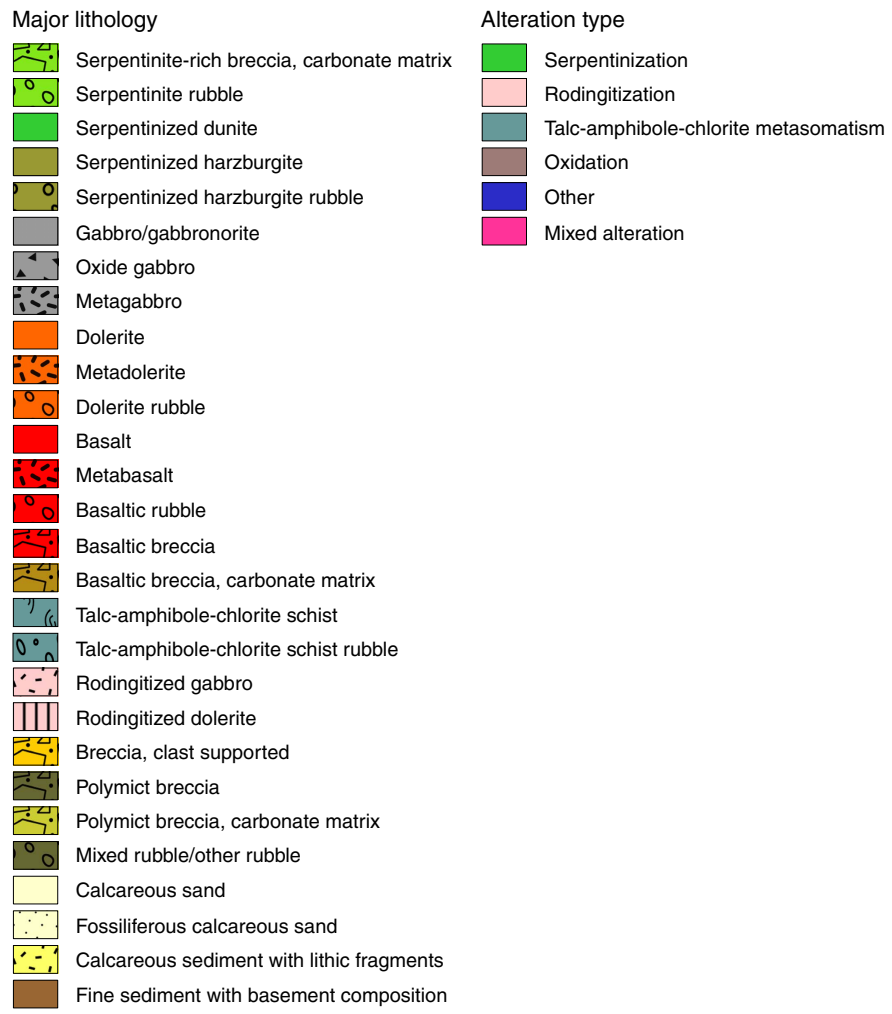

structural or textural variation) was recognized within a given piece or interval, a new lithologic section unit was defined and described. In this way, all important lithostratigraphic information was preserved on a truly descriptive basis. Where contacts and/or boundaries deviated from horizontal within the core reference frame, their depths were logged on the right-hand side of the cut face of the archive half when viewed upcore. A summary of the lithologic units, including the description of the lithologic contacts, was logged into the corresponding ExpeditionDIS section unit input form. Subdivisions were occasionally defined for specific intervals where subtle changes in lithology occur over short intervals (e.g., grain size and modal abundance of principal phases).

Based on the description of lithologic intervals and their contacts, coherent rock type units were defined on a broader, more interpretative scale after discussions with the entire scientific party. Description, characterization and explanations, and reasoning for combination of lithologic units are summarized for each hole separately in the Lithology, alteration, and structure section of each site chapter. Entries into ExpeditionDIS include each lithologic interval; core, section, interval; interval depth (in mbsf) of top and bottom; piece numbers; complete lithologic name (of the principal lithology and modifiers, if used); and description of the contacts. Average grain sizes and modal contents of the principal minerals for individual intervals can be obtained from the VCDs (see Core descriptions).

Contacts between lithologic intervals and units Distinctions between lithologic units include the following:

- Contact nature: sharp, gradational, and sutured (contacts where individual mineral grains interlock across the contact).
- Contact geometry: planar, curved, or irregular.

- Degree of deformation and relationship to bounding units: sheared, foliated, diffuse, or fractured.

\section{Dikes/veins}

The term "dike" refers to any sharp, well-defined, and relatively thick $(>1 \mathrm{~cm})$ crosscutting feature formed by injection of magma. This contrasts with "igneous vein," which describes a thin $(<1 \mathrm{~cm})$ crosscutting feature formed by injection of magma with generally less well defined contacts. Dikes were generally designated as individual intervals, whereas igneous veins were typically designated as subintervals or noted within the section description. Igneous veins are described in Igneous protoliths and petrology; veins that are mineralized fractures and their infilling mineral phases and textures are described in Alteration and metamorphic petrology.

\section{Core disturbances}

Seabed drilling during Expedition 357 produced relatively continuous sections of core that often preserve primary relationships between lithologic units and veined intervals. However, drilling often resulted in fracturing and core disturbance. The following categories of core disturbances were recorded as a comment in the ExpeditionDIS:

- Undisturbed.

- Slightly disturbed: possible core rotation and cracking.

- Moderately disturbed: partial fracturing.

- Highly disturbed: fragmented framework and fractured intervals.

- Rubble: drilling-induced strong fragmentation and formation of rubbly pieces.

- Soupy: water-saturated intervals that show loss of cohesion.

\section{Lithologies}

\section{Sediment, breccia, and rubble}

At a number of sites, sediment cores were collected at the top of the massif, which can provide information about the timing and tectono-depositional history after the surface of the massif was exposed on the seafloor. Sediment components were described offshore on simplified VCD forms, but no detailed lithostratigraphy was determined. Distinctions were made according to sediment type, degree of lithification, and composition and structure of detrital components. The sedimentary sequences include the following:

- Unconsolidated calcareous ooze or sand, commonly with abundant foraminifers.

- Variably lithified, fossiliferous calcareous sediment with lithic fragments and commonly with abundant foraminifers. The lithic fragments occur in varying amounts and have varying lithologies, angularity, and sizes.

- Breccias with varying amounts and composition of fossiliferous carbonate matrix and varying lithologies, angularity, and sizes of the lithic fragments. These can be matrix supported or clast supported.

The cores also comprised several intervals of the following:

- Fine sandy to gravelly sediment with basement composition. Their origin is unknown but may be attributed to drilling-induced fragmentation. We recorded the lithologic nature, angularity, and sizes of lithic fragments, as well as the color and, if possible, the composition of the finer grained material.

- Polymict breccia with subangular to angular clasts of serpentinite, metagabbro, and metadolerite in a carbonate matrix. 
The origin of these breccias was subject to discussion: (1) sedimentary in origin with a matrix lacking obvious foraminifers or (2) tectonic in origin with extensive posttectonic carbonation of a finely grained cataclastic matrix. In several instances, this question was answered with the observation of thin sections.

\section{Igneous protoliths and petrology}

For consistency, qualitative measurements including unit contacts and lithologic variations were discussed between the igneous petrologists during each shift crossover. The rocks recovered during Expedition 357 were generally moderately to highly altered but in many cases preserved igneous precursor textures. Igneous units were defined on the basis of estimates of primary igneous rock types and textures. Where primary textures were preserved, mineral modes were estimated visually (after Compton, 1962). Subintervals with subtle variations or sharp changes in grain size and/or mode on a centimeter scale were grouped into a single lithologic unit. If significant, minor variations within a unit were described in the text of the hard rock VCDs and entered into the ExpeditionDIS. Mineral habits, igneous structures, and igneous fabrics were also recorded, as well as the nature of igneous contacts. Details of individual measurements are given below.

\section{Primary minerals}

In oceanic plutonic rock, the primary rock-forming minerals are olivine, plagioclase, clinopyroxene, orthopyroxene, amphibole, FeTi oxides, sulfides, and rarely quartz. Four major classes of rock (peridotite, gabbro, dolerite, and basalt) are delineated on the basis of their igneous mineral assemblages and texture. Textures are defined on the basis of grain size, grain shape and habit, preferred mineral orientation, and mineral proportions.

For each primary silicate observed, the modal percentage within the lithology was visually estimated. In many cases, the estimation of primary modal mineralogy involved the observation of secondary mineralogy and inference from likely replacement reactions (e.g., replacement of plagioclase by chlorite). Visually estimated modal percentages likely reflect the primary igneous assemblages prior to alteration in most cases. Accessory phases such as additional oxide minerals, sulfide minerals, or others (e.g., zircon) were also noted where observed.

For each mineral where grain boundaries were distinguishable, the minimum, maximum, and modal grain size was recorded along with any observations of mineral shape and habit (see below). Grain size refers to the average long dimension of the minerals and is given in millimeters, as are the minimum and maximum crystal sizes. The following definitions and criteria were used.

- Dominant grain size:

- Very fine: $<0.2 \mathrm{~mm}$.

- Fine: $>0.2-1.0 \mathrm{~mm}$.

- Medium: >1.0-5.0 mm.

- Coarse: $>5-30 \mathrm{~mm}$.

- Mineral shape: euhedral, subhedral, and anhedral.

- Mineral habit:

- Equant: aspect ratio $<1: 2$.

- Subequant: aspect ratio 1:2 to 1:3.

- Tabular: aspect ratio $>1: 3$ to 1:5.

- Elongate: aspect ratio $>1: 5$.

- Lath-shaped: long and narrow, as for tabular-elongate.

- Granular: aggregate of interlocking roughly equant crystals.

\section{Oxide and sulfide minerals}

The abundance of primary Fe-Ti oxides and sulfides in the cores was visually estimated. Textures of oxide and sulfide minerals are described in terms of the habit of the mineral and its relationship with adjacent minerals. Relative sulfide abundance in hand specimen was visually estimated when possible. Oxide observed in hand specimens was divided into the following categories:

- Disseminated: scattered grain to grain clusters with no pronounced fabric.

- Interstitial network: oxides that occur interstitial to silicates.

In hand specimens, oxide minerals are also differentiated according to morphologies: euhedral, anhedral, angular aggregates, amoeboidal aggregates, and interstitial lenses. "Euhedral" and "anhedral" are used where isolated individual grains are present and oxide grain boundaries are observable. In plutonic rocks, oxides commonly occur as aggregates, and for grain size determination, an aggregate is counted as a single grain.

\section{Plutonic and mantle lithologies}

Igneous mafic and ultramafic rocks recovered during Expedition 357 are classified on the basis of abundance, grain size, and texture of their primary minerals based on the International Union of Geological Sciences (IUGS) system (Streckeisen, 1974; Le Maitre, 1989; Le Bas and Streckeisen, 1991) (Figure F13). Plutonic rock names were assigned on the basis of primary phases present prior to alteration. We have attempted to follow as closely as possible the descriptions from Ocean Drilling Program (ODP) Legs 153 and 209 and Integrated Ocean Drilling Program Expeditions 304/305, 309/312, 335, and 345 to allow comparison of these records. According to the definition of the Streckeisen (1974) diagram, gabbros are the most prevalent mafic plutonic rock in Expedition 357 cores and are defined as

$$
\begin{gathered}
\text { plagioclase }+ \text { clinopyroxene }>95 \% ; \\
\text { plagioclase }>10 \%, \text { clinopyroxene }>10 \% ; \\
\text { quartz }<5 \%
\end{gathered}
$$

Figure F13. Modal classification scheme for plutonic igneous rocks, Expedition 357 (after Streckeisen, 1974).

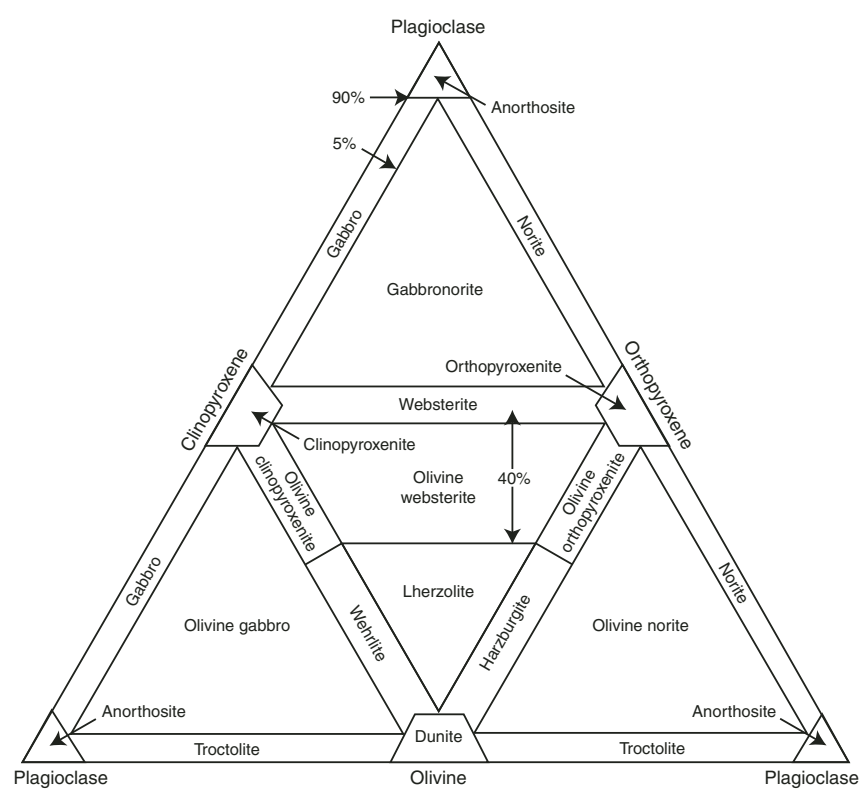


For ultramafic rocks, we define peridotite as containing olivine, spinel, and varying amounts of pyroxene, in which olivine makes up greater than $40 \mathrm{mod} \%$ of the rock. Accessory phases in the peridotites include spinel, plagioclase, ilmenite, chromite, and magnetite. The ultramafic protoliths of lithologies encountered during Expedition 357 are as follows:

- Dunite: olivine $>90 \%$ and spinel.

- Harzburgite: olivine $(40 \%-90 \%)+$ orthopyroxene $(5 \%-60 \%)+$ clinopyroxene $<5 \%$ and spinel.

- Porphyroclastic harzburgite: harzburgite with distinct, variably aligned porphyroclasts of relict orthopyroxene. Porphyroclasts are generally angular to lenticular in shape and show varying degrees of brittle deformation.

If a mafic rock exhibits the effects of dynamic metamorphism such that the assemblage consists of secondary minerals that completely obliterate the protolith mineralogy and texture or if the rock is made up of recrystallized primary minerals such that the original igneous protolith cannot be recognized, the appropriate metamorphic rock names such as "serpentinite" or "talc-amphibole-chlorite schist" are used. If primary assemblages and their pseudomorphs and textures can be recognized in ultramafic samples, even though they were partially or completely replaced, the rock name used is based on the reconstructed primary assemblage and IUGS classification and is termed either "serpentinized" or "altered" (e.g., serpentinized dunite, altered harzburgite, etc.). In some cases, serpentinization is accompanied by and/or overprinted by metasomatic talc-amphibole \pm chlorite alteration, which is described as metasomatically altered peridotite or metasomatically altered serpentinite. Where the modal abundance of secondary hydrous minerals exceeds $50 \%$ in mafic plutonic rocks, the prefix "meta-" was used with the igneous protolith name where possible (see Alteration and metamorphic petrology). If the rock exhibits the effects of dynamic metamorphism such that the assemblages consist of secondary hydrous minerals that completely obliterate the protolith texture or are made up of recrystallized primary minerals, the appropriate metamorphic rock names were used. The textural terms "mylonitic" and "schistose" (see Structural geology) where the textures are visible but not completely developed were added to metamorphic rock names such as "serpentinite" or "metagabbro" to indicate that the rocks exhibit the effects of dynamic metamorphism.

\section{Plutonic rock textures}

Igneous fabrics that were distinguished include "lamination" and "lineation" for rocks exhibiting a preferred orientation of mineral grains and "clusters" for mineral aggregates.

Some troctolite and lesser gabbro contain clinopyroxene oikocrysts. These oikocrysts are a macroscopic feature with a distinctive texture clearly observable in the cores. The oikocrysts have a welldefined spherical or augen-like habit that shows a clear boundary to the troctolitic or, less commonly, gabbroic matrix. Chadacrysts (enclosed grains) within the oikocrysts are clearly visible and are typically plagioclase. Olivine generally only occurs at the outermost rim. Because of their well-defined habit and clear relationships with other minerals, oikocrysts are easily identified with the naked eye. Poikilitic clinopyroxene grains are often very irregular in shape, forming large irregular clusters, with much less defined contact relations relative to the matrix. In more olivine rich gabbros, these clinopyroxenes also include olivine as chadacrysts, irrespective of whether they are located in the central part or rim of the clino- pyroxene. Macroscopic observations concerning oikocrysts are consistent with microscopic observations.

\section{Volcanic and hypabyssal rocks}

Basalts were described on the basis of grain size, phenocryst content (if any), and vesicles. If present, phenocrysts were used as modifiers in front of the rock name with a hyphen in between, according to their abundance. In the IUGS classification, "basalt" is defined on the basis of mineral mode or composition; grain sizes are variable. Dolerite is synonymous with diabase and refers to an intrusive basaltic rock emplaced as dikes or sills and characterized by subophitic to ophitic texture of plagioclase laths and augite, which could only be recognized in thin sections.

Where vesicles were observed in igneous rocks, their modal abundance (\%), size (minimum, maximum, and modal sizes in millimeters), roundness (rounded, subrounded, or well rounded), and presence of vesicle infilling were documented.

\section{Igneous textures}

We use the terms equigranular, inequigranular, and intergranular (only visible in thin sections) to describe the grain size distributions of igneous rocks. Inequigranular textures may be further described as seriate (continuous range of crystal sizes) or poikilitic (relatively large crystals of one mineral-oikocryst-enclosing smaller crystals of one or more other minerals-chadacrysts). Additional terms used are specific for the different habits of individual minerals, such as interstitial, poikilitic, acicular, lath-shaped, skeletal, and columnar (for more terms used, see Shelley, 1993). The most common igneous textures and volcanic rock terms employed are as follows:

- Igneous textures:

- Granular: aggregation of grains of approximately equal size.

- Ophitic: total inclusion of plagioclase in clinopyroxene.

- Subophitic: partial inclusion of plagioclase in clinopyroxene.

- Equigranular: all minerals are of one size.

- Inequigranular: two or more populations of grain size occur.

- Seriate: crystals of the principal minerals show a continuous range of sizes.

- Varitextured: domains with contrasting grain size are present.

- Porphyritic: phenocrysts ( $>1 \%)$ are surrounded by finer grained groundmass.

- Poikilitic: relatively large crystals of one mineral (oikocryst) enclose smaller crystals of one or more other minerals (chadacrysts).

- Volcanic rock terms:

- Aphyric: $<1 \%$ phenocrysts.

- Sparsely phyric: $1 \%-2 \%$ phenocrysts.

- Moderately phyric: $>2 \%-10 \%$ phenocrysts.

- Highly phyric: $>10 \%$ phenocrysts.

- Vesicularity:

- Vesicle poor: $<1 \%$ vesicles.

- Sparsely vesicular: $1 \%-5 \%$ vesicles.

- Moderately vesicular: $>5 \%-20 \%$ vesicles.

- Highly vesicular: $>20 \%$ vesicles.

- Groundmass crystallinity:

- Aphanitic: individual grains or phenocrysts cannot be distinguished.

- Microcrystalline: individual grains can be seen but not identified. 
- Fine grained: individual grains can be seen and identified $(<1$ $\mathrm{mm})$.

Volcanic rock and hypabyssal rock textures

The textural distinction between dolerite and microgabbro is based on the presence or absence of subophitic or ophitic textures. For basaltic rocks, the proportions and characters of phenocrysts, grain sizes, and vesicles define the textures. Phenocrysts are described for each mineral according to their abundance. The dominant grain size for all plutonic rocks was recorded as in the igneous textures list above.

Mineral modifiers such as "plagioclase-bearing" or "olivine-rich" were used to subdivide the rock types more accurately on the basis of significant mineralogical or textural differences rather than arbitrary cutoffs based on the abundance of a single mineral. For pervasively altered rocks, the term "primary mineralogy" or "primary assemblage" is used to refer to the estimated prealteration minerals or mineral assemblage.

Description of mafic igneous rocks follows that of ODP Leg 176 (Dick, Natland, Miller, et al., 1999) and Integrated Ocean Drilling Program Expeditions 304/305 and 345 (Expedition 304/305 Scientists, 2006; Gillis et al., 2014), where the following modifiers based on modal mineralogy were used:

- Lithology modifiers:

- Oxide: $>2 \%$ oxides, typically Fe-Ti oxide.

- Olivine: $>5 \%$ olivine.

- Troctolitic: $5 \%-15 \%$ clinopyroxene, $>20 \%$ olivine ( $>5 \%$ in gabbro).

- Anorthositic: $>80 \%$ plagioclase.

- Descriptive modifiers:

- Leucocratic: light colored; high proportions of plagioclase.

- Micro: rocks with a dominant grain size of $<1 \mathrm{~mm}$.

- Doleritic: fine- or medium-grained gabbroic rock with dominant ophitic or subophitic textures.

- Mineral modifiers:

- -bearing: $1 \%-5 \%$ of a mineral within a lithology.

- Disseminated: $1 \%-2 \%$ of a mineral dispersed throughout the lithology.

\section{Alteration and metamorphic petrology}

Metamorphic characteristics of Expedition 357 drill cores were determined using onshore VCDs, thin section descriptions by microscopy, and XRD analyses. The metamorphic petrology team worked in shifts and met daily to minimize measurement inconsistencies and agree on methodology and terminology. Alteration characteristics and metamorphic veins were described in handwritten VCDs, reported in Excel logs, entered into the ExpeditionDIS, and presented in compiled VCDs (see Core descriptions). For definitions of metamorphic terms used in the VCDs and logs, see Tables T2 and T3; criteria for describing veins followed the scheme shown in Figure F14. Compiled VCDs provide overview information on the intensity and nature of alteration types. These data are presented alongside consideration of primary mineral assemblages and structural observations.

In this volume, the terms "metamorphism," "alteration," and "hydration" are used loosely and interchangeably without making implications about open- versus closed-system behavior. The terms "serpentinization," "rodingitization," "talc-amphibole-chlorite metasomatism," and "oxidation" are used to describe the predominant alteration types and imply a chemical change in the composition of the primary ultramafic or mafic rocks. Because we were not able to
Table T2. Mineral acronyms used during Expedition 357. Download table in .csv format.

\begin{tabular}{ll}
\hline Acronym & \multicolumn{1}{c}{ Mineral } \\
\hline Act & Actinolite \\
Alb & Albite \\
Amph & Amphibole \\
Ant & Antigorite \\
Arag & Aragonite \\
Brc & Brucite \\
C-chry & Clino-chrysotile \\
Carb & Carbonates \\
Cc & Calcite \\
Chl & Chlorite \\
Chry & Chrysotile \\
Cly & Clay minerals \\
Cpx & Clinopyroxene \\
Crm & Chromite \\
CrSp & Cr spinel \\
Dio & Diopside \\
Dol & Dolomite \\
Ep & Epidote \\
Gre & Greenalite \\
H-ox & Hydroxide \\
Liz & Lizardite \\
Mag & Maghemite \\
Mt & Magnetite \\
Ol & Olivine \\
Opx & Orthopyroxene \\
Ox & Oxide \\
Plag & Plagioclase \\
Preh & Prehnite \\
Qtz & Quartz \\
Smec & Smectite \\
Sp & Spinel \\
Srp & Serpentine (group) \\
Sulf & Sulfide \\
Tit & Titanite (sphene) \\
Tr & Talc \\
\hline & Tremolite \\
Zeo & Zoisite \\
\hline
\end{tabular}

macroscopically evaluate changes in bulk composition, we considered the alteration reactions as primarily corresponding to the addition of $\mathrm{H}_{2} \mathrm{O}$ and calcium, the gain or loss of silica, and the oxidation of ferrous to ferric iron.

\section{Alteration textures}

Alteration textures and their relationships to the primary phases in the mafic and ultramafic rocks are generally related to the hydration of olivine, pyroxene, and plagioclase, where present. During Expedition 357, intervals with the following textures related to serpentinization, metasomatism, and oxidation were documented:

- Serpentinization textures: hydration textures after olivine and pyroxene; serpentine recrystallization textures and serpentine veins.

- Metasomatic textures: rodingitization and talc-amphibolechlorite metasomatism.

- Oxidation textures: typically indicated by a change in color to more red/orange, which either occurs pervasively or locally. The color change is considered to be primarily related to iron oxidation.

A description of the alteration of strongly fractured rock fragments and clasts within cataclastite are described in the comments field of the ExpeditionDIS. 
Table T3. Glossary of metamorphic petrology terms used during Expedition 357. Download table in .csv format.

\begin{tabular}{|c|c|}
\hline Term & Definition \\
\hline Alteration patch & $\begin{array}{l}\text { Polycrystalline domain, more or less isolated and surrounded by host rock, that is compositionally distinct from the host rock. Patches can be secondary } \\
\text { features (i.e., as a consequence of patchy alteration) or primary igneous features where differences may have been enhanced by alteration. }\end{array}$ \\
\hline Apparent fibers & Cross sections of serpentine plates that look fibrous in thin section. \\
\hline Asbestiform & Crystals (chrysotile or tremolite) are thin hairlike fibers that are mechanically separable. \\
\hline Background alteration & Alteration has pervasively affected the entire rock and is not primarily bound to veins or foliation planes. \\
\hline Banded vein & Vein with rhythmic layering parallel to the vein walls. \\
\hline Bastite & $\begin{array}{l}\text { Serpentine texture after chain and layer silicates preserving important features of the protolith (e.g., plastic deformation) and preserpentine alteration } \\
\text { assemblages. }\end{array}$ \\
\hline Brucite & $\begin{array}{l}\text { Tentatively identified by anomalous cream-brown interference colors, by yellow color in plane-polarized light (if weathered), and by shape (more } \\
\text { bladed or prismatic than serpentine). }\end{array}$ \\
\hline Chrysotile & White asbestiform serpentine, most easily identifiable in cross-fiber veins. \\
\hline Composite vein & Compositionally and structurally zoned vein containing different mineral assemblages that may or may not represent different generations. \\
\hline Cross-fiber vein & Asbestiform or pseudofibrous vein in which the fibers (or apparent fibers) are oriented perpendicular to the vein walls. \\
\hline Fibrous & $\begin{array}{l}\text { Single crystals resembling organic fibers or crystalline aggregates that look like they are composed of fibers. If fibers are mechanically separable (e.g., by } \\
\text { probing the sample with a needle), they are asbestiform. If they are not separable, they are pseudofibrous. If fibers have the normal strength and } \\
\text { brittleness of the mineral, they are acicular. }\end{array}$ \\
\hline Hourglass texture & $\begin{array}{l}\text { Similar to mesh texture, but a distinction between mesh rim and mesh center is not possible. This texture is related to fractures in the mineral grains of } \\
\text { the protolith and hence is not strictly a pseudomorphic texture. }\end{array}$ \\
\hline Interlocking texture & Texture with more or less equant serpentine grains, possibly of various size. Often develops after a preexisting serpentine texture. \\
\hline Interpenetrating texture & Elongated and blade-like serpentine grains. Orientation varies from random to preferential. Often develops after a preexisting serpentine texture. \\
\hline Massive vein & Veins that are homogeneous and completely filled. \\
\hline Mesh textured serpentine & $\begin{array}{l}\text { Replacement texture resembling a fisherman's net. The mesh rim represents the cord of the net, and the mesh centers represent the empty areas } \\
\text { between the cords of the net. The outer edge of a mesh cell coincides either with a grain boundary or with a fracture within the primary mineral. This } \\
\text { texture is related to fractures in the mineral grains of the protolith and hence is not strictly a pseudomorphic texture. }\end{array}$ \\
\hline Non-pseudomorphic texture & $\begin{array}{l}\text { Does not preserve the texture of the protolith. Can only be recognized under cross-polarized light. Includes interpenetrating and interlocking textures. } \\
\text { Includes mesh, interpenetrative, and interlocking textures. }\end{array}$ \\
\hline Paragranular vein & Anastomosing vein or vein network that is foliation parallel and wraps around porphyroclasts. \\
\hline Picrolite & $\begin{array}{l}\text { Vein-filling serpentine that is white, cream, pale yellow, to apple green and may be either massive or pseudofibrous in habit. Picrolite can be either } \\
\text { lizardite, chrysotile, or antigorite. Picrolite veins are usually transgranular. }\end{array}$ \\
\hline Pseudofibrous & Crystals or crystalline aggregates that have a fibrous appearance but are not composed of separable fibers. \\
\hline Pseudomorphic texture & Metamorphic texture that preserves the primary texture of the protolith (e.g., bastites). Can be recognized in plane-polarized light. \\
\hline Ribbon texture & $\begin{array}{l}\text { Special form of transitional texture in which the mesh texture presents an apparent preferential orientation. Mesh rims oriented along this direction are } \\
\text { the most developed and look continuous form one mesh cell to the other. }\end{array}$ \\
\hline Rodingite & $\begin{array}{l}\text { A metasomatized rock enriched in } \mathrm{Ca} \text { and/or depleted in } \mathrm{Si} \text { in which the primary igneous composition and texture have been destroyed to an extent } \\
\text { that the nature of the protolith may be uncertain. Typically found grading to chlorite rich zones or "blackwalls." If the nature of the protolith can be } \\
\text { discerned but marked rodingite-style alteration is obvious, the rock was described as rodingitized. }\end{array}$ \\
\hline Selvages & Wallrock along a vein that is completely altered to secondary minerals and has a sharp contact to the host rock. \\
\hline Slip-fiber vein & Asbestiform or pseudofibrous vein in which the fibers (or apparent fibers) are oriented more or less parallel to the vein walls. \\
\hline Transgranular vein & Vein or vein network at any angle to the foliation planes that crosscut porphyroclasts and/or other large crystals. \\
\hline Vein halos & $\begin{array}{l}\text { Zones (millimeter to centimeter wide) along a vein in which the rock is more intensely altered or altered in a different style than the host rock. A halo can } \\
\text { have a sharp or diffuse contact to the host rock. }\end{array}$ \\
\hline Vuggy vein & Incompletely filled vein. \\
\hline
\end{tabular}

\section{Serpentine alteration textures}

Ultramafic rocks recovered during Expedition 357 were interpreted to be mantle rocks that experienced (1) high-temperature, dynamic metamorphic recrystallization during upwelling and melting in the mantle, in some instances creating macroscopically identifiable protogranular or porphyroclastic textures, followed by (2) a stage of lower temperature static replacement and/or dynamic recrystallization during emplacement and alteration near the seafloor under lower temperature, hydrous conditions (see Structural geology). Altered ultramafic rocks show varying degrees of alteration, drilling-induced fracturing, and crystal-plastic deformation. Alteration is dominated by serpentinization reactions and serpentinebearing mineral assemblages that progressively replace primary olivine and orthopyroxene. The main alteration products of olivine are typically serpentine, magnetite, and brucite; however, brucite has not been identified through microscopic observation or by XRD analyses of core samples. In altered oceanic peridotites, serpentine can be found as five different types with different crystallographic properties: lizardite, chrysotile, and more rarely antigorite, as well as polygonal and polyhedral serpentines. Lizardite and chrysotile are the most common serpentine phases at mid-ocean ridges. Anti- gorite is not strictly a polymorph because of its slightly higher $\mathrm{Si} / \mathrm{Mg}$ ratio compared to stoichiometric serpentine. Where hydrous alteration in ultramafic rocks was so extensive that estimation of the primary phase assemblages was not possible, the rock was called "serpentinite." In cases where primary assemblages and textures could still be recognized, the adjective "serpentinized" was added before the protolith name (e.g., serpentinized dunite and serpentinized harzburgite).

Textures of serpentines include three types: (1) textures after olivine and pyroxene hydration, (2) recrystallization textures, and (3) veins. We adopted the following definitions for the most common serpentine occurrences in the altered peridotites recovered at Atlantis Massif:

- Mesh texture: serpentine texture after olivine that resembles a fisherman's net. It can be identified at the macroscopic scale but is more easily identified at the microscopic scale. This texture develops along olivine grain boundaries and intragranular microfractures that define the mesh cells. Mesh cells are composed of mesh rims, generally of pseudocolumnar lizardite growing orthogonally to the hydration front and toward the mesh center, and mesh cores, made of olivine relics or isotropic serpentine. A 
Figure F14. Vein classifications used in the vein log, Expedition 357.

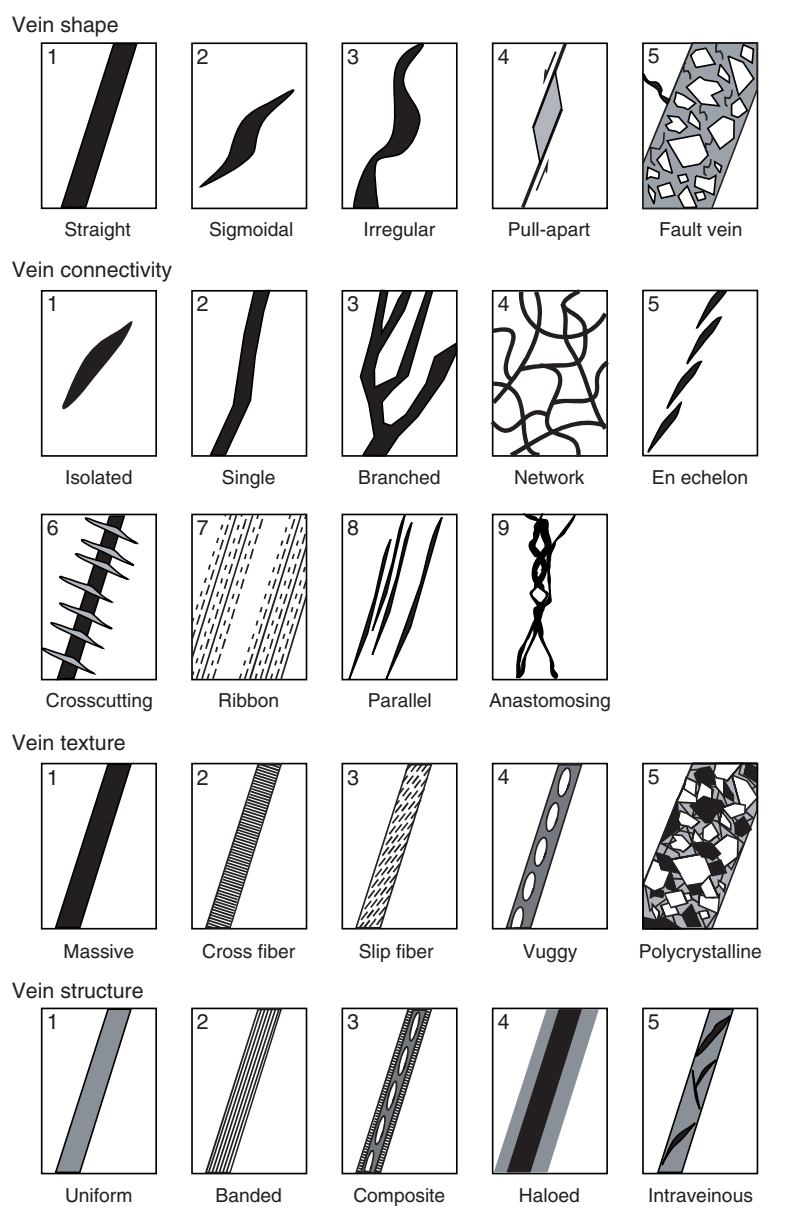

mesh texture contains mesh cells with rims of similar width. In contrast, cells of ribbon textures have rims of different widths resulting from spatially heterogeneous serpentinization, highlighting a hydration-preferential orientation. In the hourglass texture, mesh rims reach the cell center and mesh cores do not exist.

- Bastite: serpentine texture after pyroxene (generally orthopyroxene). Serpentinization progresses from the pyroxene grain boundaries, cleavage planes, and intragranular microfractures toward the center of the grain, often resulting in a pseudomorphic texture that mimics the primary pyroxene shape and preserves important features of the protolith (e.g., cleavages and plastic deformation).

- Interlocking texture: microscopically, this texture is composed of equant to spherulitic serpentine grains. It develops by recrystallization of a mesh texture or occasionally a bastite texture.

- Interpenetrative texture: microscopically, this texture is composed of elongated serpentine grains that form blades. The orientation of these blades varies from random to preferential. It develops by recrystallization of a mesh texture or occasionally a bastite texture.

- Fibrous veins: typically lens-shaped veins in which continuous chrysotile fibers link the two walls of the vein. The fibers are sometimes visible at the macroscopic scale.

- Banded veins: typically continuous veins presenting an infill made of thin bands parallel to the vein walls. At the macroscopic scale, the infill looks homogeneous.
- Lamellar, granular isotropic veins: veins generally showing irregular, nonmatching walls and homogeneous infill. At the microscopic scale they are filled with serpentine lamellae growing from each wall of the vein toward its center, triangular-shaped serpentine sectors producing black cross-extinction under cross-polarized light, and an isotropic serpentine.

Magnetite is commonly present in all of these textures, observed as tiny grains that concentrate along microfractures in the mesh or in serpentine veins. It forms after olivine hydration and incorporates part of its iron under reduced and oxidized forms. Further definitions are provided in the glossary (Table T3). Observations and measurements of serpentine fabrics are discussed further in Structural geology and are summarized in Figure F15.

\section{Metasomatic alteration}

Talc-amphibole-chlorite alteration

The ultramafic and gabbroic rocks recovered during Expedition 357 show varying degrees of metasomatic alteration to talc-rich, amphibole-rich, and/or chlorite-rich assemblages. They appear as distinctly light green to white rocks with a soapy feel and are usually very fractured and variably sheared (even if static replacement is also observed). They locally show pervasive overprinting of the precursor mineral assemblage with varying proportions of talc, amphibole, and chlorite ( \pm serpentine). At a microscopic scale, metasomatic zones are characterized by very fine grained talc-amphibole-chlorite intergrowths. Based on Boschi et al. (2006), the abundance of the three minerals is strictly linked to the protolith. A gabbroic protolith tends to be more chlorite and amphibole rich (with minor talc and no serpentine), whereas an ultramafic protolith is talc dominated, with variable proportions of amphibole and chlorite.

The talc-rich rocks with an ultramafic protolith occasionally preserve the original porphyroclastic texture with precursor ribbon or mesh serpentine, in which case these rocks could also be referred to as talc-amphibole serpentinites. Serpentine is present in relict domains, but it is also observed as newly formed crystals intergrown with talc or as localized pockets of recrystallized antigorite with nonpseudomorphic interlocking texture. Talc occurs as a replacement product of groundmass serpentine and may occur together with tremolite \pm chlorite as alteration products of bastite pseudomorphs after orthopyroxene.

Strongly foliated talc-amphibole-chlorite schists are the most distinctive fault rocks at Atlantis Massif. They typically show a heterogeneous mylonitic texture characterized by strong foliation defined by shape-preferred orientations, which is locally overprinted by a crenulation lineation. The mylonitic planar foliation is composed of alternating layers of variably sized synkinematic talc, Caamphibole, and chlorite. Occasionally, lenses are embedded that have a sigmoidal texture and represent strongly deformed orthopyroxene porphyroclasts. Pyroxene ribbons are commonly altered to patches of talc + amphibole \pm chlorite and show strong undulose extinction, subgrain structures, and dynamic recrystallization, mainly along the rim of the ribbons. Kinematic indicators in the talc-amphibole-chlorite schists include asymmetrical foliation patterns, pressure shadows around pyroxene porphyroclasts, and local folds. These indicators indicate normal slip top-to-east (toward the spreading axis) or southeast (toward the transform). Crenulation lineation is defined by amphibole neoblasts that formed at a high angle to the foliation, suggesting that amphibole continued to grow after the formation of the mylonitic foliation. 
Figure F15. Intensity and intensity ranks for magmatic, crystal-plastic, schistosity, cataclastic/semibrittle deformation fabrics, veins, and brittle cracks/open fractures, Expedition 357.

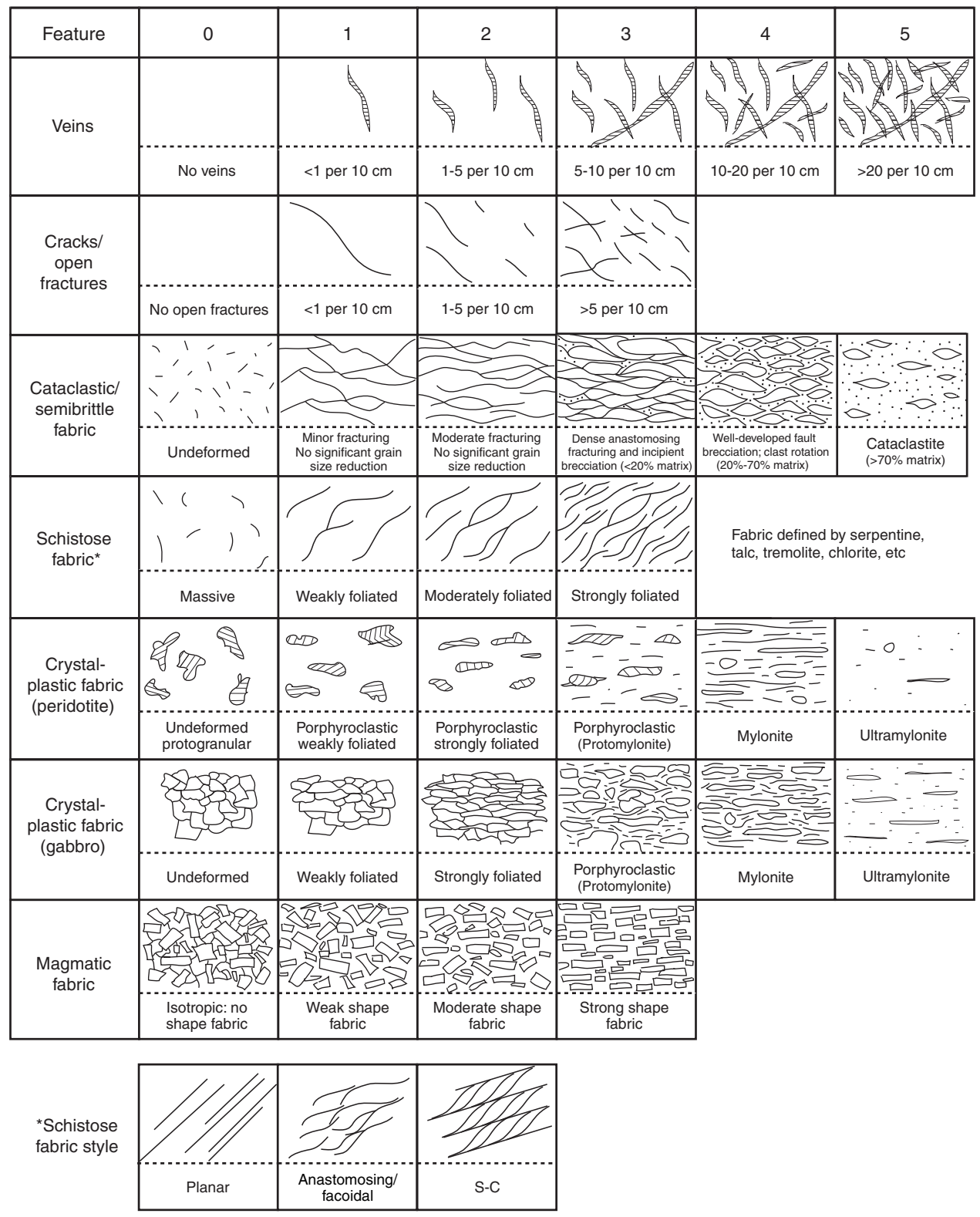

In contrast to the talc-rich rocks, alteration to amphibole-rich assemblages commonly obliterates the primary textures and precursor mineral paragenesis, preventing an unequivocal petrographic determination of the protoliths. Moreover, amphibole-rich rocks have alteration textures that are distinct from those of talcrich rocks. Amphibole-rich rocks consist of well-crystallized, elongate, and often aligned amphibole that wraps around lenses and patches of amphibole \pm chlorite that resemble porphyroclasts. Some of these lenses are conceivably pseudomorphs after pyroxene porphyroclasts. Porphyroclasts are generally deformed and elongated, commonly bent, and display patchy, undulose extinction. Acicular grains of amphibole locally define pressure shadows around the crystals and define the foliation. Talc is typically absent in these rocks, or it occurs only locally with fine-grained needles of amphibole and chlorite as pseudomorphs of orthopyroxene porphyroclasts. Amphibole-rich rocks generally show geochemical characteristics that outline either a mafic or an ultramafic protolith veined by mafic intrusion.

\section{Rodingitization}

The term rodingite is used for metasomatized mafic rocks associated with serpentinites and chlorite-rich zones (blackwall alteration) that are characterized by incipient "Ca-metasomatism" or by an increase in the $\mathrm{Ca} / \mathrm{Si}$ ratio. Macroscopically, rodingites appear as a dense white and pink to pinkish brown rock surrounding smaller, darker remnants of coarse-grained protolith. In thin section, the darker domains consist of green actinolitic amphibole that typically replaces primary clinopyroxene. Amphibole typically coexists with both coarse- and fine-grained prehnite (comprising white zones in hand samples) associated with very fine grained aggregates of prismatic clinozoisite with minor titanite and chlorite (concentrated in pink zones). Prehnite forms faintly yellowish white lamellar to platy 
aggregates, and some of the plates occur as fan-shaped arrays. Finegrained aggregates of clinozoisite appear as cloudy darker areas, and small pockets of bluish chlorite can occur together with titanite.

\section{Oxidation}

Here we use the term oxidation to imply that the $\mathrm{Fe}^{2+}$ in Fe-bearing minerals in ultramafic or mafic rock has been partly to completely oxidized to $\mathrm{Fe}^{3+}$, which is reflected by a change in color to red or orange due to low-temperature aqueous alteration (weathering) of the basement rocks that is well known along slow-spreading ridges. This alteration produces minor to dramatic textural and compositional modifications, depending on the age of the rock. Fe oxyhydroxides, clay minerals, and calcium carbonate fill multiple generations of brittle fractures. Oxidation, including formation of goethite and/or hematite, is one of the first steps of the weathering process. Oxidation of serpentinites usually affects veins, mesh texture, and bastites. Strong weathering of mafic or ultramafic rocks typically includes precipitation of secondary low-temperature (phyllo)silicate minerals such as palygorskite, smectite, saponite, nontronite, and Fe-rich montmorillonite.

\section{Alteration handwritten VCDs and logs}

The onshore handwritten VCD forms and alteration logs (see COREDESC in Supplementary material) provide information on (1) the predominant type of alteration and the intensity and extent of replacement of primary minerals by secondary minerals and (2) the nature and approximate modes of secondary mineral assemblages. They also record overprinting alteration relationships and any association between alteration and deformation fabrics. Except for simple cases, estimates of individual modes of alteration minerals were only possible where thin sections or XRD data were available. Where several intervals or pieces showed similar characteristics, secondary mineral modes were assigned to the whole group on the basis of thin section or XRD analysis.

Some of the observations made on the VCDs were reported on the alteration $\log$ (see COREDESC in Supplementary material), which describes alteration assemblages and textures on an interval basis. The intervals in the alteration log do not necessarily correspond to the lithologic intervals defined by the igneous petrology team. Alteration assemblages were described by color and estimated mineralogy and refined by thin section and XRD study. A distinction was made between overprinting alteration assemblages and assemblages localized by preexisting lithologic changes. For example, a core of serpentinized dunite containing a gabbro dike altered to a talc-amphibole-chlorite assemblage is described as three discrete intervals on three rows in the log. On the other hand, a core of serpentinized dunite containing an interval with vein halos is described using two rows: one long interval of serpentinized dunite and a shorter interval containing the overprinting vein halo assemblage. In the latter case, textures are assigned a percentage corresponding to the surface they occupy in the sample and the vein data are logged separately unless the vein had an extensive halo.

The alteration log summarizes the site, hole, core, section, and depth range of the core interval considered, as well as quantification of the texture extent and intensity of the identified alteration minerals. The types of textures include the following:

- Serpentinization,

- Rodingitization,

- Talc-amphibole-chlorite metasomatism,

- Oxidation,
- A category grouping other occasional textures primarily observed in the mafic rocks, and

- A category indicating mixed alteration types, when the relative abundances could not be determined (e.g., rubble intervals with varying types of altered clasts).

When present, any alteration texture was associated with a percentage representing its proportion on the core cut face (such that the sum of all alteration texture areal proportions is 100\%). Typically, several of these alterations were identified within the same lithologic intervals because alteration style and intensity commonly vary with primary igneous mode.

Intensity of alteration was recorded for each texture. It represents an estimate of the proportion of primary minerals replaced by secondary minerals (i.e., the reaction advancement). This estimate was refined when thin section and XRD data observations were available. The scale used for documenting the intensity was as follows:

- Fresh: $<2 \%$.

- Slight alteration: $2 \%-20 \%$.

- Moderate alteration: $21 \%-40 \%$.

- High alteration: $41 \%-80 \%$.

- Very high alteration: $81 \%-95 \%$.

- Total alteration: $>96 \%$.

Characterization of alteration textures was completed by an indication of their geometry and distribution throughout the interval:

- Pervasive: alteration affecting the entire background.

- Localized: alteration occurring along specific features of the host rock, such as fractures and rims.

- Patches: polycrystalline domain, more or less isolated from the rock background, whose alteration is distinct from the host rock.

Finally, secondary minerals that were clearly identifiable were listed (serpentine, talc, amphibole, chlorite, magnetite, carbonates, oxides, and sulfides).

\section{Veins and alteration halos}

During Expedition 357, a combined vein log was recorded in conjunction with the structural geology team (see COREDESC in Supplementary material). Veins and vein sets were recorded on an interval basis, and vein-free intervals were also noted. Where several vein types were present in an interval, they were recorded on separate rows. In the metamorphic/alteration part of the vein log, we recorded vein color and secondary minerals present. Vein textures were classified using a series of codes (Figure F14) and recorded in the following terms:

- Shape: straight, sigmoidal, irregular, pull-apart, and fault vein.

- Connectivity: isolated, single, branched, network, en echelon, crosscutting, ribbon, parallel, and anastomosing.

- Texture: massive, cross-fiber, slip-fiber, vuggy, and polycrystalline.

- Structure: uniform, banded, composite, haloed, and intravenous.

Any vein that did not fit into the classification scheme was entered as a separate code and described in a comment. The color and width of alteration halos that bind veins were recorded, along with comments on general appearance. Acronyms used in the alteration 
and vein logs and thin section description forms are listed in Table T2.

\section{Structural geology}

Structural observations and measurements carried out during Expedition 357 generally followed the conventions adopted during Integrated Ocean Drilling Program Expeditions 304/305 and 345, which in turn were based on previous hard rock drilling programs (e.g., ODP Legs 118, 131, 140, 147, 153, 176, 179, and 209). Where procedures followed directly from previous expeditions, references to the appropriate Explanatory notes and Methods chapters are given.

\section{Overview of macroscopic structural descriptions}

Whole cores were oriented for cutting by the structural geology team at the OSP. Cores were marked to maximize dip on planar structures so that the dominant structure dips toward $270^{\circ}$ in the core reference frame (i.e., toward the right looking down at the cut surface of the archive half) and equal proportions of any feature (rock type, deformation fabrics, veins, etc.) are preserved in both the working and archive halves. Where no obvious structures were present, cores were marked to maximize contiguity with adjacent core intervals or core pieces. The sign convention for the core follows the paleomagnetic conventions of a right-hand rule with $+z$ as vertical and downcore (Figure F16).

All descriptions and structural measurements were carried out on the archive halves. Structural data were entered into a VCD form used in conjunction with various spreadsheet logs to obtain downhole tectonic measurements (see COREDESC in Supplementary material). Hand-drawn structural sketches made on VCDs were used to illustrate the most representative structures and crosscutting relationships in a core section and were scanned as PDF files; in addition, a brief general description of the structures was entered into the ExpeditionDIS and printed on the final versions of the VCDs (see Core descriptions). Five additional spreadsheets were used for recording specific structures and measurements during core description. Description and orientation of all structural features followed the criteria summarized in Figure F15. Data were recorded using curated depth so that "structural intervals" could be correlated with lithologic core descriptions and included the following:

Figure F16. Core reference frame (CRF) used for orientation of planar structures and apparent dips on cut surfaces, Expedition 357. Orientations are given as three-digit numbers $\left(0^{\circ}-360^{\circ}\right)$ and dip angles as two-digit numbers $\left(0^{\circ}-90^{\circ}\right)$.

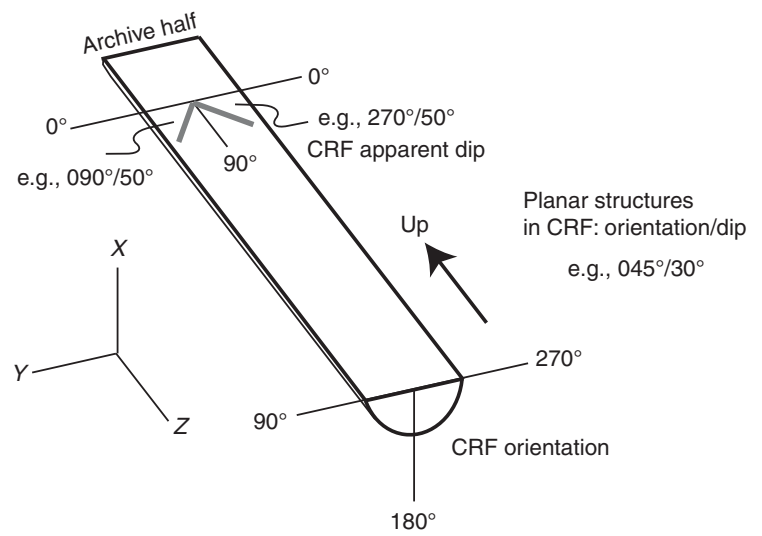

- Orientation and type of metamorphic veins and open fractures.

- Brittle and semibrittle structures: fractures, gouge, breccia, and cataclasite, including cataclastic/semibrittle fabric intensity.

- Schistose structures and style (in talc-, amphibole-, chlorite-, and/or serpentine-bearing intervals): undeformed to strongly oriented, planar, anastomosing, and/or S-C.

- Crystal-plastic deformation (primarily in gabbro and peridotite): mylonitic foliation and sense of shear.

- Igneous structures: magmatic foliation, compositional layering, shape-preferred orientation of minerals or mineral alignment, and any igneous contacts and their characteristics (e.g., gradational, magmatic vein, and intrusive).

\section{Structural measurements}

Structural features were recorded in centimeters from the top of each core section. Depth was defined as the point where the structure intersects the right-hand $\left(270^{\circ}\right)$ side of the cut face of the archive half (Figure F16) or, if the feature does not appear, the depth of the centroid of the feature projected to the right-hand side of the core. Where they occur, crosscutting relationships were described with core section depth. Apparent microfault displacements of planar markers were recorded as they appeared on the cut face of the archive half of the core. Shear sense indicators (asymmetric shear bands, asymmetric pressure shadows around porphyroclasts, bending of fabrics toward zones of high strain, imbrication of elongation of clasts in cataclasite, etc.) were also noted on the spreadsheets. Slickenside and/or slickenfiber orientation trend and plunge measurements or the trend and plunge direction of the slip line between offset linear markers were incorporated when possible to determine dip-slip, oblique-slip, or strike-slip components. Observations of lineations (slickenside and/or slickenfiber) were limited because of the highly fracture nature of the core.

\section{Fabric intensities}

A semiquantitative scale of deformation and alteration fabric intensities was used during core description. These scales, shown in Figure F15, were modified from the deformation scales used during ODP Legs 176 (Shipboard Scientific Party, 1999) and 209 (Shipboard Scientific Party, 2004). Where possible, we assigned specific values to intensity estimates (e.g., vein spacing or matrix percentage in a cataclastic zone). For some categories, however, classification was difficult (e.g., the intensity of any crystal-plastic fabric), in which case we used the previously adopted qualitative estimates of intensity based on hand-specimen and thin section observations. We documented distinct types of fabric intensity measurements:

- Magmatic: presence and intensity of any shape-preferred orientation of magmatic phases. Four levels, from no shape-preferred orientation (0) to strong shape-preferred orientation (3), were used.

- Crystal-plastic: six levels of deformation intensity were used (for gabbroic rocks), ranging from a lack of any crystal-plastic fabric (0) through three stages of foliation and porphyroclast development (1-3) to mylonitic and ultramylonitic fabrics (4-5). The textural criterion used for gabbroic rocks, on which this was based, was modified slightly for peridotite to also include six levels of deformation intensity ranging from undeformed protogranular (0) through three stages of porphyroclast development (1-3) to mylonite and ultramylonite (4 and 5). Occasionally, it proved difficult to differentiate between crystal-plastic and cataclastic/semibrittle deformation in relatively high strain shear zones based on hand-specimen observations only. In this case, 
we listed the structures in both spreadsheets and described the structures in detail in the VCDs.

- Schistosity intensity and style: four levels of schistose fabric were used based on the intensity of fabric development, ranging from random (0) to weakly, moderately, or strongly oriented (13). Styles of schistosity include planar, anastomosing, S-C/shear bands, or mixed.

- Cataclastic/semibrittle: six levels of deformation intensity were used with fabrics depending on the percentage of matrix present within each cataclastic zone. Thin section descriptions, wherever available, significantly aided this categorization.

- Brittle/open fractures and cracks (fractures without displacement): four levels of joint density were used, depending on the average frequency of open fractures and/or cracks across a 10 $\mathrm{cm}$ depth interval along the right-hand $\left(270^{\circ}\right)$ side of the core. Fractures were distinguished from faults (cataclastic features) by the lack of any identifiable offset. Some sections of the core contained small subhorizontal microfractures commonly related to unloading accompanying drilling. The same scale as for fractures $(0-3)$ was used for the density of these drilling-induced features.

- Veins: six levels of vein density were used, depending on the average frequency of veins across a $10 \mathrm{~cm}$ depth interval along the long axis of the core. Alteration veins are those that contain metamorphic phases. In some cases, these veins may have originally been igneous, but no primary phases or their characteristic pseudomorphs were recognized. Magmatic veins are compositionally distinct mineral segregations that may be concordant or discordant.

For each of the structural logs (alteration, vein, brittle deformation, plastic deformation, and magmatic structure), one or more successive depth intervals within each core were defined with a common structural characteristic, and, when possible or relevant, a representative structural measurement (orientation and dip) of individual structures or a set of structures (e.g., faults, veins, cracks, foliation, and schistosity) was recorded. Structural units in the different logs for a given core can be different based on core characteristics.

\section{Fabrics in serpentinized peridotites}

Abyssal peridotites represent a special problem for grading crystal-plastic deformation because they have commonly been emplaced from the mantle by high-temperature crystal-plastic creep processes and therefore lack a primary igneous texture. They generally have either protogranular or porphyroclastic textures when unmodified by relatively shallow deformation processes associated with unroofing and exposure to the seafloor. Protogranular textures are generally the earliest fabric and are characterized by smoothly curved grain boundaries with complex cusps and lobes (Figure F15). However, alteration has generally entirely obscured olivine grain size and shape in hand specimens in abyssal peridotites, and visual core description is almost entirely based on pyroxene and spinel textures. Crystal-plastic deformation grades, therefore, are as follows:

- 0: purely protogranular texture; this is the earliest formed texture and may or may not have a preferred crystallographic mineral fabric or a shape fabric. Porphyroclastic textures are generally superimposed on protogranular textures, and frequently elements of both are present. In this case, we used the name of the predominant texture; the intensity grade 0.5 indicates that elements of both textures are prominent.
- 1: (porphyroclastic) texture defined by relict orthopyroxene if there is only a weak or no pyroxene shape fabric developed.

- 2: (porphyroclastic) pyroxene exhibits a significant shape fabric, noting that only a few protogranular textural elements are present; these intervals are still referred to as porphyroclastic.

- 3: (protomylonite) the shape fabric is strong with well-developed foliation accompanied by significant grain size reduction (protogranular abyssal peridotites generally have a pyroxene grain size of around 3-6 mm). At this grade, there are generally no relict protogranular textural elements.

- 4: (mylonite) peridotite has significant grain size reduction and consists of a fine-grained mass of olivine with embedded pyroxene porphyroclasts and prominent foliation.

- 5: (ultramylonite) no foliation is visible because of extreme grain-size reduction.

This deformation scale closely parallels that used for gabbro here and during previous legs/expeditions and represents very similar or the same intensities of deformation at each grade.

\section{Thin section descriptions}

Thin sections were described by members of the core description teams and entered into an Excel template. Observations made on thin sections were used to inform core descriptions and integrated into the igneous, metamorphic, and structural sections for each site. Most samples were altered, and estimates of primary mineral modes were made based on alteration assemblages and textures where possible, but these estimates should be considered approximate and preliminary. Estimates were made of modes of alteration minerals based on visual observation, but many samples are very heterogeneous, so these are also approximate. Structural observations were entered in a comments section, and a list of photomicrographs with brief comments was added. Thin section description spreadsheets were signed by the principal observer. Thin section spreadsheets are available in Core descriptions, and microphotographs made during description are available in COREDESC in Supplementary material.

\section{X-ray diffraction}

\section{Sample preparation}

Dried bulk rock samples (see Geochemistry) were reduced in size with a stainless steel impact mortar and pestle (Chemplex). Rock chips were then ground by hand to a fine powder $(<20 \mu \mathrm{m}$ particle size to prevent particle size effects) using an agate mortar and pestle and/or a Planetary Micro Mill "Pulverisette 7" (Fritsch) as indicated in Geochemistry. Dry samples were milled with agate grinding bowls and balls at a rotation speed of $600 \mathrm{rpm}$ for $2 \mathrm{~min}$ followed by a $1 \mathrm{~min}$ pause to allow the material to cool. This process was repeated three times. To clean the device between samples, a teaspoon of quartz (fine granular, washed, and calcined for analysis; Merck) was milled and then the grinding bowls and balls were washed twice with pure ethanol.

\section{Instrument parameters}

XRD pattern analyses were conducted in the Crystallography research group laboratories (Department of Geosciences, University of Bremen [Germany]). Powders were prepared and measured with the Philips backloading system to prevent preferential orientation of grains. Analyses were conducted on a high-end Philips $\mathrm{X}$ 'Pert Pro multipurpose diffractometer equipped with a $\mathrm{Cu}$-tube (K入 1.541, $45 \mathrm{kV}, 40 \mathrm{~mA}$ ), a fixed divergence slit of $0.25^{\circ}$, a 15 sample changer, a secondary monochromator, and the $\mathrm{X}$ 'Celerator detector 
system. Measurements were done by continuous scanning from $3^{\circ}$ to $85^{\circ} 2 \theta$ with a calculated step size of $0.016^{\circ} 2 \theta$. The calculated time per step was $50 \mathrm{~s}$. A standard deviation of $\pm 5 \%$ is the general reproducibility of the measurement for mineral groups with $>20 \%$ clay fraction (Moore and Reynolds, 1989). For well-crystallized minerals including olivine, pyroxene, and the carbonate series, standard deviations are smaller (Tucker, 1988).

\section{Mineral identification and semiquantification}

The Philips software X'Pert HighScore was used for mineral identification and semiquantitative evaluation of mineral abundance. Semiquantification was determined on the basis of relative intensity ratio values. These values were calculated as the ratio of the intensity of the most intense reflex of a specific mineral phase to the intensity of the most intense reflex of pure corundum $\left(I / I_{\mathrm{c}}\right)$, referring to the matrix-flushing method of Chung (1974). Total percentages calculated by the software sometimes slightly exceeded $100 \%$. Sum totals less than $100 \%$ are likely due to the presence of amorphous or poorly crystallized material.

\section{Geochemistry}

\section{Onshore bulk rock inorganic chemistry analyses \\ Bulk geochemical analysis of whole rocks}

During the offshore phase, 10 rock samples were collected for bulk measurements of solid phase major and trace elements. Additional samples were collected during the onshore phase. During previous OSP operations, powders for bulk rock geochemical analysis were prepared in Bremen using a stainless steel bowl, pressure mortar, and Pulverisette 7 planetary mill with either agate or stainless steel jars and $1 \mathrm{~cm}$ diameter agate balls. Because this equipment had previously been used to powder sediments, which were considered to potentially compromise preparation of the limited samples from this expedition, it was decided to deviate from standard IODP procedure for the preparation and analysis of these samples. The samples were instead sent to the Pacific Centre for Isotopic and Geochemical Research (PCIGR) at the University of British Columbia (Vancouver, Canada) for crushing and powdering with equipment more suitable for analysis of the rock samples collected during Expedition 357: a hydraulic rock crusher (Rocklabs hydraulic crusher) and planetary mill grinder with agate containers (Fritsch planetary mono mill [Pulverisette 6]). Three levels of jars are available at PCIGR - high, medium, and low - and the latter is reserved for processing mafic-ultramafic rock samples. This approach minimized the potential risk of contamination of samples during the various stages of preparation, chemical separation, and analysis. Minimizing contamination is critical because it directly impacts the confidence with which interpretations of the data can be made.

Geological sample crushing requires two important steps: (1) reducing the original sample to maximum fragment sizes less than $5 \mathrm{~mm}$ in diameter and (2) grinding these fragments to form a homogeneous, fine-grained powder smaller than 200 mesh that can be chemically prepared in the laboratory. Crushing a rock to a fine powder always introduces contaminants of some kind, so the goal is to limit the extent of contamination. The first step in grain-size reduction is commonly carried out using a metallic jaw-crusher, a hardened steel mortar and pestle, or by simply wrapping a sample in a plastic sheet and using a hammer. Jaw-crushers physically grind material against steel plates and introduce unacceptably high levels of metal contaminants. The other two percussion-style methods are laborious and awkward, with loss and contamination of sample ma- terial a genuine concern, and are generally ineffective when crushing blocks of solid material. In contrast, hydraulic crushers represent a very efficient method for percussion coarse-crushing of geologic materials with limited contamination under controlled conditions. Samples are repeatedly crushed between a lower stationary plate and a piston-driven upper plate that only moves in the vertical direction (no horizontal movements to induce grinding occur).

The physical action of grinding in the second crushing step results in unavoidable contamination from the container. Grinding rock fragments $(10-100 \mathrm{~g})$ involves either eccentric rotation of a container with rock fragments and a puck and/or ring (e.g., shatterbox or ring mill) or rotation of a grinding bowl containing the fragments and grinding balls about its axis while also orbiting around a central axis (e.g., planetary mill), which causes the balls to collide with the walls and comminute the fragments. Tungsten carbide (WC) containers are commonly used; however, it is established that they introduce not only $\mathrm{W}$ and $\mathrm{C}$, but also significant amounts (parts per million to parts per billion) of $\mathrm{Cr}, \mathrm{Co}, \mathrm{Nb}, \mathrm{Ta}, \mathrm{Re}$, and the platinum group elements (Hickson and Juras, 1986; Frey et al., 1991). Niobium is a particularly useful tracer element, and ratios such as $\mathrm{Nb} / \mathrm{Zr}, \mathrm{Nb} / \mathrm{U}, \mathrm{Nb} / \mathrm{La}$, and $\mathrm{Nb} / \mathrm{Ta}$ have been successfully used to constrain a variety of processes, including the geochemical structure of the mantle and the role of continental crust contamination in basaltic magma (e.g., Arndt and Christensen, 1992; Hofmann, 1997). Use of a WC container also prevents the future application of platinum group element geochemistry and Re-Os isotopic geochemistry for samples ground by this method. To alleviate this major problem, containers made of agate $\left(\mathrm{SiO}_{2}\right)$ are used, which introduces only $\mathrm{Si}$ at the parts per million level. This is an insignificant amount in silicate-based geologic materials where $\mathrm{SiO}_{2}$ contents may range from $\approx 35$ to $80 \mathrm{wt} \%$.

Chemical digestion and separation were carried out in class 100 fume hoods located in a class 1000 clean laboratory, with concentration analyses carried out in class 10000 laboratories at the PCIGR. Acids used for digestion were subboiling distilled in Teflon bottles. $\mathrm{HNO}_{3}$ and $\mathrm{HF}$ were also subboiling distilled in Teflon bottles, whereas $\mathrm{HCl}$ was quartz distilled. Acid blanks were below 10 ppt in subboiled and quartz distilled acids for all elements, except $\mathrm{Cr}, \mathrm{Ni}, \mathrm{Cu}, \mathrm{Zn}, \mathrm{Sr}, \mathrm{Sb}, \mathrm{Ba}$, and $\mathrm{Zr}$, whose values range from 35 ppt to $1.2 \mathrm{ppb}$. All acid dilutions were made with ultrapure Milli-Q water $(18.2 \mathrm{M} \Omega \mathrm{cm})$. Savillex Teflon beakers were acid-cleaned between uses, following four steps: (1) batch cleaning in Extran or Citranox, (2) batch cleaning in $50 \% \mathrm{HCl}$ solution (trace metal grade), (3) batch cleaning in $50 \% \mathrm{HNO}_{3}$ solution (trace metal grade), and (4) fluxing in $50 \% \mathrm{HNO}_{3}-10 \% \mathrm{HF}$ solution. These cleaning steps were $24 \mathrm{~h}$ each on a hot plate at $120^{\circ} \mathrm{C}$.

Major elements were measured using an inductively coupled plasma-optical emission spectrometer (ICP-OES) (Varian 725-ES) at PCIGR. Preparation of each sample and standard is similar to the shipboard method of IODP Expedition 304/305, and the entire procedure took place inside a Pt crucible containing $\approx 5 \% \mathrm{Au}$ to make the container nonwetting. About $100 \mathrm{mg}$ of whole rock powder was mixed thoroughly with $1 \mathrm{~g}$ of $\mathrm{LiBO}_{2}$, and two drops of $25 \% \mathrm{LiBr}$ solution were added to the mixture before it was dried down on a hotplate. At this time, the Pt crucible was inserted with Pt-tipped tongs into a Katanax K-prime automatic fluxer where a Pt lid was already inserted. The sample was fused at $\approx 1000^{\circ} \mathrm{C}$ in the fluxer for $\approx 5 \mathrm{~min}$. Once fused, the resulting glass was quenched in a $40 \mathrm{~mL}$ bath of $10 \% \mathrm{HCl} / 10 \% \mathrm{HNO}_{3}$, which was placed on a stir plate until all of the glass pieces were dissolved. As this solution was trans- 
ferred into a $60 \mathrm{~mL}$ sample bottle, it was rinsed from its container and diluted further with $10 \% \mathrm{HCl} / 10 \% \mathrm{HNO}_{3}$ to $50 \mathrm{~mL}$. Samples were run within $48 \mathrm{~h}$ of their preparation. Loss on ignition was determined by combustion at $1000^{\circ} \mathrm{C}$ on $\approx 1 \mathrm{~g}$ of sample in the commercial laboratory ALS Canada Ltd.

Eight reference materials were used to construct calibration curves during major element analysis (AGV-2, JB-1a, JGb1, JR-1, MRG-1, SY-4, GXR-3, and 88a), and two procedural blanks were analyzed as well. All reference materials and blanks were processed identically and alongside the samples to ensure a matched matrix. Additional reference materials BIR-1a, BHVO-2, and JA-2 were also analyzed and compared to published values (Flanagan, 1984; Wilson, 1997; Imai et al., 1995). Each analysis included Si, Fe, Mg, Mn, $\mathrm{Al}, \mathrm{Ca}, \mathrm{Na}, \mathrm{Ti}, \mathrm{K}$, and $\mathrm{P}$, and a $10 \mathrm{ppm}$ Eu internal standard was used to monitor and correct for instrumental drift. Analyses of the reference materials and wavelengths that were analyzed are reported in X357_Geochem.xlsx in GEOCHEM in Supplementary material.

Trace element contents were determined using a high-resolution inductively coupled plasma-mass spectrometer (H-ICP-MS) (Thermo Finnigan Element 2) at PCIGR (Carpentier et al., 2013; Schudel et al., 2015). About $100 \mathrm{mg}$ of powder was dissolved in a $\mathrm{HF}-\mathrm{HNO}_{3}$ mixture in Savillex vials for 2 days at $130^{\circ} \mathrm{C}$. Samples were then dried on a hot plate and taken up in $6 \mathrm{M} \mathrm{HCl}$ on the hot plate at $120^{\circ} \mathrm{C}$ overnight. The digested samples were dried again on a hot plate and finally diluted $\approx 5000$ times in a mixture of $\mathrm{HNO}_{3}$ $1 \%-\mathrm{HF} 0.05 \%$, containing indium (concentration of $10 \mathrm{ppm}$ ), used as an internal standard to monitor instrument drift. The Ko'olau PCIGR reference material was used to perform external calibration on the basis of the concentrations reported in Norman and Garcia (1999). Procedural blanks were measured for each set of analysis. Three samples of Ko'olau were fully duplicated, and their concentrations are given in X357_Geochem.xlsx in GEOCHEM in Supplementary material. The relative differences of concentrations in the duplicate samples are generally lower than 5\%. Analytical precision for trace element concentrations, evaluated by duplicate analysis, is typically $<5 \%$ RSD for the rare earth elements $\mathrm{Ba}, \mathrm{Zr}, \mathrm{Hf}, \mathrm{Cs}, \mathrm{Nb}, \mathrm{Rb}$, $\mathrm{Ga}, \mathrm{Cu}, \mathrm{Ni}, \mathrm{Co}$, and $\mathrm{V}$ and $<10 \% \mathrm{RSD}$ for $\mathrm{Li}, \mathrm{Mo}, \mathrm{Cd}, \mathrm{Sn}, \mathrm{Sb}, \mathrm{Ta}, \mathrm{W}$, $\mathrm{Bi}, \mathrm{Th}, \mathrm{Sr}, \mathrm{Pb}, \mathrm{U}, \mathrm{Sc}$, and $\mathrm{Y}$.

\section{Total carbon, total inorganic carbon, and total organic carbon analyses}

TC, TIC, and total organic carbon (TOC) samples were collected in two ways. One suite of 10 samples was collected from billets that were cut with a water-cooled circular saw at sea. Although these samples were used for shipboard analysis of TC, TIC, and TOC, they were not collected in a manner designed to prevent the input of extraneous carbon. Shipboard samples for TC, TIC, and TOC were subsampled offshore from rock cores after they equilibrated to room temperature. WRCs were first cut, and then the exterior was removed by cutting on four sides. The interior portion was used for thin section billets, and an aliquot of the exterior portion was devoted to TC, TIC, and TOC analysis. These were stored in nonsterile plastic bags at room temperature until the OSP in Bremen. Shipboard tap water was used to cool the cutting blade, and it was not rinsed from the cores prior to putting them in plastic bags. In Bremen, the exterior pieces were crushed manually in the bag, potentially transferring some of the carbon of the bag to the samples. They were then further homogenized in an ethanol-cleaned agate mortar and pestle. Several of the samples were additionally milled with agate balls. On one sample, markings from a wax pen were still visible. This was removed with fine-grained sandpaper prior to homogenization. The homogenized samples were stored in bottles that were not treated to remove organic carbon (e.g., combusting glassware at $500^{\circ} \mathrm{C}$ using acid-washed, Teflon-lined caps). At certain stages, such as during the homogenization of the sample processing in Bremen, care was taken to not further contaminate these samples by wearing gloves and cleaning surfaces that would come into contact with the core with solvent. This was not done throughout the life cycle of these samples, however, and it is feasible that they were touched by bare hands at some point.

TC, TIC, and TOC concentrations were measured on the 10 shipboard samples using a LECO CS-300 carbon-sulfur analyzer at the University of Bremen. First, about $65 \mathrm{mg}$ of the homogenized sample was weighed in a ceramic cup and heated in a furnace. Evolved $\mathrm{CO}_{2}$ and $\mathrm{SO}_{2}$ were measured with a nondispersive infrared detector to measure the sedimentary TC and total sulfur content. Crushed samples ( $\approx 65 \mathrm{mg}$ ) were also decalcified using $12.5 \% \mathrm{HCl}$ and measured as above. TIC was calculated by subtracting the decalcified fractions from the TC fraction. All values are reported in dry weight percent (wt\%) with an analytical precision less than $3 \%$. Because these samples were not collected in a manner to sufficiently avoid external carbon contamination, reported values should be viewed with extreme caution and considered maximum concentrations.

\section{Postexpedition bulk rock organic chemistry analyses}

\section{Bulk carbon analysis on science party samples}

A second set of shipboard samples from the WRC microbiology samples were collected specifically to minimize potential carbon contamination so as to preserve the in situ TC signature of the cores (see Microbiology). Microbiology samples were wrapped in acidwashed Teflon sheeting, stored frozen, and shipped to the Kochi Core Center (Japan). There, the outside of the cores was carefully removed, and the internal material was crushed and homogenized using solvent-cleaned equipment. A portion of the external material was also sampled for comparison purposes. An aliquot of the homogenized material was freeze-dried in a low-carbon freeze drier outfitted with a scroll pump to eliminate oil vapor contamination. This material will be analyzed for TC, TIC, and TOC at the Swiss Federal Institute of Technology in Zürich (ETH-Zürich; Switzerland) as postexpedition research following methods outlined by Schwarzenbach et al. (2013). TC content will be measured on a coulometer via combustion at $950^{\circ} \mathrm{C}$ and detection of the subsequent $\mathrm{CO}_{2}$. TIC content will be measured on the same coulometer by reacting the bulk powder with perchloric acid in glass capsules and measuring the subsequent $\mathrm{CO}_{2}$. The $\delta^{13} \mathrm{C}_{\mathrm{TC}}$ will be measured on an elemental analyzer-isotope ratio mass spectrometer (EAIRMS). Samples for $\delta^{13} \mathrm{C}_{\mathrm{TIC}}$ and $\delta^{18} \mathrm{O}_{\mathrm{TIC}}$ will be analyzed by GasBench/isotope ratio mass spectrometry. To determine the concentrations and isotope signatures of organic carbon in the samples, aliquots will be transferred to high-walled glass vials with Teflonlined caps and decarbonated with $2 \mathrm{M}$ hydrochloric acid (Lang et al., 2013). Samples will be allowed to sit overnight, and then the liquid will be decanted and more $2 \mathrm{M} \mathrm{HCl}$ will be added. This process will be repeated until no further bubbling is observed on addition of the acid. The residue will be rinsed with Milli-Q water, centrifuged, separated from the liquid, and dried at $60^{\circ} \mathrm{C}$. After homogenization, it will be analyzed for TOC concentrations and isotopes by EAIRMS with a thermal conductivity detector inline to allow the \% TOC to be simultaneously determined. 


\section{Lipid biomarkers}

Aliquots of homogenized samples will be solvent-extracted using a combination of methanol, dichloromethane, and phosphate buffer. The liquid will be concentrated under vacuum and dried under $\mathrm{N}_{2}$. The total lipid extract will be separated into distinct fractions over silica gel. If needed, the fractions will be derivatized to make the compounds amendable for gas chromatography (GC). The compounds will be identified by GC-mass spectrometry and quantified by $\mathrm{GC}$-flame ionization detection.

\section{Amino acids}

Concentrations of free and hydrolizable amino acids will be determined for aliquots of the homogenized samples following the protocol of Cowie and Hedges (1992b).

\section{Fluid inorganic chemistry analyses Offshore ephemeral fluid inorganic chemistry analyses}

Sensor package Niskin bottle samples, CTD Niskin bottle samples, and interstitial fluid samples were analyzed on board for $\mathrm{pH}$, alkalinity, ammonium, and salinity following standard procedures used in previous MSP expeditions (see Water sampling and sensor package data). Sample analyses for $\mathrm{pH}$, alkalinity, and salinity were performed within $48 \mathrm{~h}$ of sample collection, and analyses for ammonium were performed within 24-48 h.

$\mathrm{pH}$ was measured on $0.5 \mathrm{~mL}$ of sample using an ion-specific electrode (Mettler Toledo) with a two-point calibration (standards at $\mathrm{pH} 4$ and 7). The same sample was then used to measure alkalinity by single-point titration to $\mathrm{pH} 3.95$ with $0.01 \mathrm{M} \mathrm{HCl}$ according to standard procedures (Grasshoff et al., 1983). Unexpected values in the offshore $\mathrm{pH}$ and alkalinity measurements prompted reassessment, and where possible, reanalysis of these parameters was performed during the onshore phase of the expedition, as described below.

Ammonium was measured by conductivity, after separation as $\mathrm{NH}_{3}$ through a polytetrafluoroethylene (PTFE) membrane in a flow-through system. In the latter technique, modified after Hall and Aller (1992), ammonia is stripped from a $100 \mu \mathrm{L}$ sample by an alkaline carrier solution $(0.2 \mathrm{M}$ sodium citrate in $10 \mathrm{mM} \mathrm{NaOH})$, passed through a $200 \mathrm{~mm} \times 5 \mathrm{~mm}$ PTFE membrane, and redissolved as $\mathrm{NH}_{4}{ }^{+}$in an acidic solution $(1 \mathrm{mM} \mathrm{HCl})$. Ammonium ions are then measured as the resulting change in conductivity signal in the acidic carrier in a microflow-through cell.

Salinity was determined by optical refraction (Krüss Optronic digital refractometer DR 6200), calibrated with International Association for the Physical Sciences of the Oceans (IAPSO) seawater standards with salinities of $10,30,35$, and 38 practical salinity units (PSU).

Subsamples for cations, trace elements, anions, and sulfide were stored at $4^{\circ} \mathrm{C}$ for further onshore analysis in Bremen through ICPOES (for $\mathrm{Li}, \mathrm{Na}, \mathrm{K}, \mathrm{Mg}, \mathrm{Ca}, \mathrm{Sr}, \mathrm{Ba}, \mathrm{Mn}, \mathrm{Fe}, \mathrm{B}, \mathrm{Si}, \mathrm{S}, \mathrm{P}, \mathrm{Al}$, and $\mathrm{Ti}$ ), ion chromatography (for chlorinity, bromide, sulfate, nitrate, and fluoride), and spectrophotometry (sulfide).

\section{Onshore OSP standard fluid inorganic chemistry analyses}

\section{Cations and trace metals}

A total of 38 filtered $(0.2 \mu \mathrm{m})$ and acidified $(10 \mu \mathrm{L}$ of concentrated $\left.\mathrm{HNO}_{3} / \mathrm{mL}\right)$ samples from the sensor package Niskins $(N=$ 14), CTD rosette Niskins $(N=18)$, and interstitial waters $(N=6)$ were analyzed for cations and trace metals using analytical equipment at the University of Bremen. All samples were diluted 10-fold with $1 \% \mathrm{HNO}_{3}$ and analyzed for major and minor elements. An aliquot of $2 \mathrm{~mL}$ diluted sample was first taken for premeasurement to establish the rough concentrations in the elements of interest and to make standard solutions for both cation and anion analyses. All measurements were done on the same day with the same standard calibration.

Major elements (Al, B, Ba, Ca, Fe, K, Mg, Mn, Na, P, S, Si, Sr, and Ti) were analyzed using a Varian Vista Pro CCD ICP-OES equipped with a SeaSpray nebulizer and a cyclone spray chamber. A $4 \mathrm{~mL}$ aliquot of the 10-fold diluted sample was injected three times. Minor elements (Al, As, Ba, Be, Cd, Ca, Cr, Cu, Fe, Li, Mn, Mo, Ni, P, Pb, $\mathrm{Rb}, \mathrm{Sr}, \mathrm{Ti}, \mathrm{V}, \mathrm{Zn}$, and $\mathrm{Zr}$ ) were analyzed using an Agilent 700 Series ICP-OES equipped with a K-style conical nebulizer. A second $4 \mathrm{~mL}$ aliquot of the 10-fold diluted sample was injected three times for the minor/trace element analyses. The effect of the seawater matrix was assessed by doping the standard solutions with $\mathrm{Na}, \mathrm{SO}_{4}, \mathrm{Ca}, \mathrm{Mg}$, and $\mathrm{K}$ to mimic the concentrations found in the samples.

For both major and minor elements, standardization was performed against multielement solutions prepared from commercial standards with a $1 \% \mathrm{HNO}_{3}$ matrix (as all samples had comparable concentrations close to seawater). Five concentration levels bracketing the concentrations of the samples were used for the multielement standard (dilution factors of 1:1, 1:1.25, 1:2, 1:4, and 1:5) (see figures in GEOCHEM in Supplementary material). External calibration standards were prepared using IAPSO seawater, which was analyzed four times. Estimated measurement precision was $\pm 2 \%$ for major elements and $\pm 5 \%$ for trace elements (very dependent on the element and matrix). Three samples were prepared in duplicate (one CTD Rosette Niskin sample, one interstitial fluid sample, and one sensor package Niskin sample) and analyzed as separate samples to determine reproducibility; all duplicates were equal within uncertainty.

For trace element analyses, few elements were above the detection limit: $\mathrm{Li}, \mathrm{Al}, \mathrm{Ba}, \mathrm{Fe}$, and $\mathrm{Mn}$ (not all samples were above detection for $\mathrm{Mn}$ ). All the other elements analyzed (As, Be, Cd, Co, Cr, $\mathrm{Cu}, \mathrm{Mo}, \mathrm{Ni}, \mathrm{P}, \mathrm{Pb}, \mathrm{Rb}, \mathrm{Ti}, \mathrm{V}$, and $\mathrm{Zr}$ ) were below detection limits (see figures in GEOCHEM in Supplementary material). On the basis of the standard solutions analyzed, the sample concentrations are $<2$ ppb. Zinc has concentrations above the detection limit but appears to reflect contamination due to uncharacteristically high values. Results are consistent between holes for all sites. For elements analyzed on both ICP-OES instruments, reported values are from the Varian Vista Pro (major element analyses), with the exception of Al.

\section{Anions}

A total of 38 filtered and unacidified samples (sensor package Niskins $[N=14]$, CTD rosette Niskins $[N=18]$, and interstitial waters $[N=6]$ ) were analyzed for anions (chloride, bromide, sulfate, nitrate, and fluoride) using a Metrohm 882 Compact ion chromatograph with an 858 Professional sample processor at the University of Bremen. Anions were separated over a Metrosep A Supp 5 column $(150 \mathrm{~mm} \times 4.0 \mathrm{~mm}, 5 \mu \mathrm{m}$ particle size $)$ and two guard columns, a Metrosep A Supp 4/5 (4.0 mm) and a Metrosep RP2 Guard 3.6 column. The mobile phase was held constant at $0.7 \mathrm{~mL} / \mathrm{min}$ and contained $3.2 \mathrm{mmol} / \mathrm{L}$ sodium carbonate $\left(\mathrm{NaCO}_{3}\right)$ and $1.0 \mathrm{mmol} / \mathrm{L}$ sodium bicarbonate $\left(\mathrm{NaHCO}_{3}\right)$. A 40-fold dilution of IAPSO seawater and a dilution curve of a mixed standard solution were used for calibration. Measurement precision on the basis of the concentrated standard was $\pm 0.1 \%$ for $\mathrm{Cl}, \pm 5 \%$ for $\mathrm{Br}, \pm 1.1 \%$ for $\mathrm{SO}_{4}, \pm 0.2 \%$ 
for $\mathrm{NO}_{3}$, and $\pm 2.0 \%$ for $\mathrm{F}$ based on two standard deviations of the measurement (see figures in GEOCHEM in Supplementary material). For the IAPSO seawater reference solution, precisions were $\pm 3.9 \%$ for $\mathrm{Cl}, \pm 2.2 \%$ for $\mathrm{Br}$, and $\pm 4.3 \%$ for $\mathrm{SO}_{4}$, whereas both $\mathrm{NO}_{3}$ and $\mathrm{F}$ were below the limit of detection.

\section{Sulfide}

Total sulfide was measured for 41 samples following the spectrophotometry method of Cline (1969). In short, dimethyl-pphenylene-diamine forms an intermediate complex with hydrogen sulfide that transforms to leucomethylene blue, which is oxidized to methylene blue by ferric iron. Sulfide is volatile, so samples and standards were preserved as quickly as possible after collection at sea (see Water sampling and sensor package data). A concentrated solution of zinc acetate was added, causing sulfide to precipitate as zinc sulfide. N,N-dimethyl-1,4-phenylenediaminedihydrochloride and $\mathrm{FeCl}_{3} \cdot 6 \mathrm{H}_{2} \mathrm{O}$ were used as color reagent and oxidizing agent, respectively. Samples were analyzed using a DR 5000 spectrophotometer at University of Bremen. The extinction was measured on wavelength 670 after 30 min reaction time. For all samples, concentrations were below the detection limit, so results of this analysis are not presented in the site chapters.

\section{Stable carbon isotope composition of dissolved inorganic carbon}

Fluids were preserved offshore for stable carbon isotope analysis of dissolved inorganic carbon (DIC) (see Water sampling and sensor package data). The carbon isotope composition of $\mathrm{CO}_{2}$ in the headspace of the sample vials was measured at the Stable Isotope Laboratory of the Geological Institute, ETH Zürich, using a Thermo Fisher Scientific GasBench II coupled to a Delta V mass spectrometer. The instrument was calibrated with the international reference materials NBS $19\left(\delta^{13} \mathrm{C}=+1.95 \%\right)$ and NBS $18\left(\delta^{13} \mathrm{C}=-5.05 \%\right)$ and solutions of an internal laboratory sodium bicarbonate standard prepared in concentrations bracketing those observed in the samples. Isotope values are reported in conventional delta notation with respect to Vienna Peedee belemnite (VPDB).

\section{Onshore pH and alkalinity}

Residues of water samples from sensor package Niskins $(N=$ 14), CTD rosette Niskins $(N=18)$, and interstitial waters $(N=6)$ were analyzed for alkalinity at the University of Bremen using the same $\mathrm{pH}$ meter and autotitrator used at sea. The accuracy of the meter was tested against standards of known alkalinities, including $\mathrm{Na}_{2} \mathrm{~B}_{4} \mathrm{O}_{7} \cdot \mathrm{H}_{2} \mathrm{O}$ (10 mM for an alkalinity of $20 \mathrm{mM}$ ), $\mathrm{NaHCO}_{3}$ (25 and $50 \mathrm{mM}$ for alkalinities of 25 and $50 \mathrm{mM}$, respectively), and IAPSO seawater $(\approx 2.325 \mathrm{mM})$ according to the procedure of Gieskes et al. (1991). All standards were dissolved in $\mathrm{a} \approx 0.7 \mathrm{M}$ solution of $\mathrm{KCl}$ which serves as an ionic-strength preserver. Initial alkalinity readings were higher than expected, possibly due to insufficient mixing of the sample with titration acid. After correcting this issue, multiple replicates of freshly opened IAPSO seawater were analyzed with each group of samples and used to adjust the expected and real acid concentration (Rounds, 2012). The standards of $\mathrm{Na}_{2} \mathrm{~B}_{4} \mathrm{O}_{7} \cdot \mathrm{H}_{2} \mathrm{O}$ and $\mathrm{NaHCO}_{3}$ were also analyzed with each group and were consistently within $5 \%$ of expected values. The final, corrected value of IAPSO seawater was $2.33 \pm 0.02 \mathrm{mM}$ alkalinity. Replicates of eight separate CTD and sensor package samples had reproducibility of $\pm 0.08 \mathrm{mM}$ alkalinity.

\section{Microbiology}

The primary microbiology objective for Expedition 357 was to explore the extent and activity of the subsurface biosphere in young ultramafic and mafic seafloor, focusing on the potential for a hydrogen-based deep biosphere in an area undergoing active serpentinization (Früh-Green et al., 2015). Drilling, sampling, and analysis were designed to test the following of the expedition's hypotheses:

- An extensive subsurface hydrogen-based biosphere persists in the serpentinizing lithosphere. These communities evolve and adapt to variations in diffuse flow, fluid chemistry, heat flow distribution, and aging of the seafloor.

- Serpentinizing environments sustain higher biomass than gabbroic-dominated domains.

- The transition from sulfide- to carbonate-dominated environments can be detected by changes in the associated microbial communities.

- Zones of intense carbonate veining underlie sites of diffuse venting and represent seawater recharge and net sequestration of $\mathrm{CO}_{2}$ from the hydrosphere to the lithosphere. These zones are biological hotspots where microbial communities are supported by the high fluxes of $\mathrm{H}_{2}$ mixing with $\mathrm{CO}_{2}$.

This section focuses on shipboard methods used for sample collection and handling for microbiological analyses from core samples. Additional seawater samples for microbiological analysis are described in Water sampling and sensor package data. Samples of core collected for microbiology were subsampled for environmental nucleic acid extraction and analysis, cell detection and enumeration, contamination tests, lipid biomarker analysis, and several enrichment and culturing experiments. Some preparations were conducted shipboard, but science party members will conduct the majority of the analyses in shore-based laboratories. Because this was the first IODP expedition to use seabed drills, several established methodologies for microbiological sampling (e.g., those used during Integrated Ocean Drilling Program Expeditions 327, 329, and 336 [Expedition 327 Scientists, 2011; Expedition 329 Scientists, 2011; Expedition 336 Scientists, 2012]) were adapted to the constraints and opportunities that this drilling approach required.

\section{Analysis of potential contamination with PFC tracer}

The use of tracers in drilling fluids to monitor for potential contamination of samples for microbiological analysis is critical and has become routine during microbiology-focused expeditions (Inagaki et al., 2015; Lever et al., 2006, 2013; Smith et al., 2000). PFC has been identified as an ideal tracer because of the large range of concentrations that are detectable (i.e., across six orders of magnitude) through volatile detection with a GC equipped with an electron capture detector (GC-ECD) (Lever et al., 2006; Smith et al., 2000). Therefore, we sought to use PFC tracer during drilling with the seabed drills.

During traditional drilling, drilling fluids (muds) are prepared on the platform and injected into the drill pipe, and the concentration of PFC tracer delivered into the flush water can be closely monitored and adjusted to reach saturating conditions (roughly $1 \mathrm{mg} / \mathrm{L}$ ). In contrast, seabed drills use bottom seawater directly as flushing water. Therefore, we developed an in situ method for delivering 
concentrated PFC tracer directly into the line of the flushing water on the rock drill. In brief, the system was designed to deliver roughly $50 \mu \mathrm{L} / \mathrm{min}$ of pure PFC solution (Sigma Aldrich) directly into the stream of flushing water to achieve a saturating concentration of roughly $1 \mathrm{mg} / \mathrm{L}$ for a flushing rate of $50 \mathrm{~L} / \mathrm{min}$. This system consists of a small precision variable-controlled pump (Mikro systemz F-PV Modul), an ON/OFF 2/2 shift valve, an electronic controller, and a replaceable bag of tracer fluid (Figure F17). The electronics were housed in a custom-made pressure-compensated housing of galvanized steel. The system was mounted onto each drill and controlled from the surface via an independent RS232 serial communication link to the subsea tracer controller. The pump flow rate was adjustable in the range 0.015 to $5 \mathrm{~mL} / \mathrm{min}$ to match the flush flow rate for each drill, and the pump flow rate was initially calculated based on the flush rate and the required concentration of tracer. The flush rate on the rock drills varied throughout operations but tended to range from 20 to $50 \mathrm{~L} / \mathrm{min}$.

Figure F17. Drill-mounted tracer injection system, shown on the MeBo drill, Expedition 357. The silver box is oil filled, with internal oil pressure maintained by the black compensator. The pump head and tracer feed sit inside the box, and the main controlling electronics sit in the silver pressure canister. The replaceable tracer fluid bag that feeds into the pump system is not shown. Image courtesy of Tim Freudenthal.

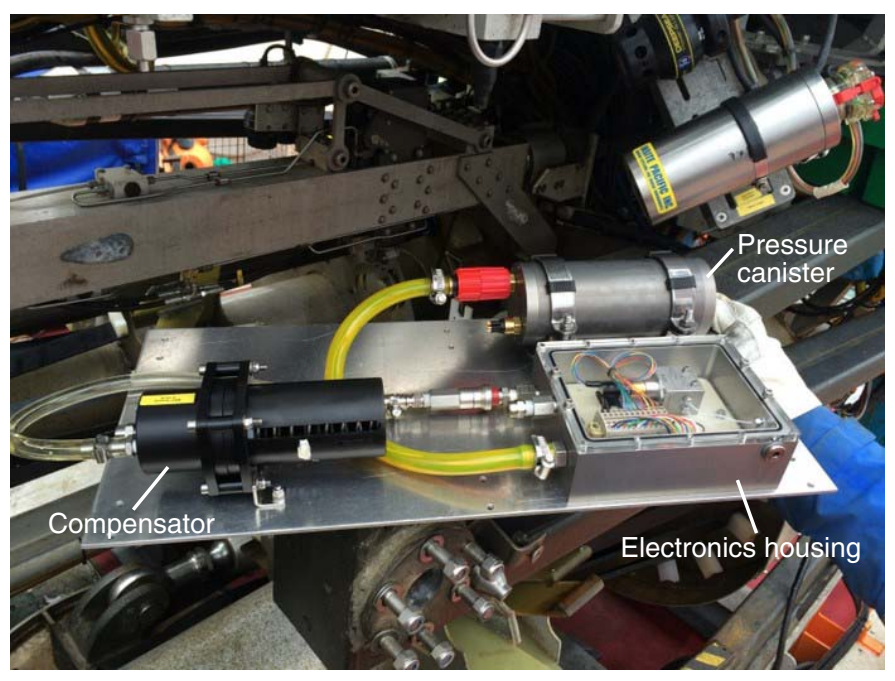

Throughout the expedition, pumping rate and performance varied, affecting the volume of PFC tracer that was actually delivered during operations at each hole. Tests for PFC concentrations on samples obtained from the first holes, as described in Microbiology in the Eastern sites chapter (Expedition 357 Scientists, 2017), revealed that the concentrations achieved were well below those expected and required. Increasing pump rates to achieve the desired tracer concentration were unsuccessful. Dismantling one of the pumps identified that the internal rubber paddle, responsible for opening and closing the valve supplying the PFC tracer, was swollen to almost twice the size it should have been, thus blocking supply. Laboratory tests were undertaken and it was ascertained that the swelling of the rubber paddle was not an adverse reaction to the tracer fluid. The paddle was shaved to reduce its size, and the pump system was put back together. Concentrations in fluid samples acquired after this modification were much improved, and pumping rates for tracer injection were consequently reduced. Pumping rates for each hole are shown in Table T4.

Because of this variability in tracer pump delivery, it was not possible to convert PFC concentrations observed in the samples into the volume of flushing water potentially contaminating the core, as is commonly done (Lever et al., 2006; Smith et al., 2000; Inagaki et al., 2015). Therefore, for this expedition, concentrations are reported simply as the amount of PFC tracer per volume of sample.

To monitor PFC delivery, a variety of samples were collected from the rock drills after drilling: liner fluid samples, sensor package Niskin bottle samples, and exterior and interior core samples. The sample type referred to as "liner fluid" represents a mixture of bottom water that was in the core barrel prior to being replaced by core, as well as flushing water collected during coring. Liner fluids were collected by either draining from the ball valve at the top of the core prior to opening the core barrel to recover the core inside or by draining at the lower end of the core before retracting the core liner from the core barrel. In either case, fluids were collected in a sterile $50 \mathrm{~mL}$ centrifuge tube, and then $10 \mathrm{~mL}$ of this fluid was immediately transferred to a $22 \mathrm{~mL}$ glass headspace vial and crimp sealed. For sensor package samples, $10 \mathrm{~mL}$ fluid samples were collected from each of the three rock drill-mounted Niskin bottles, which sampled the fluids flushed out of the borehole near the breakout table and bottom seawater. For core samples, when cores were transferred to the shipboard laboratory to select WRCs for ephemeral microbiological analyses, $1-5 \mathrm{~cm}^{3}$ of core in the form of small fragments was

Table T4. PFC pump rate for each hole drilled during Expedition 357. Download table in .csv format.

\begin{tabular}{lccccl}
\hline Order & $\begin{array}{c}\text { Proposed } \\
\text { site }\end{array}$ & Site & Hole & $\begin{array}{c}\text { PFC pump speed } \\
\text { (rpm) }\end{array}$ & \multicolumn{1}{c}{ Comments } \\
\hline 1 & AM-02 & M0068 & A & 50 & \\
2 & AM-06 & M0069 & A & 50 & \\
3 & AM-07 & M0070 & A & 55 & \\
4 & AM-04 & M0071 & A & 55 & \\
5 & AM-01 & M0072 & A & 100 & \\
6 & AM-01 & M0072 & B & 100 & MeBo \\
7 & AM-07 & M0070 & B & 1500 & MeBo \\
8 & AM-05 & M0073 & A & 1500 & MeBo; tracer bag inverted for tracer to drain downward \\
9 & AM-11 & M0076 & A & 1500 & \\
10 & AM-11 & M0076 & B & 1500 & Pumping only occurred during core Run 1 \\
11 & AM-04 & M0071 & B & 1500 & Pump modified by shaving down the internal rubber paddle \\
12 & AM-07 & M0070 & C & 100 & \\
13 & AM-02 & M0068 & B & 100 & Pump not operational on core Run 4 because of technical problems \\
14 & AM-04 & M0071 & C & 50 & \\
15 & AM-03 & M0075 & A & 50 & \\
16 & AM-03 & M0075 & B & 50 & \\
17 & AM-09 & M0074 & A & 50 & \\
\hline
\end{tabular}


transferred to $22 \mathrm{~mL}$ glass headspace vials containing $5 \mathrm{~mL}$ of distilled water and crimp sealed. These represented the exterior of the core. After flame-sterilization of WRC pieces (see Pooled frozen rock samples), interior samples for PFC analysis were collected in a similar manner using a flame-sterilized hammer and chisel to generate fragments from the interior of the flamed WRC piece. Care was taken to conduct the flame-sterilization step, which would volatilize the PFC tracer into the laboratory atmosphere, in a separate laboratory from where the samples were prepared to minimize the risk of false positives.

After collection, the exterior of crimped headspace vials were rinsed with copious amounts of water, dried, and then heated in a $70^{\circ} \mathrm{C}$ oven for several hours prior to analysis. At the same time, a set of PFC standards was prepared under a fume hood in the same type of vials and also heated in the oven, following established tracer dilution protocols (Smith et al., 2000). It is important to note that the fume hood vented into the laboratory after passing through a filter (i.e., it did not vent to the exterior of the ship), and both the oven and the GC-ECD used for analysis also vented into the room; this led to a buildup of PFC tracer in the atmosphere of the analysis laboratory over time. Care was taken to conduct thorough analysis of the atmospheric concentration of PFC tracer in all laboratories during analyses, both from air samples collected directly into syringes during GC-ECD analysis and from headspace vials closed in the laboratories during sample collection, to account for the possibility of false positives.

PFC tracer analysis followed established protocols (Lever et al., 2006; Smith et al., 2000). Using a heated disposable plastic $3 \mathrm{~mL}$ syringe fitted with a two-way stopcock and $51 \mathrm{~mm}, 22$ gauge Hamilton needle, a $2 \mathrm{~mL}$ headspace sample from either sample or standard vials was injected into the splitless injector on the Agilent 7890A GC system GC-ECD. The GC-ECD was equipped with a 30 $\mathrm{m}$ length $\times 53 \mu \mathrm{m}$ inner diameter $\times 15 \mu \mathrm{m}$ coating thickness Agilent $\mathrm{HP}-\mathrm{AL} / \mathrm{M}$ column run with ultrahigh-purity nitrogen carrier gas at $4.7 \mathrm{psi}(57 \mathrm{~mL} / \mathrm{min})$ with an initial column temperature of $120^{\circ} \mathrm{C}$ for $0.5 \mathrm{~min}$, followed by a $50^{\circ} \mathrm{C} / \mathrm{min}$ ramp to $200^{\circ} \mathrm{C}$ for $2.2 \mathrm{~min}$. The injector temperature was set at $175^{\circ} \mathrm{C}$. Under these parameters, the PFC peak eluted at roughly $3.4 \mathrm{~min}$ as monitored with Agilent ChemStation Rev B.03.03 software. The concentrations of PFC tracer in samples were determined by comparing the peak area to a standard curve of peak area versus PFC tracer injected from the standards. Based on duplicate analysis of standards, the limit of detection was $2 \times 10^{-12} \mathrm{~g}(2 \mathrm{pg})$ PFC, which is in the range of what was determined previously (Smith et al., 2000; Lever et al., 2006).

\section{Pooled frozen rock samples}

As described in Core handling during the Expedition 357 offshore phase, the general strategy for selection of WRC for microbiological investigation was to select a representative section from one end of every other core section, starting with core sections from the base of the borehole. From each WRC, a 2-20 cm section was set aside for pooled analyses to be completed on shore. The piece was typically divided into two portions labeled "flamed" and "unflamed." For the flamed sample, the exterior of the piece was flamesterilized using a handheld butane torch inside a flame-sterilized steel box. Both pieces were then separately wrapped in acid-cleaned and autoclaved $0.4 \mathrm{~mm}$ thick Teflon sheeting, transferred to sterile Whirl-Pak bags, and frozen at $-80^{\circ} \mathrm{C}$. Teflon sheeting was used to minimize transfer of organic carbon from the Whirl-Pak bags onto the samples. On shore, the frozen pieces were subsampled and homogenized while still frozen under clean air conditions at the Kochi
Core Center. Splits of the homogenate were distributed for numerous shore-based analyses, including nucleic acid extraction, lipid biomarker analysis, carbon isotope analyses, and bulk rock XRD.

Nucleic acid extraction from homogenized core material will be conducted on shore at the University of Utah (USA) following a protocol developed for low-biomass rocks adapted from strategies used on hydrothermal sulfides, carbonate chimneys, serpentinites, and basalts (Schrenk et al., 2003; Brazelton et al., 2010; Lever et al., 2015; Twing, 2015; Barton et al., 2006).

\section{Cell detection and enumeration}

Cell detection and enumeration from sediment and rock samples were determined shipboard through epifluorescence microscopy following modification of previously published methods (Morono et al., 2009, 2013). To evaluate the risk of potential background contamination during drilling, various seawater and fluid samples were collected and enumerated, including bottom seawater collected from casts of the ship's CTD Niskin rosette; Niskin bottles on the rock drills; and liner fluids from the core barrels.

Rock samples for cell enumeration were taken from both the exterior and interior of the WRC pieces, with the interior pieces collected using flame-sterilized tongs after flaming the exterior of the WRC with a butane torch until dry. Roughly $5 \mathrm{~cm}^{3}$ pieces of rock were transferred to combusted aluminum foil and stored at $4^{\circ} \mathrm{C}$ until processing. Pieces were broken and crushed into millimetersized grains using a sterilized metal mortar and pestle within the confines of a $\mathrm{KOACH}$ laminar flow unit (Table $\mathrm{KOACH}$, Koken, Ltd.). The metal mortar and pestle were cleaned by rinsing with distilled water, spraying with RNase AWAY, letting soak for a few minutes, and finally flaming. A total of $4 \mathrm{~cm}^{3}$ of crushed material was mixed with $9 \mathrm{~mL}$ of $1 \times$ phosphate buffered saline $(\mathrm{pH}=7.4$; Ambion $\mathrm{AM} 9624)$ and $1.5 \%[\mathrm{w} / \mathrm{v}] \mathrm{NaCl}$, along with $2 \%[\mathrm{v} / \mathrm{v}]$ neutralized formaldehyde as a fixative (hereafter referred to as fixing solution).

For sediment samples, a $1.5 \mathrm{~cm}^{3}$ sample was taken by a sterile cut-end syringe and pooled directly into the fixing solution. For fluid samples, $5 \mathrm{~mL}$ of sample was mixed with equal volume of fixing solution and vortexed thoroughly to form a homogeneous suspension. The resulting suspension was filtered onto a $25 \mathrm{~mm}$ diameter black $0.22-\mu \mathrm{m}$-mesh polycarbonate membrane filter (GTBP02500; Millipore) using vacuum filtration without further processing. Unfixed samples were frozen with the Cells Alive System (CAS) freezer (LAB-1; ABI Co. Ltd.) for analysis at the onshore laboratory.

The fixed rock or sediment slurries were then subjected to the cell detachment and separation steps (Morono et al., 2009), including procedural negative controls, as follows:

1. Transfer $0.5-2 \mathrm{~mL}$ of the fixed sample to a $15 \mathrm{~mL}$ centrifuge tube.

2. Add $2.5 \% \mathrm{NaCl}$ solution (filter sterilized) for $2.2 \mathrm{~mL}$ total volume (for the negative control, $2.2 \mathrm{~mL}$ of $\mathrm{NaCl}$ was used).

3. Add $400 \mu \mathrm{L}$ of detergent mix (100 mM EDTA, $100 \mathrm{mM}$ sodium pyrophosphate, and $1 \%$ [v/v] Tween 80 ) and $400 \mu \mathrm{L}$ of methanol to each tube (mix thoroughly after the addition of each solution).

4. Vortex tubes at maximum speed for $1 \mathrm{~h}$ (Vortex Genie 2, Scientific Industries).

5. Sonicate tubes in a sonicating bath at $120 / 240 \mathrm{~W}$ for $10 \mathrm{~min}$ (RK105, BANDELIN electronic).

6. Allow large particles to settle briefly, and then load sample suspension on top of prepared step-wise density gradient consisting 
of $1.5 \mathrm{~mL}$ each of (from top) 30\%, 50\%, and 80\% Nycodenz (1002424, WAK-Chemie Medical GmbH) and 67\% sodium polytungstate (SPT0, SOMETU-Europe) solutions.

7. Centrifuge at $7140 \times g$ for $60 \mathrm{~min}$ at $12^{\circ} \mathrm{C}$ (5430R, Eppendorf).

8. Recover supernatant from surface of density gradient using sterile syringe and $26 \mathrm{G}$ needle and transfer to $50 \mathrm{~mL}$ Granier tube.

9. Add $5 \mathrm{~mL} 2.5 \% \mathrm{NaCl}$ solution to remaining heavy density solution and mix thoroughly.

10. Centrifuge density solution again at $7140 \times g$ for $20 \mathrm{~min}$ at $12^{\circ} \mathrm{C}$. 11. Recover supernatant and add to the resulting solution in Step 8.

12. Extract the remaining large particles by adding $2.0 \mathrm{~mL}$ of $2.5 \%$ $\mathrm{NaCl}$ and extract as in Steps 2-10, and then add to resulting solution in Step 8.

13. Filter the combined supernatant onto a $25 \mathrm{~mm}$ diameter black $0.22 \mu \mathrm{m}$ mesh polycarbonate membrane filter (GTBP02500, Millipore) using vacuum filtration.

14. Stain cells on filter with SYBR Green I staining solution (1:40 dilution of SYBR Green I in TrisEDTA buffer).

15. Mount stained filter with Vectashield on glass slide and count cells as described in Morono et al. (2009).

All sample handling steps were performed in a $\mathrm{KOACH}$ open clean system with care to avoid potential contaminants (e.g., dust).

\section{Single-cell sorting}

For shore-based single-cell sorting from rock samples for nucleic acid extraction, roughly $5 \mathrm{~cm}^{3}$ samples from the interior of flamed WRC pieces were transferred to a cold solution of $1 \times$ glycerol-TrisEDTA buffer (1:10 dilution of $10 \times$ buffer [ $20 \mathrm{~mL} 100 \times$ TrisEDTA buffer $\mathrm{pH}$ 8.0, $60 \mathrm{~mL} 18 \mathrm{M} \Omega$ distilled water, and $100 \mathrm{~mL}$ glycerol] in $0.2 \mu \mathrm{m}$ filtered and autoclaved bottom seawater), mixed thoroughly, and frozen. In a shore-based laboratory, microbial cells will be liberated from rock surfaces, concentrated, and sorted using flow cytometry following methods established previously (Stepanauskas and Sieracki, 2007).

\section{Enrichment and incubation experiments}

To fulfill the expedition objectives to understand microbial activity within Atlantis Massif, several different shipboard enrichment experiments were established with WRC material soon after core collection to capture the ephemeral properties of live cells within the samples. In some cases, WRC samples were preserved intact within gas-tight storage bags under anaerobic headspace $\left(\mathrm{N}_{2}\right)$ and stored cold $\left(4^{\circ} \mathrm{C}\right)$ for establishing enrichment experiments in shorebased laboratories under cleaner air conditions than could be established on the ship. In other cases, experiments were set up directly on the ship within nitrogen-sparged glove bags. The following sections describe the variety of incubations experiments that were established by the expedition science party.

\section{Single-cell analysis of carbon and nitrogen assimilation rates of subseafloor microbial communities}

To determine substrate uptake rates of individual microbial cells incubated with stable isotope-labeled substrates using nannoscale secondary ion mass spectrometry in the onshore laboratory, WRC samples were wrapped with sterile Whirl-Pak bags and sealed in gas-impermeable bags together with an oxygen scrubber (AnaeroGen, Thermo Scientific) after flushing with $0.22 \mu \mathrm{m}$ mesh filtered ultrahigh-purity nitrogen gas. Samples were stored at $4^{\circ} \mathrm{C}$ in this way until the experiment in the onshore laboratory. There, samples were homogenized under clean air conditions and distributed for incubation with different stable carbon and nitrogen isotope-labeled substrates following established protocols (Morono et al., 2011).

\section{Potential rate measurements of respiration and methanogenesis in sulfate-reducing microcosm experiments}

WRC samples for potential rate measurements were initially wrapped in a sheet of autoclaved Teflon film and stored in $\mathrm{N}_{2}$ atmosphere in a gas-impermeable bag at $4{ }^{\circ} \mathrm{C}$ until further shipboard processing. Prior to crushing, WRC samples were gently washed twice with autoclaved $3 \%[\mathrm{w} / \mathrm{v}] \mathrm{NaCl}$ solution in a sterile Whirl-Pak bag; the exterior was then flamed to dryness with a butane torch to minimize potential contamination. Inside a $\mathrm{N}_{2}$ filled glove bag, cores were broken into $2-3 \mathrm{~cm}$ sized pieces using a flame-sterilized chisel on a flame-sterilized steel plate; those pieces were then crushed into 5-10 $\mathrm{mm}$ pieces in an autoclaved steel impact mortar and finally ground into 1-3 $\mathrm{mm}$ pieces in an autoclaved metal mortar with pestle. After homogenization, $10 \mathrm{~cm}^{3}$ of material was placed into 160 $\mathrm{mL}$ combusted glass serum vials and capped with chlorobutyl rubber septa. Serum bottles were removed from the glove bag and subsequently flushed with a stream of $\mathrm{N}_{2}$ for $20 \mathrm{~s}$.

Experiments for each treatment were run in triplicate, alongside a "killed" control, produced by autoclaving a serum bottle containing rock powder for $30 \mathrm{~min}$ at $125^{\circ} \mathrm{C}$ and 20 psi. Subsequently, 48 $\mathrm{mL}$ of sterile (autoclaved), anoxic $\left(\mathrm{N}_{2}\right.$ sparged) artificial seawater medium containing the following components was added to each bottle:

- $21.0 \mathrm{~g} / \mathrm{L} \mathrm{NaCl}$,

- $3.1 \mathrm{~g} / \mathrm{L} \mathrm{MgCl}{ }_{2} \cdot 6 \mathrm{H}_{2} \mathrm{O}$,

- $3.0 \mathrm{~g} / \mathrm{L} \mathrm{Na}_{2} \mathrm{SO}_{4}$,

- $1.0 \mathrm{~g} / \mathrm{L}$ CHES buffer,

- $0.5 \mathrm{~g} / \mathrm{L} \mathrm{KCl}$,

- $0.3 \mathrm{~g} / \mathrm{L} \mathrm{NH}_{4} \mathrm{Cl}$,

- $0.2 \mathrm{~g} / \mathrm{L} \mathrm{KH}_{2} \mathrm{PO}_{4}$

- $0.15 \mathrm{~g} / \mathrm{L} \mathrm{CaCl} \cdot 2 \mathrm{H}_{2} \mathrm{O}$,

- $5 \mathrm{~mL}$ Resazurin solution $(0.02 \%[\mathrm{w} / \mathrm{v}])$,

- $5 \mathrm{~mL} / \mathrm{L}$ ATCC trace elements solution, and

- $10 \mathrm{~mL} / \mathrm{L}$ ATCC vitamin solution, pH adjusted to 9.0 with $10 \mathrm{M}$ $\mathrm{NaOH}$, reduced with cysteine- $\mathrm{HCl}$.

Additionally, $1 \mathrm{~mL}$ of $1 \%$ stable carbon isotope labeled substrates (i.e., sodium acetate, sodium formate, sodium bicarbonate, and sodium lactate) at a concentration of $1 \mathrm{M}$ were added to vials, resulting in a final concentration of $20 \mathrm{mM}$ for each carbon-bearing substrate. For methane stable isotope enrichment, a 1\% labeled methane mixture was prepared by mixing the gas in the vial headspace. Samples were equilibrated to $25^{\circ} \mathrm{C}$ for $1 \mathrm{~h}$ before initial time point samples for cell counts $(1.8 \mathrm{~mL}$ culture $+0.2 \mathrm{~mL} 37 \%$ formaldehyde), hydrogen sulfide $(0.2 \mathrm{~mL}$ culture $+1.0 \mathrm{~mL} 1 \%$ zinc acetate solution), and TIC ( $0.5 \mathrm{~mL}$ culture into evacuated Exetainer with 60 $\mu \mathrm{L}$ of $85 \%$ phosphoric acid) were taken.

Finally, $20 \mathrm{~mL}$ of $\mathrm{H}_{2}$ was added to each bottle using a gas-tight syringe, and $10 \mathrm{~mL}$ of $1 \%-{ }^{13} \mathrm{C}$ labeled $\mathrm{CH}_{4}$ in a 50:50 mixture with $\mathrm{N}_{2}$ was added to the methane experiments. Bottles were incubated at $25^{\circ} \mathrm{C}$ for up to 1 month before collecting an additional time point. In addition to the sample types mentioned above, headspace gas from each bottle will be collected at time points to measure the stable isotopic ratio. Samples were shipped to the onshore laboratory at room temperature $\left(20^{\circ}-25^{\circ} \mathrm{C}\right)$. Samples for nucleic acid analysis will be obtained by sacrificing one of the replicate incubations and 
collecting the fluids and solids from the experiments. Nucleic acids will be extracted following the procedures described above and in Water sampling and sensor package data.

\section{Enzyme activity assays}

To determine extracellular enzyme activity in rock samples, as previously done for basalts (Jacobsen Meyers et al., 2014), WRC samples were homogenized and incubated in nitrogen-sparged, $\mathrm{pH}$ 9.0, autoclaved artificial seawater media (as described above) with 4-methylumbelliferyl phosphate (MUF-P). When MUF-P is acted upon by alkaline phosphatase, a fluorescent product is produced, and the level of fluorescence in the incubation is measured in a time series to indicate the amount of substrate cleaved over time. Incubations were set up with a range between 5 and $35 \mu \mathrm{M}$ MUF-P concentrations to enable Michaelis-Menton kinetics (i.e., $K_{\mathrm{m}}$ and $V_{\max }$ ) for the enzyme to be determined. To determine actively growing cells in the same experiments and to aid in single-cell genomics analysis from these experiments, an amino acid ortholog, L-homoproparygylglycine (HPG) was added to the same enzyme assay experiments at a concentration of $130 \mu \mathrm{M}$. Cells actively synthesizing proteins will incorporate the amino acid ortholog into biomass, which can then be identified by microscopy or flow cytometry following fluorescent labeling of the amino acids using "click chemistry" (Hatzenpichler and Orphan, 2015).

For these experiments, the exteriors of intact WRC pieces were flame-sterilized with a butane torch, with the exception of rubbly WRC pieces that were not amenable to flame sterilization. In those instances, WRC pieces were transferred to a sterile Whirl-Pak bag and serially rinsed at least 10 times with $50-100 \mathrm{~mL}$ of filter-sterilized and nitrogen-sparged bottom seawater or media solution (as defined above), to remove potential exterior contamination. Next, WRC pieces were transferred to a nitrogen-sparged glove bag in a $10^{\circ} \mathrm{C}$ cold room and broken into smaller pieces using a flame-sterilized sledge hammer inside a flame-sterilized steel box and then homogenized to millimeter- to centimeter-sized pieces in an autoclaved metal mortar and pestle. Using an autoclaved metal scoop, roughly $20 \mathrm{~cm}^{3}$ aliquots of homogenized sample were transferred to precombusted $60 \mathrm{~mL}$ glass serum vials and mixed with 27 $\mathrm{mL}$ of media. Substrates were added from filter-sterilized anoxic stock solutions, and vials were capped with a nitrogen headspace. At least triplicates were set up for each treatment condition, plus at least two autoclaved killed controls. Vials were incubated without agitation in the dark at $10^{\circ}-12^{\circ} \mathrm{C}$. At each time point, vials were opened inside a nitrogen-sparged glove bag in the cold room and $1.5 \mathrm{~mL}$ of solution was withdrawn from each vial, transferred to a 2 $\mathrm{mL}$ centrifuge tube, and frozen until shore-based analysis of enzyme activity. At the end of the experiment, the remaining fluid and rocks were frozen for shore-based single-cell enumeration and nucleic acid analysis.

\section{Piezophilic and alkaliphilic anaerobic cultivations}

After flaming the exterior of the WRC rock piece over a Bunsen burner to remove potential surface contaminants, the core sample was broken into small pieces with a flamed chisel. Rock fragments were manipulated with sterile forceps and crushed to sand-sized fragments using a stainless steel mortar and pestle under flame-induced and low-oxygen anaerobic conditions. For sediment samples collected in sterile cut-end $10 \mathrm{~cm}^{3}$ plastic syringes, the sediment was directly transferred to enrichment tubes as described below.

High-pressure enrichments will be used to select for piezophilic (high pressure-adapted) microorganisms using high-pressure ves- sels (Tamburini et al., 2013). Approximately $5 \mathrm{~cm}^{3}$ or $20-30 \mathrm{~cm}^{3}$ of rock powder was transferred into $15 \mathrm{~mL}$ glass Hungate tubes or 100 $\mathrm{mL}$ glass Schott bottles, respectively, and immediately flushed with nitrogen gas to remove oxygen. The glass tubes were sealed with a butyl rubber stopper and filled with sterile (autoclaved and filter sterilized), anoxic $\left(\mathrm{N}_{2}\right.$-sparged) artificial or bottom seawater supplemented with a reducing agent $\left(0.05 \% \mathrm{Na}_{2} \mathrm{~S} \cdot 9 \mathrm{H}_{2} \mathrm{O}\right)$. The Hungate tubes containing rock slurry were placed into high-pressure bottles (Nova Swiss, Switzerland) at 8 to $17 \mathrm{MPa}$ (depending on the depths of the sites) and stored at $4^{\circ} \mathrm{C}$ until processing in the shore-based laboratory. The remaining tubes were stored at $4^{\circ} \mathrm{C}$ at atmospheric pressure $(0.1 \mathrm{MPa})$ until processing in the shore-based laboratory. Enriched and isolated piezophilic microorganisms will then be characterized and compared with other microorganisms enriched and isolated at atmospheric pressure from Atlantis Massif or other deep-sea piezophilic microorganisms isolated from different ecosystems. The targeted metabolic groups will be cultivated in a basal culture medium described below.

For alkaliphilic enrichments, approximately $0.5-1 \mathrm{~cm}^{3}$ of rock sample was used as the inoculum in $5 \mathrm{~mL}$ of anaerobic media $(\mathrm{pH}$ 10) targeting both chemoautotrophic and chemoorganotrophic alkaliphilic microorganisms:

- Hydrogenotrophic methanogens (media overpressured with hydrogen),

- Acetoclastic methanogens (media amended with acetate),

- Methylotrophic methanogens (media amended with methanol),

- Hydrogenotrophic sulfate-reducers (media amended with sulfate and overpressured hydrogen),

- Heterotrophic sulfate-reducers (media amended with acetate), and

- Organic-matter-utilizing microbes (media amended with $2 \mathrm{~g}$ yeast extract and $2 \mathrm{~g}$ tryptone).

The targeted microbial groups were cultivated in a basal culture medium containing (per liter of distilled water):

- $0.3 \mathrm{~g} \mathrm{~K}_{2} \mathrm{HPO}_{4}$,

- $1 \mathrm{~g} \mathrm{NH}_{4} \mathrm{Cl}$,

- $20 \mathrm{~g} \mathrm{NaCl}$,

- $0.1 \mathrm{~g} \mathrm{KCl}$,

- $0.1 \mathrm{~g} \mathrm{CaCl}_{2} \cdot 2 \mathrm{H}_{2} \mathrm{O}$,

- $0.1 \mathrm{~g} \mathrm{MgCl}_{2} \cdot 7 \mathrm{H}_{2} \mathrm{O}$,

- 0.5 g yeast extract,

- $10 \mathrm{~mL}$ of Balch trace elements solution (for methanogens) or 1 $\mathrm{mL}$ of Widdel trace elements solution (for sulfate-reducers),

- $0.5 \mathrm{~g}$ of cysteine hydrochloride (for methanogens),

- $3 \mathrm{~g}$ of Trizma base, and

- $1 \mathrm{~mL}$ of $0.1 \%$ resazurin.

The $\mathrm{pH}$ was adjusted to 10 with $1 \mathrm{M} \mathrm{KOH}$. The medium was boiled under a stream of $\mathrm{O}_{2}$-free $\mathrm{N}_{2}$ gas and cooled to room temperature before being dispensed into Hungate tubes, degassed under $\mathrm{N}_{2}$, and subsequently sterilized by autoclaving at $120^{\circ} \mathrm{C}$ for 45 $\min$.

Prior to inoculation, $0.1 \mathrm{~mL}$ of $2 \%(\mathrm{w} / \mathrm{v}) \mathrm{Na}_{2} \mathrm{~S} \cdot 9 \mathrm{H}_{2} \mathrm{O}, 0.1 \mathrm{~mL}$ of $8 \%(\mathrm{w} / \mathrm{v}) \mathrm{Na}_{2} \mathrm{CO}_{3}$, and different substrates were added into each tubes depending on targeted metabolism:

- $0.1 \mathrm{~mL}$ of $1 \mathrm{M} \mathrm{Na}$-acetate solution,

- $0.1 \mathrm{~mL}$ of $4 \mathrm{M}$ methanol solution,

- $0.1 \mathrm{~mL}$ of $1 \mathrm{M} \mathrm{NaSO}_{4}$ solution, and/or

- $\mathrm{H}_{2}$ from a mixture of $\mathrm{H}_{2} / \mathrm{CO}_{2}(80: 20 \mathrm{v} / \mathrm{v} ; 2$ bar). 
After enrichment for 1 month or more, the enrichments will be checked by microscopy to evaluate growth in the shore-based laboratory. Headspace gas in the enrichments will be analyzed by gas chromatography to evaluate hydrogen production or consumption and $\mathrm{CH}_{4}$ and $\mathrm{H}_{2} \mathrm{~S}$ production, according to methods described in Mei et al. (2014). Enriched samples will be evaluated in the shorebased laboratory using taxonomic (based on 16S rRNA genes) and metagenomic analyses of extracted DNA, following established methods (Quéméneur et al., 2014, 2015). Further enrichment to isolation will be also conducted for comparative genomic analyses to the original samples.

\section{Mineral-associated cultivation}

For cultivating microbial groups associated with mineral attachment, WRC samples were wrapped in sterile Whirl-Pak bags and sealed in gas-impermeable bags with an oxygen scrubber (AnaeroGen, Thermo Scientific) after flushing with $0.22 \mu \mathrm{m}$ mesh-filtered ultrahigh-purity nitrogen gas. Samples will be stored at $4^{\circ} \mathrm{C}$ in this way until the experiment in the onshore laboratory. There, samples will be homogenized under clean air conditions and distributed for incubations following methods described in Suzuki et al. (2014).

\section{Water sampling and sensor package data}

As described in the Expedition 357 Scientific Prospectus (FrühGreen et al., 2015), to achieve the geochemistry and microbiology objectives of the expedition, an extensive water and gas sampling program was included to evaluate the performance of the drills, the composition of fluids emanating from the flushed boreholes, and the possibility for contamination of samples during transit through the water column. In addition to routine sedimentary pore water fluid sampling, this expedition also collected water column fluids using the ship's CTD Niskin bottle rosette and collected bottom water fluids using Niskin bottles mounted on the rock drill sensor packages. Emphasis was also placed on collecting fluid samples for analysis of gas and contamination tracer concentrations. In parallel, a suite of in situ sensors was deployed on the rock drills to quantify dissolved oxygen, methane, temperature, $\mathrm{pH}$, and oxidation-reduction potential (ORP), as outlined in each site chapter. Because this type of water sampling and sensor package program is unique, this section provides more detail on the scope of this program.

\section{In situ sensor package}

An in situ sensor package was developed for this program, based on the industry standard Sea-Bird SBE 55 ECO water sampler. This package (Figure F18A, F18B) consisted of a Sea-Bird SBE 19 plus V2 SeaCAT profiler to measure conductivity, temperature, and pressure. Three additional sensors were mounted on the package: a SBE 63 optical dissolved oxygen sensor, a SBE $27 \mathrm{pH} / \mathrm{ORP}$ (redox) sensor, and a Franatech METS methane sensor. Borehole fluids and cuttings flushed by the drill were pumped through a Tygon tube via a SBE 5T pump and fed past the conductivity, oxygen, and methane sensors, with the exhaust of the pump directed at the $\mathrm{pH} / \mathrm{ORP}$ sensor to bathe it in the same fluids that were flushing through the other sensors. The intake of the Tygon tubing was located approximately $400 \mathrm{~mm}$ above the mouth of the borehole on each rock drill. Given a pumping rate of $100 \mathrm{~mL} / \mathrm{s}$ and a feed tube about $3 \mathrm{~m}$ long and $1.2 \mathrm{~cm}$ in diameter, the delay time to the sensors was less than $4 \mathrm{~s}$.

Because of depth limitations, the $\mathrm{pH} / \mathrm{ORP}$ sensor was removed from deployments at sites deeper than $1200 \mathrm{~m}$ water depth. Upon recovery, sensors were flushed with distilled water to maintain sensor integrity. All sensors were calibrated by the manufacturer prior to delivery to the ship. Because the drill package $\mathrm{pH}$ sensors became our primary source for $\mathrm{pH}$ measurements, they were sent for recalibration at the end of the expedition. Prior to the expedition, the RD2 sensor residual errors were $-0.002,0.004$, and $-0.005 \mathrm{pH}$ units

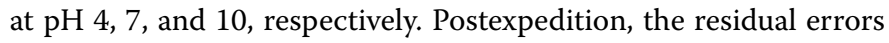
for this sensor were $-0.007,0.015$, and -0.007 at $\mathrm{pH} 4,7$, and 10, respectively. The residual errors for the sensor on MeBo were $-0.012,0.025$, and -0.013 preexpedition and $-0.001,0.002$, and -0.001 postexpedition, again at $\mathrm{pH} 4,7$, and 10 , respectively.

It must be noted that the METS $\mathrm{CH}_{4}$ sensor has some sensitivity to molecular $\mathrm{H}_{2}$, and because we expected significant $\mathrm{H}_{2}$ concentrations in the Atlantis Massif environment, we asked Franatech to evaluate this potentially interfering response level. The results of these tests indicate that the sensor has 0.02 times the sensitivity to $\mathrm{H}_{2}$ as it does to $\mathrm{CH}_{4}$. Thus, when a signal from the METS sensor is described in the site chapters, the signal likely represents a combination of $\mathrm{H}_{2}$ and $\mathrm{CH}_{4}$. Being a membrane device, there is also a delay in the response time of the METS sensor, where a step change in concentration takes on the order of 1-2 min for $90 \%$ response.

During deployments, real-time data streams of the temperature, $\mathrm{pH}$, ORP, and methane sensors were monitored on board the ship using Sea-Bird software, logging the data points versus time. For subsequent data processing, logged sensor files were correlated with drilling logs (i.e., drilling depth versus time), seafloor video footage (i.e., documentation of bubble release during operations), and lithologic information.

\section{Drill-based water sampling package}

A water sampling package with three 4 L Niskin bottles was mounted on each rock drill to sample fluids emanating from the borehole during drilling. The water sampler system (Figure F19) consisted of a modified SBE 55 Electronic Control Module (ECM), SBE 55 lanyard release assembly, three 4 L Niskin bottles, and an additional SBE 5T pump. The Niskin bottles were mounted $0.8 \mathrm{~m}$ above the seafloor on the RD2 rock drill and approximately $1.5 \mathrm{~m}$ above the seafloor on the MeBo drill. Two of the three Niskins were flushed through Tygon tubing with the intake of the tubing placed approximately $400 \mathrm{~mm}$ above the mouth of the borehole. The Tygon tubing was attached to the outlet spigots (left open) of the Niskins, and the top endcaps were left open, allowing the drill fluids to flush through the bottle. The bottom endcaps were left closed with a oneway valve on the inlet system, preventing backflow out of the bottles. With a pumping rate of $100 \mathrm{~mL} / \mathrm{s}$, the turnover time for flushing the bottles was about $1.3 \mathrm{~min}$.

The top endcaps were closed remotely with the SBE 55 ECM, and the pump simultaneously shut off when a water sample was required, trapping the flushed drill fluid in the Niskin bottles. The third bottle was set up in a standard open-ended configuration to sample near-bottom water fluids when triggered. Each bottle could be fired independently via a serial interface to the surface running the SBE Seaterm software, either immediately after completion of drilling or when a peak was seen on the real-time sensor.

The water sampler/sensor package was deployed and recovered in the vertical position on the RD2 drill, whereas the package for the MeBo drill was deployed and recovered in a horizontal position. Thus, if the top endcaps failed to close on RD2 deployments, water samples could still be retained upon recovery, whereupon the top endcaps could be manually closed to preserve dissolved gases. However, failure of the top caps on the MeBo system would result in the 
Figure F18. Seabed drill sensor package, Expedition 357. A. Various sensors mounted on the sensor package and associated wiring. SBE-9pV2 $=$ profiler to measure conductivity, temperature, and pressure. SBE $63=$ optical dissolved oxygen sensor. SBE- $27=\mathrm{pH} / \mathrm{ORP}$ (redox) sensor. METS = methane sensor. SBE-5T = pump. B. Drill-mounted water sensor package sitting behind the Niskin bottles (gray), shown here on the RD2 drill. Left canister = SBE-9pV2 profiler. Middle assembly = Niskin bottle trigger mechanism. Right canister = ECM. The dissolved oxygen, pH/ORP, and methane sensors are located beneath the SBE-9pV2 profiler and are not visible in this image. Image courtesy of Marvin Lilley. (Continued below.)

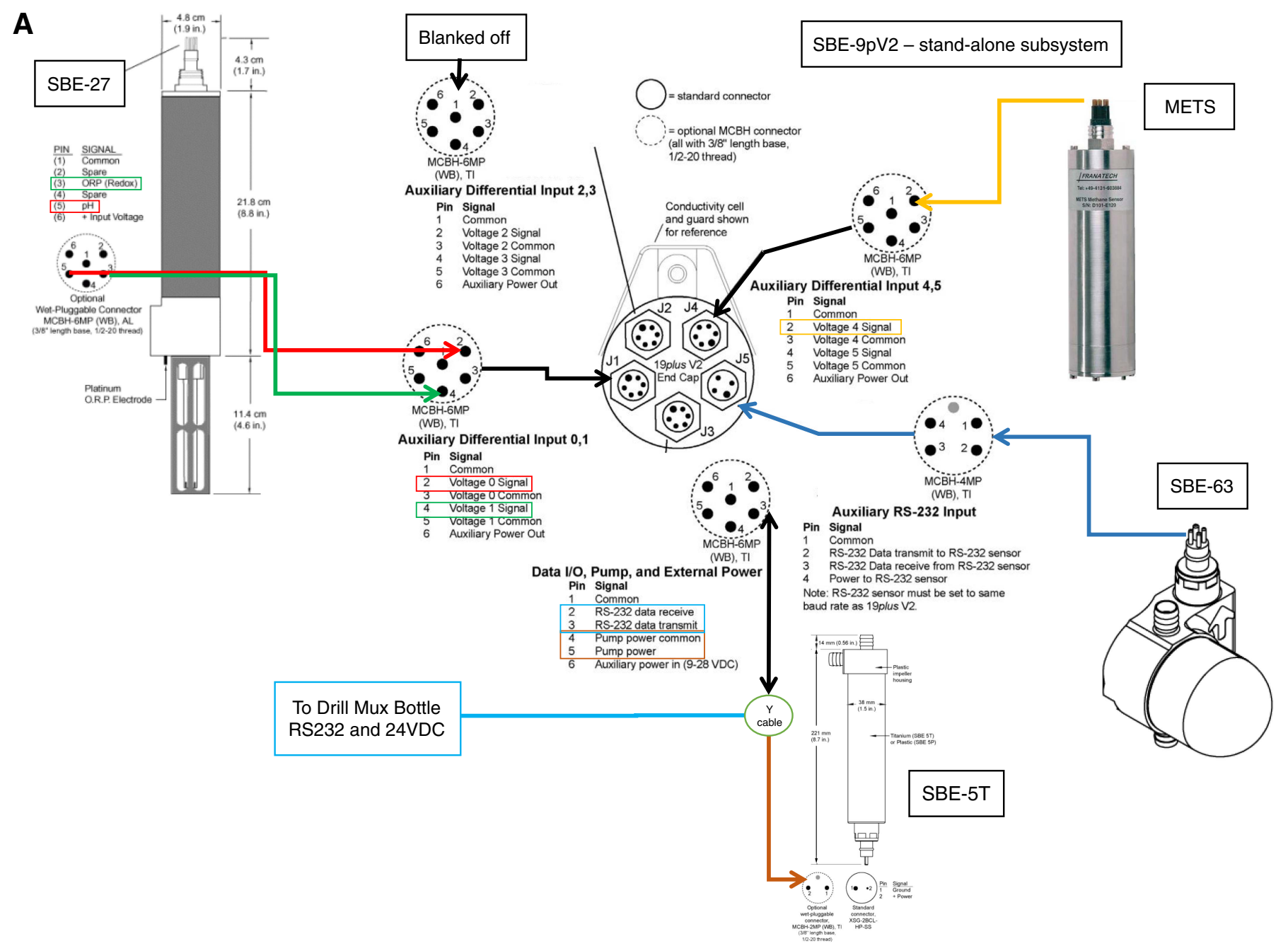

Figure F18 (continued).

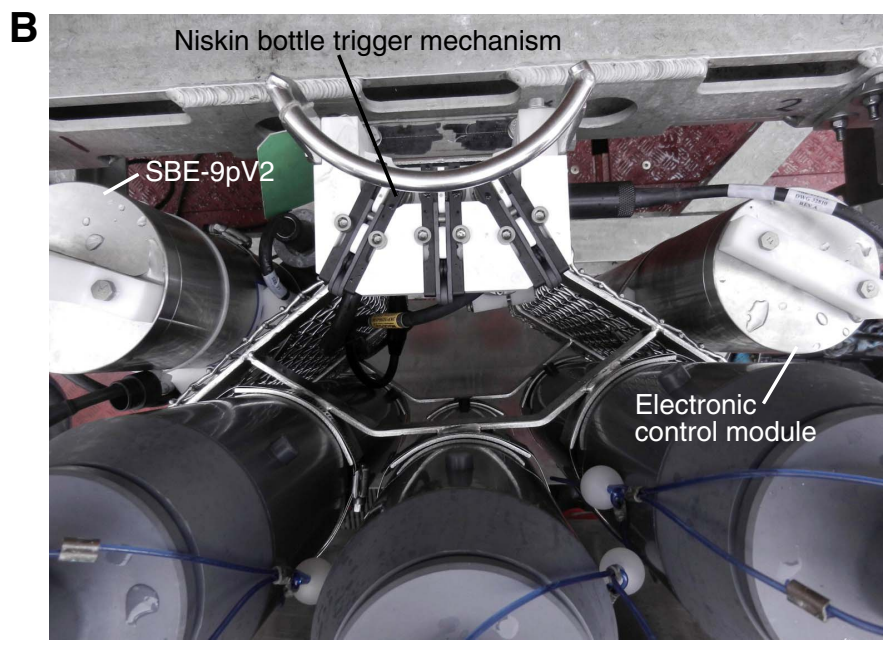

total loss of sample. Additionally, the bottles on the RD2 could be sampled directly on the drill rig, whereas MeBo Niskin bottles were recovered in the horizontal position and required removal from the drill rig prior to sampling. A summary of sensor package/water sampler deployment locations, dates, and sampling times are listed in Table $\mathbf{T} 5$.

\section{Ship's Niskin bottle sampling}

Prior to the deployment of the drill and commencement of drilling operations at each site, a cast of the ship's wireline CTD rosette with six $10 \mathrm{~L}$ Niskin bottles was performed to collect water from as close to the seafloor as possible (generally 2-3 $\mathrm{m}$ above seafloor). These samples were used to characterize the geochemistry and microbiology of the near-basement fluids prior to drilling and for comparison with drill fluids captured with the sensor package sampling. During these casts, three of the $10 \mathrm{~L}$ bottles were triggered near the seafloor. An additional three bottles were triggered at shallower depths in the water column for microbiological characteriza- 
Figure F19. Drill-mounted Niskin bottles, shown here on the RD2 drill, Expedition 357. Image courtesy of Carol Cotterill.

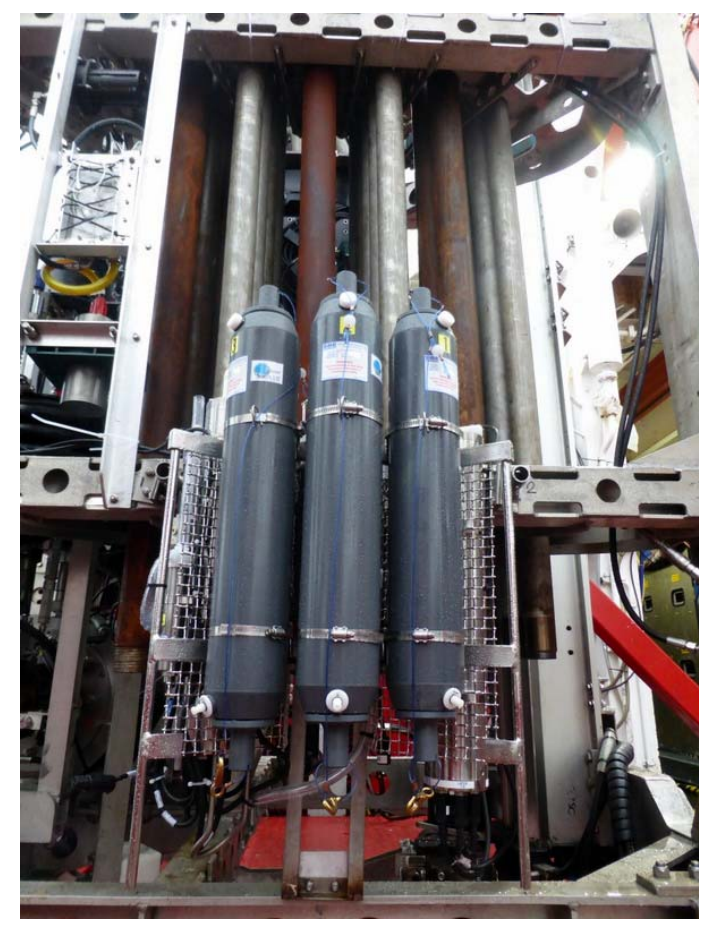

tion to identify seawater microorganisms that the cores may be exposed to during ascension to the surface. In addition to the casts above the sites, two additional casts were conducted away from Atlantis Massif to collect background water and characterize the microbiological and geochemical signatures typical for seawater at these depths. The cast locations, associated drill sites, and trigger depths are listed in Table T6.

\section{Water sample split plan and fixation}

The sampling approach was similar for both the ship's CTD Niskin bottles and the drill rig sensor package Niskin bottles (Table T7). When recovered to deck, samples were immediately collected for $\mathrm{H}_{2}$ and $\mathrm{CH}_{4}$ concentrations and helium isotopes from the rock drill sensor packages. The bottles were subsequently sampled for the PFC tracer, DIC concentrations and isotopes, organic geochemistry, reference samples for sediment interstitial water standard measurements (see below), $\delta \mathrm{D}$ and $\delta^{18} \mathrm{O}$ of water, $\delta^{34} \mathrm{~S}$ of sulfate, cell counts, and nucleic acid extraction. In some cases, water for nongas measurements was first collected into a precleaned 4 low-density polyethylene (LDPE) cubic container and stored at $4{ }^{\circ} \mathrm{C}$ until further processing. On the ship's CTD casts, only the near-bottom Niskin bottles were sampled for geochemistry, and all bottles were sampled for cell counts and nucleic acid extraction. From the rock drill sensor packages, all bottles were sampled for $\mathrm{H}_{2}, \mathrm{CH}_{4}$, PFC tracer concentration, cell counts, and nucleic acids. Only one of the two flushed Niskins was sampled for the remainder of the geochemical analyses.

For $\mathrm{H}_{2}$ and $\mathrm{CH}_{4}$ concentration measurements, $100 \mathrm{~mL}$ of bubble-free water was directly drawn into $140 \mathrm{~mL}$ plastic syringes fitted with two-way stopcocks, followed by the addition of $40 \mathrm{~mL}$ of ultrahigh-purity helium. The sample was vigorously shaken and allowed to warm to room temperature in the analytical laboratory to reach equilibrium. Aliquots of the headspace gas were injected into an SRI
$8610 \mathrm{C}$ gas chromatograph equipped with a $30 \mathrm{~m}$ molecular sieve $5 \mathrm{~A}$ column (Restek MXT-PLOT, $0.53 \mathrm{~mm}$ inner diameter) run at $40^{\circ} \mathrm{C}$ and $18 \mathrm{~mL} / \mathrm{min}$ with ultrapure helium as carrier gas. Make-up helium for the pulsed discharge detector (PDD) was set at $30 \mathrm{~mL} / \mathrm{min}$. $\mathrm{H}_{2}$ concentrations were determined with the PDD, and $\mathrm{CH}_{4}$ concentrations were measured with a flame ionization detector. Gas concentrations were calculated based on $100 \mathrm{ppm}( \pm 5 \%)$ standards of $\mathrm{CH}_{4}$ and $\mathrm{H}_{2}$ in helium (Scotty Analyzed Gases) diluted to 1, 2, 5, and $10 \mathrm{ppm}$ with helium.

For helium isotopes, bubble-free water was collected according to established methods (Young and Lupton, 1983) by flushing fluid through a $1 \mathrm{~m}$ long section of $1.9 \mathrm{~cm}$ diameter refrigeration grade copper tubing and then manually crimping the tubing closed. Samples were stored at room temperature until analysis for concentration and isotope ratios.

Fluids for reference samples for sediment interstitial water standard measurements were collected into $20 \mathrm{~mL}$ plastic syringes and capped until splitting. Samples taken from the ship's CTD Niskin bottles are labeled "IWref1," and samples from the rock drill sensor packages are labeled "IWref2." The fluids were filtered through a 0.2 $\mu \mathrm{m}$ mesh, $25 \mathrm{~mm}$ diameter cellulose acetate filter into a $20 \mathrm{~mL}$ polypropylene vial, and then the samples were distributed for analyses (Table T8).

Samples for organic geochemistry were collected both filtered and unfiltered. Unfiltered fluids were collected directly into both 30 and $125 \mathrm{~mL}$ high-density polyethylene (HDPE) bottles and stored frozen. Filtered samples were first collected into either a precleaned 4 L LDPE cubic container (from the ship's CTD Niskins) or into a precleaned $1 \mathrm{~L}$ HDPE bottle (from the rock drill sensor packages). The water was filtered through two precombusted $\left(500^{\circ} \mathrm{C}\right.$ for $\left.5 \mathrm{~h}\right)$ GF/75 $47 \mathrm{~mm}$ filters ( $0.3 \mu \mathrm{m}$ nominal pore size, Advantec) using a peristaltic pump and silicon tubing. The two filters were stacked on top of each other. The upper filter was used for particulate organic matter concentration and isotope analysis, and the bottom one was used to assess the amount of dissolved organic carbon (DOC) sorbed to the glass fiber during filtering. The filtrate was collected into 30 and $125 \mathrm{~mL}$ HDPE bottles that were stored frozen. All bottles, tubing, and filter holders were acid washed ( $5 \% \mathrm{HCl}$; overnight) prior to use. Both filtered and unfiltered samples will be analyzed for DOC concentrations and amino acid concentrations according to established methods (Cowie and Hedges, 1992a).

Water samples were collected from the rock drill sensor package Niskins into $1 \mathrm{~L}$ HDPE bottles for analysis of the ${ }^{14} \mathrm{C}$ content of DOC by the National Ocean Sciences Accelerator Mass Spectrometry Facility (NOSAMS) following established protocols (Beaupré et al., 2007). On one of background ship's CTD casts, additional samples for analysis of the ${ }^{14} \mathrm{C}$ content of DIC were collected. Bubblefree water from the Niskin bottle was transferred with Tygon tubing to the bottom of a $250 \mathrm{~mL}$ Pyrex bottle with a ground-glass stopper. Water was allowed to flush for 1.5 bottle volumes before the bottle was closed. In the laboratory, $10 \mathrm{~mL}$ of the fluid was drawn off with a syringe, and the samples were poisoned with $100 \mu \mathrm{L}$ of saturated mercuric chloride. Apiezon grease was applied to the ground glass stopper, and the bottle was closed and stored in the dark at room temperature.

To enable ${ }^{14} \mathrm{C}$ measurements, extensive surveys of the ship's laboratories and equipment were conducted prior to the expedition to assess for potential tracer ${ }^{14} \mathrm{C}$ contamination. Tests for gross contamination were collected according to the protocols of Project SWAB at the University of Miami (http://www.rsmas.miami.edu/groups/tritium/swab). In brief, the detergent Count-Off 
Table T5. Sensor package (SP) Niskin bottles sampled for fluid chemistry, gas chemistry, and microbiology, Expedition 357. RD2 Niskins 1 and 2 were connected to tubing and fed water via a pump from close to the breakout table; Niskin 3 was not connected to tubing and was situated approximately $0.8 \mathrm{~m}$ above the seafloor. MeBo Niskins 2 and 3 were connected to the tubing and pump; Niskin 1 was not connected and was situated approximately $1.5 \mathrm{~m}$ above the seafloor. Start and end dates refer to drill deployment and recovery. Niskin trigger times are when the bottles on the sensor package were fired. Times are local (GMT $2 \mathrm{~h}$ ). $\mathrm{COD}=$ closed on deck; bottles triggered but did not fire; water remained in the two Niskins connected to the pump; Niskins were capped $\sim 40$ min after arrival on deck (Hole M0069A) or immediately upon arrival on deck (Hole M0070B). DNF = did not fire; bottles triggered but did not fire. Download table in .csv format.

\begin{tabular}{|c|c|c|c|c|c|c|c|c|}
\hline $\begin{array}{l}\text { Drill } \\
\text { hole }\end{array}$ & $\begin{array}{l}\text { Rock } \\
\text { drill }\end{array}$ & Device & $\begin{array}{c}\text { Site } \\
\text { depth (m) }\end{array}$ & $\begin{array}{l}\text { Start date } \\
\text { (2015) }\end{array}$ & $\begin{array}{l}\text { End date } \\
(2015)\end{array}$ & $\begin{array}{l}\text { Niskin } \\
\text { trigger time } \\
\text { (h UTC) }\end{array}$ & Latitude & Longitude \\
\hline M0068A & RD2 & SP Niskin 1, pumped & 1102.7 & $6 \mathrm{Nov}$ & 6 Nov & 0800 & $30^{\circ} 7.49^{\prime} \mathrm{N}$ & $42^{\circ} 5.74^{\prime} \mathrm{W}$ \\
\hline M0068A & RD2 & SP Niskin 2, pumped & 1102.7 & $6 \mathrm{Nov}$ & $6 \mathrm{Nov}$ & 0800 & $30^{\circ} 7.49^{\prime} \mathrm{N}$ & $42^{\circ} 5.74^{\prime} \mathrm{W}$ \\
\hline M0068B & $\mathrm{RD} 2$ & SP Niskin 1, pumped & 1102.0 & $23 \mathrm{Nov}$ & $25 \mathrm{Nov}$ & 0903 & $30^{\circ} 7.51^{\prime} \mathrm{N}$ & $42^{\circ} 5.75^{\prime} \mathrm{W}$ \\
\hline M0068B & RD2 & SP Niskin 2, pumped & 1102.0 & $23 \mathrm{Nov}$ & $25 \mathrm{Nov}$ & 0902 & $30^{\circ} 7.51^{\prime} \mathrm{N}$ & $42^{\circ} 5.75^{\prime} \mathrm{W}$ \\
\hline M0068B & $\mathrm{RD} 2$ & SP Niskin 3, not pumped & 1102.0 & $23 \mathrm{Nov}$ & $25 \mathrm{Nov}$ & 0903 & $30^{\circ} 7.51^{\prime} \mathrm{N}$ & $42^{\circ} 5.75^{\prime} \mathrm{W}$ \\
\hline M0069A & $\mathrm{RD} 2$ & SP Niskin 1, pumped & 850.9 & $6 \mathrm{Nov}$ & $8 \mathrm{Nov}$ & COD & $30^{\circ} 7.94^{\prime} \mathrm{N}$ & $42^{\circ} 7.20^{\prime} \mathrm{W}$ \\
\hline M0069A & $\mathrm{RD} 2$ & SP Niskin 2, pumped & 850.9 & $6 \mathrm{Nov}$ & $8 \mathrm{Nov}$ & COD & $30^{\circ} 7.94^{\prime} \mathrm{N}$ & $42^{\circ} 7.20^{\prime} \mathrm{W}$ \\
\hline M0070A & MeBo & SP Niskin 1, not pumped & 1140.5 & $8 \mathrm{Nov}$ & 9 Nov & 0245 & $30^{\circ} 8.55^{\prime} \mathrm{N}$ & $42^{\circ} 8.19^{\prime} \mathrm{W}$ \\
\hline M0070A & MeBo & SP Niskin 2, pumped & 1140.5 & $8 \mathrm{Nov}$ & 9 Nov & 0245 & $30^{\circ} 8.55^{\prime} \mathrm{N}$ & $42^{\circ} 8.19^{\prime} \mathrm{W}$ \\
\hline M0070A & MeBo & SP Niskin 3, pumped & 1140.5 & $8 \mathrm{Nov}$ & 9 Nov & 0245 & $30^{\circ} 8.55^{\prime} \mathrm{N}$ & $42^{\circ} 8.19^{\prime} \mathrm{W}$ \\
\hline М0070B & $\mathrm{RD} 2$ & SP Niskin 1, pumped & 1140.5 & $14 \mathrm{Nov}$ & $14 \mathrm{Nov}$ & COD & $30^{\circ} 8.54^{\prime} \mathrm{N}$ & $42^{\circ} 8.16^{\prime} W$ \\
\hline M0070B & $\mathrm{RD} 2$ & SP Niskin 2, pumped & & & $14 \mathrm{Nov}$ & COD & $30^{\circ} 8.54^{\prime} \mathrm{N}$ & $42^{\circ} 8.16^{\prime} \mathrm{W}$ \\
\hline M0071A & MeBo & SP Niskin 1, not pumped & 1390.8 & $9 \mathrm{Nov}$ & $10 \mathrm{Nov}$ & 0245 & $30^{\circ} 7.71^{\prime} \mathrm{N}$ & $42^{\circ} 9.20^{\prime} \mathrm{W}$ \\
\hline M0071A & MeBo & SP Niskin 2, pumped & 1390.8 & $9 \mathrm{Nov}$ & $10 \mathrm{Nov}$ & 0245 & $30^{\circ} 7.71^{\prime} \mathrm{N}$ & $42^{\circ} 9.20^{\prime} \mathrm{W}$ \\
\hline M0071A & MeBo & SP Niskin 3, pumped & 1390.8 & $9 \mathrm{Nov}$ & $10 \mathrm{Nov}$ & 0245 & $30^{\circ} 7.71^{\prime} \mathrm{N}$ & $42^{\circ} 9.20^{\prime} \mathrm{W}$ \\
\hline M0071B & RD2 & SP Niskin 1, pumped & 1390.8 & $18 \mathrm{Nov}$ & $19 \mathrm{Nov}$ & 0841 & $30^{\circ} 7.72^{\prime} \mathrm{N}$ & $42^{\circ} 9.19^{\prime} \mathrm{W}$ \\
\hline M0071B & RD2 & SP Niskin 2, pumped & 1390.8 & $18 \mathrm{Nov}$ & $19 \mathrm{Nov}$ & 0816 & $30^{\circ} 7.72^{\prime} \mathrm{N}$ & $42^{\circ} 9.19^{\prime} \mathrm{W}$ \\
\hline M0071B & RD2 & SP Niskin 3, not pumped & 1390.8 & $18 \mathrm{Nov}$ & $19 \mathrm{Nov}$ & 0841 & $30^{\circ} 7.72^{\prime} \mathrm{N}$ & $42^{\circ} 9.19^{\prime} \mathrm{W}$ \\
\hline M0071C & MeBo & SP Niskin 1, not pumped & 1390.0 & $25 \mathrm{Nov}$ & $28 \mathrm{Nov}$ & 0050 & $30^{\circ} 7.70^{\prime} \mathrm{N}$ & $42^{\circ} 9.21^{\prime} \mathrm{W}$ \\
\hline M0071C & MeBo & SP Niskin 2, pumped & 1390.0 & $25 \mathrm{Nov}$ & $28 \mathrm{Nov}$ & 0050 & $30^{\circ} 7.70^{\prime} \mathrm{N}$ & $42^{\circ} 9.21^{\prime} \mathrm{W}$ \\
\hline M0071C & MeBo & SP Niskin 3, pumped & 1390.0 & $25 \mathrm{Nov}$ & $28 \mathrm{Nov}$ & 0050 & $30^{\circ} 7.70^{\prime} \mathrm{N}$ & $42^{\circ} 9.21^{\prime} \mathrm{W}$ \\
\hline M0072A & RD2 & SP Niskin 1, pumped & 820.3 & $10 \mathrm{Nov}$ & $10 \mathrm{Nov}$ & 1503 & $30^{\circ} 7.79^{\prime} \mathrm{N}$ & $42^{\circ} 7.32^{\prime} \mathrm{W}$ \\
\hline M0072A & RD2 & SP Niskin 2, pumped & 820.3 & $10 \mathrm{Nov}$ & $10 \mathrm{Nov}$ & 1501 & $30^{\circ} 7.79^{\prime} \mathrm{N}$ & $42^{\circ} 7.32^{\prime} \mathrm{W}$ \\
\hline M0072A & $\mathrm{RD} 2$ & SP Niskin 3, not pumped & 820.3 & $10 \mathrm{Nov}$ & $10 \mathrm{Nov}$ & 1503 & $30^{\circ} 7.79^{\prime} \mathrm{N}$ & $42^{\circ} 7.32^{\prime} \mathrm{W}$ \\
\hline M0072B & RD2 & SP Niskin 1, pumped & 820.3 & $10 \mathrm{Nov}$ & $12 \mathrm{Nov}$ & 0625 & $30^{\circ} 7.79^{\prime} \mathrm{N}$ & $42^{\circ} 7.32^{\prime} \mathrm{W}$ \\
\hline M0072B & RD2 & SP Niskin 2, pumped & 820.3 & $10 \mathrm{Nov}$ & $12 \mathrm{Nov}$ & 0625 & $30^{\circ} 7.79^{\prime} \mathrm{N}$ & $42^{\circ} 7.32^{\prime} \mathrm{W}$ \\
\hline M0072B & RD2 & SP Niskin 3, not pumped & 820.3 & $10 \mathrm{Nov}$ & $12 \mathrm{Nov}$ & 0625 & $30^{\circ} 7.79^{\prime} \mathrm{N}$ & $42^{\circ} 7.32^{\prime} \mathrm{W}$ \\
\hline M0073A & MeBo & SP Niskin 1, not pumped & 1430.2 & $15 \mathrm{Nov}$ & $15 \mathrm{Nov}$ & 0630 & $30^{\circ} 7.90^{\prime} \mathrm{N}$ & $42^{\circ} 10.97^{\prime} \mathrm{W}$ \\
\hline M0074A & MeBo & SP Niskin 1, not pumped & 1550.0 & $30 \mathrm{Nov}$ & $30 \mathrm{Nov}$ & 1328 & $30^{\circ} 9.87^{\prime} \mathrm{N}$ & $42^{\circ} 7.32^{\prime} \mathrm{W}$ \\
\hline M0075A & MeBo & No water collected & 1585.6 & $14 \mathrm{Nov}$ & $14 \mathrm{Nov}$ & DNF & $30^{\circ} 7.66^{\prime} \mathrm{N}$ & $42^{\circ} 3.91^{\prime} \mathrm{W}$ \\
\hline M0075A & $\mathrm{RD} 2$ & SP Niskin 1, pumped & 1568.0 & $28 \mathrm{Nov}$ & $29 \mathrm{Nov}$ & 1407 & $30^{\circ} 7.67^{\prime} \mathrm{N}$ & $42^{\circ} 3.98^{\prime} \mathrm{W}$ \\
\hline M0075A & RD2 & SP Niskin 2, pumped & 1568.0 & $28 \mathrm{Nov}$ & $29 \mathrm{Nov}$ & 1406 & $30^{\circ} 7.67^{\prime} \mathrm{N}$ & $42^{\circ} 3.98^{\prime} \mathrm{W}$ \\
\hline M0075A & RD2 & SP Niskin 3, not pumped & 1568.0 & $28 \mathrm{Nov}$ & $29 \mathrm{Nov}$ & 1406 & $30^{\circ} 7.67^{\prime} \mathrm{N}$ & $42^{\circ} 3.98^{\prime} \mathrm{W}$ \\
\hline M0075B & MeBo & SP Niskin 1, not pumped & 1568.0 & $29 \mathrm{Nov}$ & $30 \mathrm{Nov}$ & 0615 & $30^{\circ} 7.65^{\prime} \mathrm{N}$ & $42^{\circ} 3.97^{\prime} \mathrm{W}$ \\
\hline M0075B & MeBo & SP Niskin 2, pumped & 1568.0 & $29 \mathrm{Nov}$ & $30 \mathrm{Nov}$ & 0614 & $30^{\circ} 7.65^{\prime} \mathrm{N}$ & $42^{\circ} 3.97^{\prime} \mathrm{W}$ \\
\hline M0075B & MeBo & SP Niskin 3, pumped & 1568.0 & $29 \mathrm{Nov}$ & $30 \mathrm{Nov}$ & 0614 & $30^{\circ} 7.65^{\prime} \mathrm{N}$ & $42^{\circ} 3.97^{\prime} \mathrm{W}$ \\
\hline M0076A & $\mathrm{RD} 2$ & No water collected & 768.0 & $15 \mathrm{Nov}$ & $15 \mathrm{Nov}$ & DNF & $30^{\circ} 7.62^{\prime} \mathrm{N}$ & $42^{\circ} 7.08^{\prime} \mathrm{W}$ \\
\hline M0076B & $\mathrm{RD} 2$ & SP Niskin 1, pumped & 768.0 & $15 \mathrm{Nov}$ & $17 \mathrm{Nov}$ & 1531 & $30^{\circ} 7.62^{\prime} \mathrm{N}$ & $42^{\circ} 7.07^{\prime} \mathrm{W}$ \\
\hline M0076B & RD2 & SP Niskin 2, pumped & 768.0 & $15 \mathrm{Nov}$ & $17 \mathrm{Nov}$ & 1243 & $30^{\circ} 7.62^{\prime} \mathrm{N}$ & $42^{\circ} 7.07^{\prime} \mathrm{W}$ \\
\hline M0076B & RD2 & SP Niskin 3, not pumped & 768.0 & $15 \mathrm{Nov}$ & $17 \mathrm{Nov}$ & 1531 & $30^{\circ} 7.62^{\prime} \mathrm{N}$ & $42^{\circ} 7.07^{\prime} \mathrm{W}$ \\
\hline
\end{tabular}

was spread on test patches and then transferred to bottles using one-time-use disposable sponges. Samples were submitted to the Tritium Laboratory at the University of Miami (Florida, USA) and analyzed by scintillation counting. More sensitive swipe testing for contamination that could still be problematic for natural abundance ${ }^{14} \mathrm{C}$ analysis was performed in the same locations by wetting a precombusted $\left(500^{\circ} \mathrm{C} ; 5 \mathrm{~h}\right)$ quartz filter with methanol and then wiping test surfaces. The filters were rolled into 2-dram screw-cap vials and shipped to NOSAMS for analysis. Two fume hoods were identified as having postmodern ${ }^{14} \mathrm{C}$ levels. All fume hoods were therefore thoroughly cleaned with dilute acid $(4 \% \mathrm{HCl})$, Contrad 70 detergent (Decon Labs P/N 1002), and Milli-Q (18 M 2 ) water. Teflon sheeting was then placed on top of all fume hood surfaces. No organic geochemical samples or ${ }^{14} \mathrm{C}$ samples were exposed in these fume hoods, and no other tested areas were identified as problematic, including sample processing equipment such as mortar and pestles, rock saws, and rock boxes and surfaces such as laboratory benches. As an additional precaution, Teflon sheeting was affixed on laboratory benches used for organic geochemistry sample processing. Sample bottles for DOC and DIC ${ }^{14} \mathrm{C}$ analysis were placed in indi- 
Table T6. CTD rosette cast locations, depths, and associated drill holes, Expedition 357. Download table in .csv format.

\begin{tabular}{|c|c|c|c|c|c|c|c|c|}
\hline Cast $N$ & Hole & Bottle N & $\begin{array}{c}\text { Site } \\
\text { depth }(m)\end{array}$ & $\begin{array}{l}\text { Date } \\
\text { (2015) }\end{array}$ & Latitude & Longitude & $\begin{array}{c}\text { Sample } \\
\text { depth }(m)\end{array}$ & $\begin{array}{l}\text { Altimeter } \\
(\mathrm{m})\end{array}$ \\
\hline JC130_001 & M0068A & $1,5,9$ & 1001 & $6 \mathrm{Nov}$ & $30^{\circ} 7.51^{\prime} \mathrm{N}$ & $42^{\circ} 5.75^{\prime} \mathrm{W}$ & 1099 & 2.2 \\
\hline JC130_001 & M0068A & 13 & 1001 & $6 \mathrm{Nov}$ & $30^{\circ} 7.95^{\prime} \mathrm{N}$ & $42^{\circ} 5.75^{\prime} \mathrm{W}$ & 763 & \\
\hline JC130_001 & M0068A & 17 & 1001 & $6 \mathrm{Nov}$ & $30^{\circ} 7.95^{\prime} \mathrm{N}$ & $42^{\circ} 5.75^{\prime} \mathrm{W}$ & 385 & \\
\hline JC130_001 & M0068A & 21 & 1001 & $6 \mathrm{Nov}$ & $30^{\circ} 7.95^{\prime} \mathrm{N}$ & $42^{\circ} 5.75^{\prime} \mathrm{W}$ & 8 & \\
\hline JC130_002 & M0069A & $1,5,9$ & 849 & $6 \mathrm{Nov}$ & $30^{\circ} 7.98^{\prime} \mathrm{N}$ & $42^{\circ} 7.22^{\prime} \mathrm{W}$ & 848 & $1.7-3.0$ \\
\hline JC130_002 & M0069A & 13 & 849 & $6 \mathrm{Nov}$ & $30^{\circ} 7.98^{\prime} \mathrm{N}$ & $42^{\circ} 7.22^{\prime} \mathrm{W}$ & 583 & \\
\hline JC130_002 & M0069A & 17 & 849 & $6 \mathrm{Nov}$ & $30^{\circ} 7.98^{\prime} \mathrm{N}$ & $42^{\circ} 7.22^{\prime} \mathrm{W}$ & 293 & \\
\hline JC130_002 & M0069A & 21 & 849 & 6 Nov & $30^{\circ} 7.98^{\prime} \mathrm{N}$ & $42^{\circ} 7.22^{\prime} \mathrm{W}$ & 11 & \\
\hline JC130_003 & M0069A & 1 & 851 & 8 Nov & $30^{\circ} 7.95^{\prime} \mathrm{N}$ & $42^{\circ} 7.20^{\prime} \mathrm{W}$ & 848 & $2.1-2.7$ \\
\hline JC130_003 & M0069A & 9 & 851 & $8 \mathrm{Nov}$ & $30^{\circ} 7.95^{\prime} \mathrm{N}$ & $42^{\circ} 7.20^{\prime} \mathrm{W}$ & 848 & $2.1-2.7$ \\
\hline JC130_003 & M0069A & 13 & 851 & $8 \mathrm{Nov}$ & $30^{\circ} 7.95^{\prime} \mathrm{N}$ & $42^{\circ} 7.20^{\prime} \mathrm{W}$ & 848 & $2.1-2.7$ \\
\hline JC130_004 & M0070A & $1,5,9$ & 1140 & $8 \mathrm{Nov}$ & $30^{\circ} 8.54^{\prime} \mathrm{N}$ & $42^{\circ} 8.20^{\prime} \mathrm{W}$ & 1138 & 1.7 \\
\hline JC130_004 & M0070A & 13 & 1140 & $8 \mathrm{Nov}$ & $30^{\circ} 8.54^{\prime} \mathrm{N}$ & $42^{\circ} 8.20^{\prime} \mathrm{W}$ & 760 & \\
\hline JC130_004 & M0070A & 17 & 1140 & $8 \mathrm{Nov}$ & $30^{\circ} 8.54^{\prime} \mathrm{N}$ & $42^{\circ} 8.20^{\prime} \mathrm{W}$ & 380 & \\
\hline JC130_004 & M0070A & 21 & 1140 & $8 \mathrm{Nov}$ & $30^{\circ} 8.54^{\prime} \mathrm{N}$ & $42^{\circ} 8.20^{\prime} \mathrm{W}$ & 5 & \\
\hline JC130_005 & M0071A & $1,5,9$ & 1384 & 9 Nov & $30^{\circ} 7.69^{\prime} \mathrm{N}$ & $42^{\circ} 9.21^{\prime} \mathrm{W}$ & 1387 & 2.2 \\
\hline JC130_005 & M0071A & 13 & 1384 & $9 \mathrm{Nov}$ & $30^{\circ} 7.69^{\prime} \mathrm{N}$ & $42^{\circ} 9.21^{\prime} \mathrm{W}$ & 902 & \\
\hline JC130_005 & M0071A & 17 & 1384 & 9 Nov & $30^{\circ} 7.69^{\prime} \mathrm{N}$ & $42^{\circ} 9.21^{\prime} \mathrm{W}$ & 454 & \\
\hline JC130_005 & M0071A & 21 & 1384 & $9 \mathrm{Nov}$ & $30^{\circ} 7.69^{\prime} \mathrm{N}$ & $42^{\circ} 9.21^{\prime} \mathrm{W}$ & 6 & \\
\hline JC130_006 & M0072A & $1,5,9$ & 826 & $10 \mathrm{Nov}$ & $30^{\circ} 7.79^{\prime} \mathrm{N}$ & $42^{\circ} 7.34^{\prime} \mathrm{W}$ & 818 & $1.8-2.3$ \\
\hline JC130_006 & M0072A & 13 & 826 & $10 \mathrm{Nov}$ & $30^{\circ} 7.79^{\prime} \mathrm{N}$ & $42^{\circ} 7.34^{\prime} \mathrm{W}$ & 482 & \\
\hline JC130_006 & M0072A & 17 & 826 & $10 \mathrm{Nov}$ & $30^{\circ} 7.79^{\prime} \mathrm{N}$ & $42^{\circ} 7.34^{\prime} \mathrm{W}$ & 243 & \\
\hline JC130_006 & M0072A & 21 & 826 & $10 \mathrm{Nov}$ & $30^{\circ} 7.79^{\prime} \mathrm{N}$ & $42^{\circ} 7.34^{\prime} \mathrm{W}$ & 4 & \\
\hline JC130_007 & M0072X & 1 & 4244 & $11 \mathrm{Nov}$ & $30^{\circ} 2.01^{\prime} \mathrm{N}$ & $42^{\circ} 6.94^{\prime} \mathrm{W}$ & 4134 & \\
\hline JC130_007 & M0072X & 5 & 4244 & $11 \mathrm{Nov}$ & $30^{\circ} 2.01^{\prime} \mathrm{N}$ & $42^{\circ} 6.94^{\prime} \mathrm{W}$ & 4135 & \\
\hline JC130_007 & M0072X & 9 & 4244 & $11 \mathrm{Nov}$ & $30^{\circ} 2.01^{\prime} \mathrm{N}$ & $42^{\circ} 6.94^{\prime} \mathrm{W}$ & 1601 & \\
\hline JC130_007 & M0072X & 17 & 4244 & $11 \mathrm{Nov}$ & $30^{\circ} 2.01^{\prime} \mathrm{N}$ & $42^{\circ} 6.94^{\prime} \mathrm{W}$ & 755 & \\
\hline JC130_008 & M0073A & $1,5,9$ & 1432 & $12 \mathrm{Nov}$ & $30^{\circ} 7.87^{\prime} \mathrm{N}$ & $42^{\circ} 10.95^{\prime} \mathrm{W}$ & 1428 & $1.5-1.8$ \\
\hline JC130_008 & M0073A & 13 & 1432 & $12 \mathrm{Nov}$ & $30^{\circ} 7.87^{\prime} \mathrm{N}$ & $42^{\circ} 10.95^{\prime} \mathrm{W}$ & 960 & \\
\hline JC130_008 & M0073A & 17 & 1432 & $12 \mathrm{Nov}$ & $30^{\circ} 7.87^{\prime} \mathrm{N}$ & $42^{\circ} 10.95^{\prime} \mathrm{W}$ & 482 & \\
\hline JC130_008 & M0073A & 21 & 1432 & $12 \mathrm{Nov}$ & $30^{\circ} 7.87^{\prime} \mathrm{N}$ & $42^{\circ} 10.95^{\prime} W$ & 4 & \\
\hline JC130_009 & M0074A & 1,5 & 1550 & $13 \mathrm{Nov}$ & $30^{\circ} 09.85^{\prime} \mathrm{N}$ & $42^{\circ} 07.29^{\prime} \mathrm{W}$ & 1550 & 1.3 \\
\hline JC130_009 & M0074A & 9 & 1550 & $13 \mathrm{Nov}$ & $30^{\circ} 09.85^{\prime} \mathrm{N}$ & $42^{\circ} 07.29^{\prime} \mathrm{W}$ & 1041 & \\
\hline JC130_009 & M0074A & 13 & 1550 & $13 \mathrm{Nov}$ & $30^{\circ} 09.85^{\prime} \mathrm{N}$ & $42^{\circ} 07.29^{\prime} \mathrm{W}$ & 752 & \\
\hline JC130_009 & M0074A & 17 & 1550 & $13 \mathrm{Nov}$ & $30^{\circ} 09.85^{\prime} \mathrm{N}$ & $42^{\circ} 07.29^{\prime} \mathrm{W}$ & 523 & \\
\hline JC130_009 & M0074A & 21 & 1550 & $13 \mathrm{Nov}$ & $30^{\circ} 09.85^{\prime} \mathrm{N}$ & $42^{\circ} 07.29^{\prime} \mathrm{W}$ & 6 & \\
\hline JC130_010 & M0075A & $1,5,9$ & 1572 & $14 \mathrm{Nov}$ & $30^{\circ} 7.67^{\prime} \mathrm{N}$ & $42^{\circ} 3.91^{\prime} \mathrm{W}$ & 1581 & $2.3-4.5$ \\
\hline JC130_010 & M0075A & 13 & 1572 & $14 \mathrm{Nov}$ & $30^{\circ} 7.67^{\prime} \mathrm{N}$ & $42^{\circ} 3.91^{\prime} \mathrm{W}$ & 1061 & \\
\hline JC130_010 & M0075A & 17 & 1572 & $14 \mathrm{Nov}$ & $30^{\circ} 7.67^{\prime} \mathrm{N}$ & $42^{\circ} 3.91^{\prime} \mathrm{W}$ & 534 & \\
\hline JC130_010 & M0075A & 21 & 1572 & $14 \mathrm{Nov}$ & $30^{\circ} 7.67^{\prime} \mathrm{N}$ & $42^{\circ} 3.91^{\prime} \mathrm{W}$ & 7 & \\
\hline JC130_11 & M0075X & 1,5 & 4217 & $14 \mathrm{Nov}$ & $30^{\circ} 6.49^{\prime} \mathrm{N}$ & $41^{\circ} 59.87^{\prime} \mathrm{W}$ & 4221 & 2.0 \\
\hline JC130_11 & M0075X & 9,13 & 4217 & $14 \mathrm{Nov}$ & $30^{\circ} 6.49^{\prime} \mathrm{N}$ & $41^{\circ} 59.87^{\prime} \mathrm{W}$ & 4124 & \\
\hline JC130_11 & M0075X & 17,21 & 4217 & $14 \mathrm{Nov}$ & $30^{\circ} 6.49^{\prime} \mathrm{N}$ & $41^{\circ} 59.87^{\prime} \mathrm{W}$ & 4023 & \\
\hline JC130_12 & M0075Z & 1,5 & 821 & $1 \mathrm{Dec}$ & $30^{\circ} 7.44^{\prime} \mathrm{N}$ & $42^{\circ} 7.16^{\prime} \mathrm{W}$ & 807 & \\
\hline JC130_12 & M0075Z & 9,13 & 821 & $1 \mathrm{Dec}$ & $30^{\circ} 7.44^{\prime} \mathrm{N}$ & $42^{\circ} 7.16^{\prime} \mathrm{W}$ & 802 & \\
\hline JC130_12 & M0075Z & 17,21 & 821 & $1 \mathrm{Dec}$ & $30^{\circ} 7.44^{\prime} \mathrm{N}$ & $42^{\circ} 7.16^{\prime} \mathrm{W}$ & 797 & \\
\hline
\end{tabular}

vidual bags prior to arriving on the ship; the bags will be removed prior to shipping samples to NOSAMS for analysis.

Fluid samples for $\delta \mathrm{D}$ and $\delta^{18} \mathrm{O}$ of water and $\delta^{34} \mathrm{~S}$ of sulfate were collected from the filtrate of the GF/75 filters used to collect organic carbon samples (from the ship's CTD Niskins) or from the Sterivex filters used to collect nucleic acid samples (from the rock drill sensor package Niskins, as described below). Aliquots of $60 \mathrm{~mL}$ were collected into amber HDPE bottles and stored at room temperature. Samples for sulfur isotopes were acidified to $\mathrm{pH} 3$ with $30 \% \mathrm{HCl}$.

Samples for cell detection and enumeration were collected into sterile $50 \mathrm{~mL}$ plastic centrifuge tubes and stored at $4^{\circ} \mathrm{C}$ until processing. In some cases, cells were fixed by adding formaldehyde at
$2 \%-4 \%$ concentration and storing at $4^{\circ} \mathrm{C}$ until analysis in a shorebased laboratory. In other cases, samples were frozen directly in a CAS freezer.

To assess microbial community composition in water samples, fluids for nucleic acid extraction were collected into precleaned $4 \mathrm{~L}$ cubic containers and stored at $4^{\circ} \mathrm{C}$ until further processing. Fluids were subsequently filtered onto $0.22 \mu \mathrm{m}$ mesh Sterivex filter cartridges (Millipore, Billerica, Massachusetts, USA) using an inline peristaltic pump; 1-4 L of fluid was filtered in duplicate per sample. Sterivex filter cartridges were stored frozen at $-80^{\circ} \mathrm{C}$ until analysis in a shore-based laboratory following previously described methods (Brazelton et al., 2013). 
Table T7. Sampling scheme for Niskin bottles from typical ship's CTD rosette casts and rock drill sensor packages, Expedition 357. Download table in .csv format.

\begin{tabular}{|c|c|c|c|c|c|c|c|c|c|c|}
\hline Sample type & $\begin{array}{l}\text { CTD bottom } \\
\text { water }\end{array}$ & $\begin{array}{l}\text { CTD lower } \\
\text { midwater }\end{array}$ & $\begin{array}{l}\text { CTD upper } \\
\text { midwater }\end{array}$ & $\begin{array}{l}\text { CTD } \\
\text { surface }\end{array}$ & $\begin{array}{l}\text { RD2 Niskin } \\
\text { bottle } 1 \\
\text { (pumped) }\end{array}$ & $\begin{array}{l}\text { RD2 Niskin } \\
\text { bottle } 2 \\
\text { (pumped) }\end{array}$ & $\begin{array}{l}\text { RD2 Niskin } \\
\text { bottle } 3 \\
\text { (free) }\end{array}$ & $\begin{array}{c}\text { MeBo Niskin } \\
\text { bottle } 1 \\
\text { (free) }\end{array}$ & $\begin{array}{l}\text { MeBo Niskin } \\
\text { bottle } 2 \\
\text { (pumped) }\end{array}$ & $\begin{array}{c}\text { MeBo Niskin } \\
\text { bottle } 3 \\
\text { (pumped) }\end{array}$ \\
\hline $\mathrm{CH}_{4} / \mathrm{H}_{2}$ concentrations & $\mathrm{x}$ & & & & $\mathrm{x}$ & $\mathrm{x}$ & $\mathrm{x}$ & $\mathrm{x}$ & $\mathrm{x}$ & $\mathrm{x}$ \\
\hline Helium isotopes & $\mathrm{x}$ & & & & & $\mathrm{x}$ & & & $\mathrm{x}$ & \\
\hline Dissolved inorganic carbon & $\mathrm{x}$ & & & & & $\mathrm{x}$ & & & $\mathrm{x}$ & \\
\hline Interstitial water reference & $\mathrm{x}$ & & & & & $\mathrm{x}$ & & & $\mathrm{x}$ & \\
\hline Particulate organic carbon & $\mathrm{x}$ & & & & & $\mathrm{x}$ & & & $\mathrm{x}$ & \\
\hline Organics, unfiltered & $\mathrm{x}$ & & & & & $\mathrm{x}$ & & & $\mathrm{x}$ & \\
\hline Organics, filtered & $\mathrm{x}$ & & & & & $\mathrm{x}$ & & & $\mathrm{x}$ & \\
\hline Water isotopes $\left({ }^{18} \mathrm{O},{ }^{2} \mathrm{H}\right)$ & $\mathrm{x}$ & & & & & $\mathrm{x}$ & & & $\mathrm{x}$ & \\
\hline Sulfate isotopes & $\mathrm{x}$ & & & & & $\mathrm{x}$ & & & $\mathrm{x}$ & \\
\hline Cell counts & $\mathrm{x}$ & $\mathrm{x}$ & $\mathrm{x}$ & $\mathrm{x}$ & $\mathrm{x}$ & $\mathrm{x}$ & $\mathrm{x}$ & $\mathrm{x}$ & $\mathrm{x}$ & $\mathrm{x}$ \\
\hline DNA & $\mathrm{x}$ & $\mathrm{x}$ & $\mathrm{x}$ & $\mathrm{x}$ & $\mathrm{x}$ & $\mathrm{x}$ & $\mathrm{x}$ & $\mathrm{x}$ & $\mathrm{x}$ & $\mathrm{x}$ \\
\hline
\end{tabular}

Table T8. Water sample split plan and fixation procedures in order of collection priority, Expedition 357 . Niskin bottle sample frequency $=2 \times 20 \mathrm{~mL}$ syringes from each bottle. Sediment core Rhizon sample frequency $=1 \times 20 \mathrm{~mL}$ per interval, $2 \times$ intervals per section. $\mathrm{LDPE}=$ low-density polyethylene, $\mathrm{PE}=$ polyethylene. Download table in .csv format.

\begin{tabular}{|c|c|c|c|c|}
\hline Analysis & Preparation & Measurement & $\begin{array}{l}\text { Niskin } \\
\text { bottles }\end{array}$ & $\begin{array}{c}\text { Sediment } \\
\text { core Rhizons }\end{array}$ \\
\hline Salinity & $1.5 \mathrm{~mL}$ reaction vial & Digital refractometer & 0.5 & 0.5 \\
\hline pH/alkalinity & $1.5 \mathrm{~mL}$ reaction vial & Autotitrator & 0.5 & 0.5 \\
\hline Ammonium & $1.5 \mathrm{~mL}$ reaction vial & Ammonium conductivity detector & 0.5 & 0.5 \\
\hline Cations & For every $\mathrm{mL}$ sample, add $10 \mu \mathrm{L}$ concentration $\mathrm{HNO}_{3}$ in $8 \mathrm{~mL}$ LDPE vial $\left(4^{\circ} \mathrm{C}\right)$ & OSP (ICP-OES) & 5 & 3 \\
\hline Anions & $8 \mathrm{~mL}$ LDPE vial $\left(4^{\circ} \mathrm{C}\right)$ & OSP (ion chromatography) & 5 & 3 \\
\hline Sulfide & For every $\mathrm{mL}$ sample, add $0.4 \mathrm{~mL} 5 \% \mathrm{ZnAc}$ in $2 \mathrm{~mL}$ glass vial $\left(4^{\circ} \mathrm{C}\right)$ & OSP & 3 & 1 \\
\hline Dissolved inorganic carbon & $0.2 \mu \mathrm{m}$ filtered into $12 \mathrm{~mL}$ Vacutainer containing $100 \mu \mathrm{L} 85 \%$ phosphoric acid & Postexpedition & 0.5 & 0.5 \\
\hline Dissolved organic carbon & For every $\mathrm{mL}$ sample, add $10 \mu \mathrm{L} 30 \% \mathrm{HCl}$ in $2 \mathrm{~mL}$ glass vial $\left(4^{\circ} \mathrm{C}\right)$ & Postexpedition & - & 1.5 \\
\hline Organic acids & $4 \mathrm{~mL}$ glass vial $\left(-20^{\circ} \mathrm{C}\right)$ & Postexpedition & - & 2 \\
\hline${ }^{18} \mathrm{O} / \mathrm{D}$ & $1.8 \mathrm{~mL}$ crimp vial $\left(4^{\circ} \mathrm{C}\right)$ & Postexpedition & - & 1.5 \\
\hline${ }^{34} \mathrm{~S}$ & For every $\mathrm{mL}$ sample, add $0.4 \mathrm{~mL} 5 \% \mathrm{ZnAc}$ in $2 \mathrm{~mL}$ glass vial $\left(4^{\circ} \mathrm{C}\right)$ & Postexpedition & - & 1 \\
\hline Trace metals & For every $\mathrm{mL}$ sample, add $5 \mu \mathrm{L}$ concentrated $\mathrm{HNO}_{3}$ in $8 \mathrm{~mL} \mathrm{LDPE}$ vial $\left(4^{\circ} \mathrm{C}\right)$ & OSP & 5 & 2 \\
\hline Phosphate & For every $\mathrm{mL}$ sample, add $10 \mu \mathrm{L}$ concentrated $\mathrm{HCl}$ in $6 \mathrm{~mL} \mathrm{PE}$ vial $\left(4^{\circ} \mathrm{C}\right)$ & OSP & 3 & 1 \\
\hline Residue & $20 \mathrm{~mL}$ PE vial $\left(4^{\circ} \mathrm{C}\right)$ & Postexpedition & Varies & Varies \\
\hline
\end{tabular}

\section{Sediment Rhizon sampling, split plan, and fixation}

Where feasible in sediment layers overlying hard rocks, pore water was sampled immediately after minimal curation and fasttrack MSCL analysis. Pore water was collected through $0.15 \mu \mathrm{m}$ mesh $5 \mathrm{~cm}$ long CSS-F Rhizon samplers (Rhizosphere Research Products, Netherlands) into precleaned $20 \mathrm{~mL}$ plastic syringes following established protocols (Dickens et al., 2007; Seeberg-Elverfeldt et al., 2005). Table T9 summarizes the samples collected for pore water analysis. A $3.8 \mathrm{~mm}$ hole was drilled through the plastic core liner using a spacer on the drill bit to prevent penetrating the core. A Rhizon sampler with the same diameter was then inserted into the core, and negative pressure was applied to pull pore water into the syringe. Rhizon samplers remained in the cores for 30-45 min. Usually, one to two Rhizon samples were collected per core section; more were collected depending on microbiology sampling. Rhizons were spaced 5-10 cm apart from the window cut for microbiology syringe sampling or the endcap to obtain sufficient pore water from a single interval. After collection, the filtered fluid samplers were distributed according to the split plan (Table T8). Details on the analysis of pore water chemistry are described in Fluid inorganic chemistry analyses.
Table T9. Pore fluids collected for interstitial water chemistry, Expedition 357. Download table in .csv format.

\begin{tabular}{lcc}
\hline \multicolumn{1}{c}{ Core } & Section & Interval $(\mathrm{cm})$ \\
\hline $357-M 0069 A-$ & & \\
IR & 1 & 5 \\
IR & 1 & 114 \\
$1 R$ & 2 & 47 \\
$4 R$ & 1 & 20 \\
$4 R$ & 1 & 70 \\
$4 R$ & 1 & 110 \\
$357-M 0074 A-$ & & \\
TR & 1 & 6 \\
1R & 1 & 35 \\
R & 1 & 65 \\
\hline
\end{tabular}

\section{Borehole plugs}

Expedition 357 required the ability to seal the boreholes while allowing repeated access to them in the future (for example, by remotely operated vehicle [ROV]), as outlined in the Expedition 357 Scientific Prospectus (Früh-Green et al., 2015). In addition, the sys- 
tem was required to be as unreactive as possible to ensure collection of pristine fluid samples. A downhole plug was developed (Figure F20) to be deployed by either the MeBo or RD2 system on completion of coring operations. Owing to the different drive mechanisms of the two drills, different adaptations of the plug were required.

The primary sealing component of the downhole plug is based on a water-expandable material that swells in the hole over a period of time, with the rate of swelling such that drilling can take place prior to installation. The extent of swelling must ensure a good sidewall seal is achieved when the plug is set at a depth below seafloor interpreted from survey data to be competent rock. The downhole plugs were stored in the tool rack of the drills until completion of coring. For this expedition, the swellable packer material was Elastomer 1000/60 from Reactive Downhole Tools, which was bound onto a modified drill rod.

The secondary sealing component consisted of a ball valve insert at the top of the plug system, with multiple systems of O-rings to prevent bottom seawater intrusion into the borehole. During deployment, the ball valve was set in the closed position to leave the boreholes sealed under possible future sampling efforts.

To minimize reactivity of the borehole plug, all metal components in contact with the potentially corrosive borehole environment (i.e., elevated temperatures $\left[40^{\circ} \mathrm{C}\right]$ and high $\mathrm{pH}$ ) were constructed of either titanium or coated steel (BodyCote Tech 12 Thin Coat Ceramic). In addition, the lower end of the system was constructed of polyetheretherketone (PEEK) and nylon plastic.

The downhole plug configuration contains (1) the lower expandable packer and (2) an upper tube with a top cap. It has a central inner tube that acts as the conduit to the surface. A stop ring, designed to prevent the downhole plug from falling down the hole while the packer section expands in the hole, is placed at a defined distance in the upper section. The stop ring position is set to ensure the packer seals against competent rock while the cap sits above the seafloor. At the top of the plug, the cap can be removed to allow full access to the borehole, or a valve can be opened to allow limited but controlled access to the borehole. Both can be operated through the use of an ROV. The top cap system was designed by Develogic GmBH, Hamburg, Germany.

Figure F20. Component parts of the downhole plug system used by the RD2 and MeBo drills, Expedition 357. A. Downhole plug caps can be removed to allow full access to the borehole or enable borehole fluid sampling by an ROV through a valve in the cap. B. Two additional units of the borehole plug consisting of a modified drill rod with a ball valve (leftmost end of image); another section with the swellable packer material (rightmost end of image) to achieve a sidewall seal, closing the borehole to allow fluid equilibration following coring operations; and a nylon shoe.

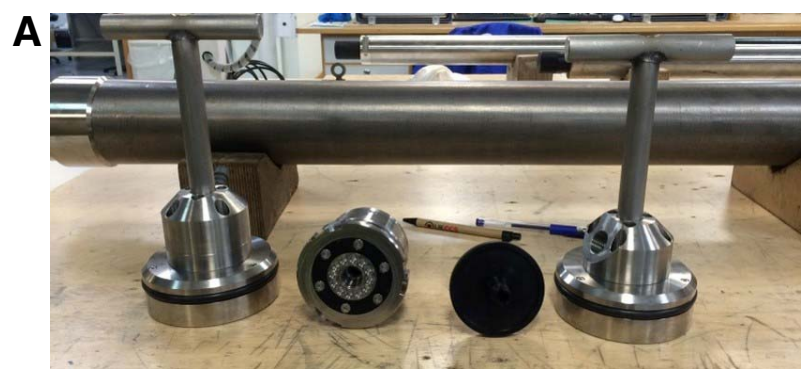

B

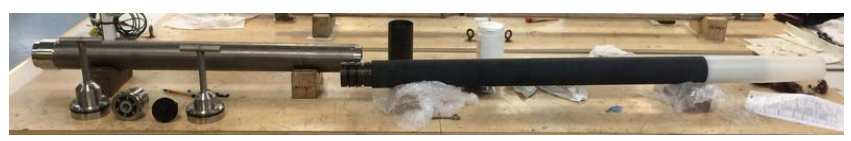

\section{Physical properties}

The physical properties measurement program for Expedition 357 included acquisition of data on whole-round sections, split cores, and samples. These measurements are valuable in characterizing lithologic units and formation properties and, in the case of nondestructive whole-core measurements, can provide useful insight into the recovered materials ahead of splitting and sampling.

Offshore, two Geotek MSCLs were used to acquire whole-core rapid magnetic susceptibility (MSCL-fast) measurements as well as slower high-resolution measurements of gamma density, noncontact resistivity, and magnetic susceptibility (a small amount of $P$ wave velocity data are available). Onshore, whole-core measurements continued with NGR and through-liner core scans undertaken ahead of the OSP in Bremen. During the OSP, digital line-scan images and color reflectance spectrophotometry measurements on split cores were acquired. In addition, samples from split cores were measured for MAD and discrete $P$-wave velocity. Measurements are presented here in the order in which they were taken.

\section{Offshore physical properties}

Shipboard measurements of physical properties were acquired to characterize lithostratigraphic units and formation properties of the recovered rocks. The data provide fast, nondestructive insight into the nature of the sampled rocks and aid the interpretation of larger scale geophysical and geological data.

To accommodate the need for quick microbiological sampling while still ensuring a continuous and consistent data set for all the recovered material, initial magnetic susceptibility measurements were undertaken using a fast-track MSCL-152 without allowing the cores to equilibrate to room temperature. With the exception of the bottommost intervals of certain holes that were sampled and immediately frozen for microbiology (see Microbiology; Table T10), every core section was measured on the fast-track MCSL. In order to minimize the time prior to microbiology sampling and maximize the efficiency of core flow, cores were logged out of order. Typically, cores sampled for microbiology were prioritized with the deepest core first, followed by the next deepest, and then every other core moving uphole. Cores not sampled for microbiology were usually measured last.

After microbiology sampling and initial core description in the deck laboratory, cores were moved to the petrophysics containerized laboratory and allowed to equilibrate to laboratory temperature $\left(\approx 19^{\circ}-21^{\circ} \mathrm{C}\right)$. Ensuring a stable laboratory temperature for these measurements was important because the majority are affected by temperature variations. Data were corrected for deviations from the optimal operating temperature for the sensors $\left(20^{\circ} \mathrm{C}\right)$. Gamma ray attenuation bulk density, $P$-wave velocity, non-

Table T10. Microbiology sampling intervals not measured on the multisensor core systems, Expedition 357. Download table in .csv format.

\begin{tabular}{cll}
\hline Hole & $\begin{array}{c}\text { Core, } \\
\text { section }\end{array}$ & $\begin{array}{c}\text { Interval } \\
(\mathrm{cm})\end{array}$ \\
\hline $357-$ & & \\
M0069A & $10 R-1$ & $106-122$ \\
M0070B & $1 R-1$ & $25-38$ \\
M0071A & $2 R-1$ & $67-86$ \\
M0076A & $10 R-1$ & $91-111$ \\
M0070C & $3 R-1$ & $71-91$ \\
M0068B & $8 R-1$ & $26-34$ \\
\hline
\end{tabular}


Table T11. Measurement time and resolution of units for parameters measured offshore on the standard multisensor core logger system, Expedition 357. NA = not applicable. Download table in .csv format.

\begin{tabular}{lcccc}
\hline \multicolumn{1}{c}{ Sensor } & Zeroing & $\begin{array}{c}\text { Measurement } \\
\text { time }(\mathrm{s})\end{array}$ & Unit & $\begin{array}{c}\text { Resolution } \\
(\mathrm{cm})\end{array}$ \\
\hline Gamma density & NA & 10 & $\mathrm{~g} / \mathrm{cm}^{3}$ & 0.5 \\
Noncontact resistivity & Yes & 5 & $\Omega \mathrm{m}$ & 2 \\
Magnetic susceptibility & Yes & 5 & $10^{-5} \mathrm{SI}$ & 2 \\
\hline
\end{tabular}

contact electrical resistivity, and magnetic susceptibility were sequentially measured using the standard MSCL-99 on whole cores (Table T11). Supplementary measurements of core diameter and temperature were used in processing data for the principal measurements. For all sensors, the sampling interval was set to $2 \mathrm{~cm}$, providing a high-resolution data set based on the amount of core and the time available. Core sections shorter than $15 \mathrm{~cm}$ were not logged, and core catcher pieces were only measured if they were 15 $\mathrm{cm}$ or longer.

\section{Fast-track magnetic susceptibility}

The fast-track MSCL consists of two Bartington MS3 meters, each coupled to a MS2C sensor coil. Both loop sensors have an internal diameter of $90 \mathrm{~mm}$. The nonstandard loops have offset frequencies of 513 and $621 \mathrm{~Hz}$ (serial numbers 467 and 466, respectively), which, on processing, require rescaling the data by the correction factors of 0.908 and 1.099 , respectively. Measurements were taken at an offset of $4 \mathrm{~cm}$ sampling interval at each sensor, giving an overall sampling rate of $2 \mathrm{~cm}$ along the length of the cores. The sampling integration period for the MS3 meters was set to $1 \mathrm{~s}$. Before logging each core, the sensor was set to zero itself. Magnetic susceptibility data are recorded as corrected volume-specific units: $K \times 10^{-5} \mathrm{SI}$. This calculation takes into account the relative effect of the diameter of the core and the diameter of the sensor coil and is performed automatically in the processing of the data:

$$
K=K_{\text {uncor }} / K_{\text {rel }}
$$

where $K_{\text {uncor }}$ is the uncorrected volume-specific magnetic susceptibility provided by the magnetic susceptibility system. $K_{\text {rel }}$ defines the relationship between the coil and core diameters as follows (Geotek MSCL Manual; http://www.geotek.co.uk/downloads):

$$
K_{\text {rel }}=4.8566\left(d / D_{1}\right)^{2}-3.0163\left(d / D_{1}\right)-0.6448
$$

A calibration check was carried out using loop-specific calibration pieces provided by the manufacturer $\left(767 \times 10^{-5} \mathrm{SI}\right.$ and $185 \times$ $10^{-5} \mathrm{SI}$ ) prior to starting fast-track measurements for each hole and every $6 \mathrm{~h}$.

\section{Gamma ray attenuation bulk density}

Gamma ray attenuation was measured by emitting a narrow beam of collimated gamma rays from a cesium-137 $\left({ }^{137} \mathrm{Cs}\right.$; half-life $=$ $30.2 \mathrm{y})$ source at one side of the core and detecting the photons passing through the core. The input gamma ray peak has a principal energy level of $0.662 \mathrm{MeV}$ that is primarily attenuated by Compton scattering. The attenuation is directly related to the number of electrons in the gamma ray beam and is a function of the core thickness and the electron density. The density of the core material is determined by measuring the number of transmitted photons that pass through the core unattenuated. Used as a proxy for bulk density, the degree of gamma ray attenuation is inversely proportional to the density of the core material, with high counts acquired from lowdensity core and low counts from high-density core. The equation used for determining bulk density from gamma ray attenuation is as follows (Geotek MSCL Manual, http://www.geotek.co.uk/downloads):

$$
\rho=1 /(\mu d) \times \ln \left(l_{0} / l\right)
$$

where

$\rho=$ sample bulk density,

$\mu=$ Compton attenuation coefficient,

$d=$ sample thickness,

$l_{0}=$ gamma source intensity, and

$l=$ measured intensity through the sample.

The $5 \mathrm{~mm}$ gamma collimator was used to maximize gamma counts performed over a count time of $10 \mathrm{~s}$. Calibration of the gamma density sensor was made using a stepped aluminum density standard placed in the same type of liner in which the cores were retrieved. Gamma counts were taken over a $60 \mathrm{~s}$ period through each of five aluminum steps of known thickness $(6,5,4,3$, and 2 $\mathrm{cm})$. Two types of calibration were performed: one with a distilled water-filled liner, simulating water-saturated material and used for sediment cores, and one in air, simulating dry material and used for hard rock cores. This calibration was checked using the water calibration piece at the start of each hole and every $6 \mathrm{~h}$ thereafter.

\section{$\boldsymbol{P}$-wave velocity}

The ultrasonic $P$-wave pulse of $230 \mathrm{kHz}$ produced by the transducer transmitter (TX) propagates through the core and is detected by the transducer receiver (RX). The received signal is amplified by automatic gain control, and the pulse timing is determined automatically by a "zero-crossing" algorithm. Negative excursions below a set threshold are detected, and the first break time is approximately one wavelength before the first zero-crossing after the first negative excursion below the threshold. The total observed time (TOT) is the sum of the pulse traveltime (TT) within the core and the $P$-wave traveltime offset (PTO). PTO includes the pulse traveltime through the liner and through the transducer faces, the delay caused by the zero-crossing algorithm picking a point on the waveform one cycle later than the onset, and electronic delays in the system circuitry. It is determined from the calibration performed with a liner filled with distilled water at a known ambient temperature. The velocity of the distilled water at the given temperature $\left(\mathrm{v}_{\mathrm{t}}\right)$ being known, PTO can be calculated from the following equations:

$$
\mathrm{PTO}=\mathrm{TOT}-X / \mathrm{v}_{\mathrm{t}}
$$

and

$$
X=D-W
$$

where $X$ is the internal diameter of the core liner and $D$ and $W$ are the distance between transducer faces and the total wall thickness, respectively. The transducers also measure displacement, monitoring small variations in the outer diameter of the core liner. These variations are used in processing not only $P$-wave velocity data but also the gamma density and magnetic susceptibility data sets. Additionally, the measured $P$-wave velocity is compensated for slight differences in temperature at the time of measurement. 
The initial calibration was checked at the start of each hole and at $6 \mathrm{~h}$ intervals thereafter using the water calibration check piece.

\section{Noncontact electrical resistivity}

Electrical resistivity was measured using a noncontact electrical resistivity sensor, which consists of two sets of transmitter-receiver coils. The transmitter generates a high-frequency magnetic field that induces electric currents in the core. The intensity of the induced currents is proportional to the conductivity of the core material and thus inversely proportional to its resistivity. The receiver coil measures the small magnetic field induced by these electric currents, which is then normalized with the measurements of the second set, operating in air. Measurements were performed with an averaging period of $5 \mathrm{~s}$. At the beginning of each core, the sensor was zeroed and a free air measurement was taken in order to account for drift.

An initial calibration was carried out with six standards of core liner filled with saline solutions with salinities of 35, 17.5, 8.75, 3.5, 1.75 , and $0.35 \mathrm{~g} / \mathrm{L}$. Calibration checks were undertaken at the beginning of each hole and every $6 \mathrm{~h}$ thereafter using the $17.5 \mathrm{~g} / \mathrm{L}$ salinity standard.

\section{Magnetic susceptibility}

Magnetic susceptibility was measured using a Bartington MS3 meter coupled to a MS2C sensor coil (serial number 725S). The standard loop sensor used during Expedition 357 has an internal diameter of $80 \mathrm{~mm}$ and a coil diameter of $88 \mathrm{~mm}$ and operates at a frequency of $565 \mathrm{~Hz}$. Similar to the loops used on the fast-track system, this loop operates at an offset frequency that requires correction on processing using a correction factor of 1.099. Magnetic susceptibility measurements on the MSCL-S were taken with a sampling integration period of $5 \mathrm{~s}$. Before logging each core, the sensor was programmed to zero itself. Magnetic susceptibility data were recorded in corrected volume-specific units $\left(\times 10^{-5} \mathrm{SI}\right)$. A calibration check was performed using the sensor-specific calibration check piece at the beginning of each hole and then every $6 \mathrm{~h}$, as with the other sensors.

\section{Data quality}

Core quality influences physical properties data quality. Optimum data quality is achieved when the core liners are completely filled. If they are not, volume-dependent gamma density, $P$-wave velocity, and magnetic susceptibility measurements may give values that are too low because the correction for volume is based on variations in the core liner diameter rather than the diameter of the core itself. $P$-wave velocity measurements require effective acoustic coupling across the core, which normally requires a combination of good core quality and fluid saturation. Cores acquired during Expedition 357 were commonly slightly undersized relative to the liner, and fluid saturation is rare, so transmission of an acoustic pulse across the core for $P$-wave velocity measurements was generally not possible. The $P$-wave velocity data set is therefore largely absent.

A full calibration of all MSCL sensors was performed at the beginning of the expedition and repeated each time the core liner type was changed (the RD2 and MeBo drills use slightly different core liners), if significant departures from the active calibration were observed, or if the system was powered down. Full calibrations were checked every $6 \mathrm{~h}$ by logging three calibration standards: distilled water, $17.5 \mathrm{~g} / \mathrm{L}$ saline water, and the magnetic susceptibility check piece.

The magnetic susceptibility loop used for measuring cores on the MSCL-S was selected to minimize the distance between the coil and the core. One oversized core section (357-M0069A-5R-1) could not pass through the $80 \mathrm{~mm}$ loop, so a $90 \mathrm{~mm}$ loop (borrowed from the fast-track system) was used instead.

\section{Natural gamma radiation \\ Onshore physical properties}

The NGR of a material is a function of the proportion of natural unstable or radioactive isotopes the material contains. In ultramafic igneous rocks, these emitters are predominantly the three major naturally occurring radioactive nuclides ${ }^{238} \mathrm{U},{ }^{232} \mathrm{Th}$, and ${ }^{40} \mathrm{~K}$ and their daughter products. Despite forming the majority of the radioactive isotopes, these elements tend to occur in extremely low abundances within ultramafic rocks (averages: $\mathrm{K}=0.003 \%, \mathrm{U}=0.001$ ppm, Th = 0.004 ppm) (Van Schmus, 1995).

NGR data were collected from all Expedition 357 cores utilizing a Geotek multiple-section MSCL (MSCL-XYZ) located in the BCR. In addition to the built-in lead shielding around the detector, two 1 $\mathrm{cm}$ thick steel plates stacked on top of each other were positioned under the apparatus to shield the effects of the concrete floor of the repository.

Once the MSCL-XYZ and cores had been allowed to equilibrate to the temperature of the core repository $\left(4^{\circ} \mathrm{C}\right)$, three standard reference materials (IAEA RGTh-1, RGK-1, and RGU-1) were utilized to calibrate the spectrum, assigning detectable energy ranges to the 1024 channels. This calibration was checked on a weekly basis. Additionally, a long background measurement was recorded over a period of $\approx 16 \mathrm{~h}$ and used to correct core data for the ambient levels of gamma radiation in the repository.

The measurement window is dictated by the detector size (7.62 $\mathrm{cm}$ ), and a $4 \mathrm{~cm}$ sampling interval was consequently employed for the majority of the cores to ensure detector overlap between adjacent measurement intervals. Exceptions to this sampling interval were made for core material recovered from priority NGR holes (M0068A, M0071C, and M0076B) where corresponding in situ measurements were acquired (see Downhole logging). These cores were measured with a $2 \mathrm{~cm}$ sampling interval. A measurement time of 3 min per sample point was used to ensure optimal data quality given the anticipated low NGR values.

Data were recorded as total counts per second (cps) using a Brightspec detector/bMCA sodium iodide scintillator (a 3 inch diameter, 2 inch thick $\mathrm{NaI}(\mathrm{Tl})$ crystal, and integral photomultiplier tube) detecting energies between 0 and $3 \mathrm{MeV}$. All data recorded were background-normalized.

\section{Through-liner digital imaging}

Through-liner digital line scan images of whole cores were obtained ahead of the OSP using the Avaatech Superslit X-ray fluorescence (XRF) core scanner at MARUM (supported by the DFGLeibniz Center for Surface Process and Climate Studies at the University of Potsdam, Germany). The scanner has an option for mounting a line-scan camera and linear light source on the system to facilitate acquisition of high-resolution color images. In addition to these images, the system outputs accurate color data in redgreen-blue (RGB) and Commission Internationale d'Eclairage $(\mathrm{CIELab})$ units $\left(\mathrm{L}^{*}=\right.$ lightness, $\mathrm{a}^{*}=$ green to red chromacity, and $\mathrm{b}^{*}$ = blue to yellow chromacity) by way of individual charge-coupled device $(C C D)$ pixel calibration. The Line Scan program uses the Stemmer Common Vision Blox platform to acquire and process color images.

The camera system contains a 3-CCD camera with beam-splitter and manually controlled Pentax $50 \mathrm{~mm}$ lens. The resulting image resolution is approximately 150 pixels $/ \mathrm{cm}$ in the cross-core and 
downcore directions. With an exposure time of $5 \mathrm{~ms}$, a scan speed of $125 \mathrm{~mm} / \mathrm{s}$ was achieved. Image coverage is approximately 13.5 $\mathrm{cm}$ in the cross-core direction and a maximum of $154 \mathrm{~cm}$ in the downcore direction.

After powering up, the line scan system was allowed to stabilize for $1 \mathrm{~h}$ before calibration was undertaken. Calibration of the equipment was done once every $24 \mathrm{~h}$ using white and black calibration pieces:

- White calibration: lens open at $\mathrm{f} / 11+$ (a fixed value between 11 and 16), scanning a white surface present within the scanner.

- Black calibration: lens closed with the lens cap and white surface covered up.

- After calibration: lens open at f/9.5.

All cores were measured using an aperture setting of f/9.5 (a fixed value between 8 and 11). This fixed setting was selected over custom settings per hole or core in order to ensure a consistent data set. Each whole-core section was scanned four times, rotating $90^{\circ}$ clockwise (looking uphole) after each scan. The initial scan was always acquired with the division between the working and archive halves up (archive half to the right). Note that this division was based on the provisional scribe marked during curation offshore and that the division of halves for splitting, defined following through-liner description, may differ.

Wherever a WRC sample was taken, a foam spacer of the same length was inserted in its place and labeled "MBIO." Four output files were generated for each core section: a high-resolution bitmap file (BMP), a compressed image file (JPEG), a tagged image file (TIF), and a numeric text file (TXT). Numeric data are presented in RGB units.

\section{Split-core digital imaging}

Similar to the process for whole cores, digital line-scan images of split cores were obtained using the line-scan camera and linear light source on the XRF core scanner. For Expedition 357, both the working and archive halves were imaged wet and dry. The wet archive image was used as the primary core image for the VCD sheets.

Every split core was imaged with a color/gray chart beside it, and this scan is available as the original file. Similar to the throughliner images, four output files were generated for each core section, with numeric data presented in RGB units. The line-scan system was calibrated every $24 \mathrm{~h}$ with black and white calibration. Unless otherwise stated on the output files, wet split cores were measured using an aperture setting of $\mathrm{f} / 9.5$ and dry split cores were measured using aperture setting $f / 11+$. Because of the variability in color of the samples from this expedition, the aperture was varied when appropriate to ensure optimal image quality. Wherever a WRC sample was removed from the core, a foam spacer was inserted in its place and marked as "MBIO" (for microbiology samples) or "TSB" (for thin section billet samples). The numeric data files were corrected to the same length as the modified BMP picture files. Both original and corrected files were made available to the science party. Composite images of the wet archive-half split cores are available in MBIOWRC in Supplementary material.

\section{Color reflectance spectrophotometry}

The color reflectance spectrophotometer measures the reflection or transmission properties of a material as a function of wavelength. During the OSP in Bremen, color reflectance was measured on the archive halves of dry rock cores. The archive halves of the few sediment cores that were recovered were measured as soon af- ter splitting as reasonably possible to ensure the highest quality data were acquired from the split surface. Sediment cores are more susceptible to change (through oxidation and fluid loss), and the original color of the sediment is therefore more ephemeral than that of rock cores.

Measurements were undertaken using a handheld Minolta spectrophotometer CM-2600d with an $8 \mathrm{~mm}$ aperture. To make the measurements more sensitive to surface conditions (notably the roughness of the surface), they were performed in the instrument's specular component excluded (SCE) mode. In this mode, the specular reflection (the light reflecting with the same angle as the incident angle but in the opposite direction) is omitted, and only the diffuse reflection that scatters in various directions is measured.

Where possible, measurements were taken every $2 \mathrm{~cm}$ along the center line of the core sections unless the core center was disturbed by a discontinuity such as a fracture or a vein. To avoid these discontinuities, measurements were shifted left or right of the centerline of the core. This information was noted in the log sheet that accompanies the data. Because of the heterogeneity of cores from this expedition and the fact that high color contrast often occurs across boundaries, it was also necessary to select measurement points that would provide the most representative data. Measurements were not performed on rubbly core intervals unless individual pieces of rubble were large enough and had been split. A detailed examination of core images, disturbance descriptions, and log sheets is recommended during analysis of spectrophotometric data.

To keep the spectrophotometer window clean, core surfaces were covered with clear plastic film (Hostaphan) before acquiring measurements.

To compensate for the effects of stray light inside the instrument (due to dust or dirt), a zero calibration was carried out every $24 \mathrm{~h}$ or whenever the system was rebooted, using the Zero Calibration Box and a white calibration piece (100\% reflection). Three measurements were taken each time for both calibration pieces. Additionally, a control measurement of the white calibration piece was carried out at the beginning and end of each core section to monitor data quality and ensure the sensor was working properly.

The spectrophotometry measurements produced three types of data:

- $\mathrm{L}^{*}, \mathrm{a}^{*}$, and $\mathrm{b}^{*}$ dimensions in the CIELab color space. $\mathrm{L}^{*}$ is the total reflectance index ranging from $0 \%$ to $100 \%$ corresponding to black and white, respectively. Negative $a^{*}$ values are green colors, and positive ones are red colors. Similarly, negative $b^{*}$ values are blue colors, and positive ones are yellow colors.

- Hue angle $(\mathrm{H})$, value (or lightness, V), and chroma (or color purity, $\mathrm{C}$ ) in the Munsell color space.

- Intensity of 31 wave bands of $10 \mathrm{~nm}$ from 400 to $700 \mathrm{~nm}$ wavelengths corresponding to the range of light visible to the human eye.

\section{Discrete sample measurements}

Cylindrical samples ( $2 \mathrm{~cm}$ in diameter; $\approx 3 \mathrm{~cm}$ in length) were cut from the working halves for both discrete triaxial $P$-wave velocity and MAD measurements. The sampling interval was variable between holes and dictated by the availability of sufficiently coherent and homogeneous material appropriate for these analyses. Given the limited number of samples from each site, sampling a range of lithologies from the different sites was important to establish some sense of the range of $P$-wave velocity and MAD values across the study area. After the wet mass (as part of the MAD measurements) was determined, $P$-wave velocities were measured before the sam- 
ples were dried and prior to acquisition of the remaining MAD measurements.

\section{Moisture and density}

Moisture content; bulk, dry, and grain densities; porosity; and void ratio were calculated from the wet and dry masses and the dry volume of samples.

After sampling, discrete samples were immediately transferred into numbered $10 \mathrm{~mL}$ borosilicate glass beakers of known mass and volume. Samples were weighed in the beakers on an electrical balance with a precision of $0.001 \mathrm{~g}$. After wet mass and $P$-wave velocity measurements were completed, samples were dried in an oven at $105^{\circ} \pm 5^{\circ} \mathrm{C}$ for at least $24 \mathrm{~h}$. On removal from the oven, samples were allowed to cool to room temperature in a desiccator for at least $1 \mathrm{~h}$ before they were weighed again to acquire the dry mass.

The dry volume was measured to a precision of $0.02 \mathrm{~cm}^{3}$ with a Quantachrome pentapycnometer based on He-displacement with a purge time of $1 \mathrm{~min}$. Volumes for each sample are given as the averages of three measurements. Four samples and one standard volume were measured in each batch. Three stainless steel spheres with a total volume of $\approx 9.2149 \mathrm{~cm}^{3}$ were used as the standard and were cycled through the 5 cells as a check for equipment functionality.

The mass and volume of the beakers were subtracted from the measured total mass and volume to give the wet mass $\left(M_{\mathrm{w}}\right)$, dry mass $\left(M_{\mathrm{d}}\right)$, and dry volume $\left(V_{\mathrm{d}}\right)$ of the sample. To account for salt precipitation from evaporating pore fluid during drying of the sample, a salt-corrected pore water mass $\left(M_{\mathrm{pw}}\right)$ was calculated:

$$
M_{\mathrm{pw}}=\left[\left(M_{\mathrm{w}}-M_{\mathrm{d}}\right) /(1-s)\right],
$$

where $s$ is the salinity of the pore fluid, which is assumed to be that of seawater (35 g/L) following Blum (1997). The salt-corrected solid mass $\left(M_{\mathrm{s}}\right)$ is then

$$
M_{\mathrm{s}}=M_{\mathrm{w}}-M_{\mathrm{pw}}
$$

The volume of the pore water $\left(V_{\mathrm{pw}}\right)$ is

$$
V_{\mathrm{pw}}=M_{\mathrm{pw}} / \rho_{\mathrm{pw}}
$$

where $\rho_{\mathrm{pw}}$ is the pore water density, assumed to be $1.024 \mathrm{~g} / \mathrm{cm}^{3}$ (Blum, 1997).

The mass of the salt itself is

$$
M_{\text {salt }}=M_{\mathrm{pw}}-\left(M_{\mathrm{w}}-M_{\mathrm{d}}\right),
$$

and its volume is

$$
V_{\text {salt }}=M_{\text {salt }} / \rho_{\text {salt }}
$$

where $\rho_{\text {salt }}$ is the density of salt $\left(2.22 \mathrm{~g} / \mathrm{cm}^{3}\right)$.

From this, the solid volume $\left(V_{\mathrm{s}}\right)$ can be calculated as

$$
V_{\mathrm{s}}=V_{\mathrm{d}}-V_{\text {salt }}
$$

and the wet volume $\left(V_{\mathrm{w}}\right)$ can be calculated as

$$
V_{\mathrm{w}}=V_{\mathrm{s}}+V_{\mathrm{pw}}
$$

Moisture content relative to the wet mass $\left(W_{\mathrm{w}}\right)$ is

$$
W_{\mathrm{w}}=M_{\mathrm{pw}} / M_{\mathrm{w}}
$$

and moisture content relative to the salt-corrected solid mass $\left(W_{\mathrm{s}}\right)$ is

$$
W_{\mathrm{s}}=M_{\mathrm{pw}} / M_{\mathrm{s}}
$$

Bulk density $\left(\rho_{b}\right)$, dry density $\left(\rho_{d}\right)$, grain density $\left(\rho_{g}\right)$, porosity $(\phi)$, and void ratio $(e)$ are defined as

$$
\begin{aligned}
& \rho_{\mathrm{b}}=M_{\mathrm{w}} / V_{\mathrm{w}}, \\
& \rho_{\mathrm{d}}=M_{\mathrm{s}} / V_{\mathrm{w}}, \\
& \rho_{\mathrm{g}}=M_{\mathrm{s}} / V_{\mathrm{s}}, \\
& \phi=V_{\mathrm{pw}} / V_{\mathrm{w}},
\end{aligned}
$$

and

$$
e=V_{\mathrm{pw}} / V_{\mathrm{s}}
$$

Because of the high heterogeneity encountered in individual cores, both the working and archive halves of all cores were digitally imaged on splitting. Each core half was imaged both wet and dry (see above), and it is therefore feasible that some pore fluid may have evaporated and some of the dissolved salt precipitated at this stage. Therefore, the solid volume of the samples may be overestimated, and the porosity and grain density may be underestimated. Salt precipitation during the $24 \mathrm{~h}$ drying between the measurement of the wet and the dry mass has been accounted for as described above, but this does not include the potential precipitation during the drying prior to the determination of the wet mass. Additionally, the correction for salt precipitation assumes seawater salinity, although the cores have been split and sampled using freshwater. These limitations should be considered when evaluating the MAD results.

\section{Discrete $P$-wave velocity}

To a large extent, this description follows that given in Expedition 325 Scientists (2011). Where the methodology used here is substantially different, mention will be made in the text.

$P$-wave velocity can be derived from the traveltime of acoustic waves passing through a sample of known thickness. $P$-wave velocity varies with lithology, porosity, saturation, and bulk density, as well as state of stress and degree of fracturing. In sediments and rocks, velocity values are also controlled by the degree of consolidation, lithification and fracturing, and the occurrence and abundance of free gas and gas hydrates.

For Expedition 357, $P$-wave velocity was measured during the OSP using a Geotek $P$-wave logger for discrete samples (MSCLDPW; http://www.geotek.co.uk/products/mscl-dpw). The equipment consists of a mechanical section containing a pair of transducers (one transmitter and one receiver), a set of electronics, and a computer. The samples were placed between the two transducers for measurement. Acoustic coupling is achieved through solid neoprene surfaces on the transducers and can be improved by applying downward pressure on the sample between transducers and/or by wetting the neoprene with distilled water. A laser distance transducer measures the thickness of the sample. Poorly consolidated samples are not suitable for measurement with the MSCL-DPW because they tend to crumble when placed between the transducers. For this reason, samples were limited to those taken from rock 
cores, with no measurements from the unconsolidated sediment core sections.

The basic velocity equation is

$$
v=d / t
$$

where

$d=$ distance traveled through the material, and

$t=$ traveltime of the $P$-wave through the material.

The MSCL-DPW was calibrated at the start and end of each set of samples. Calibration involved measurement of a Delrin sample of known length and $P$-wave velocity $(2.43 \mathrm{~km} / \mathrm{s})$, and a measurement was also taken with the transducers touching (zero distance). To monitor measurement drift, the velocity of the calibration piece was also noted at the end of each sample run.

To correct the traveltime, the delay related to the transducers and electronics and the delay related to the peak detection procedure are subtracted. These delays were determined during calibration with zero distance. For routine measurements on discrete samples with the MSCL-DPW system, the equation for velocity is

$$
v_{\text {core }}=1000 \times d_{\text {core }} /(\text { TOT }-\mathrm{PTO})
$$

where

$v_{\text {core }}=$ velocity through the sample $(\mathrm{m} / \mathrm{s})$,

$d_{\text {core }}=$ measured thickness of the sample $(\mathrm{mm})$,

TOT $=$ measured total traveltime $(\mu \mathrm{s})$, and

PTO = delay correction $(\mu s)$.

A pulse generating an ultrasonic compression wave at $\approx 230 \mathrm{kHz}$ is sent to the transmitter, propagates through the sample, and is received by the receiver. The received signal is processed through an analog-to-digital converter before being displayed. The signal is digitized at a sampling frequency of $12.5 \mathrm{MHz}$. In the software, a threshold detector determines the first positive or negative excursion on the received pulse and can be adjusted by the operator as appropriate. The pulse timing is achieved by measuring the time to the first zero crossing after the threshold has been exceeded. In this way, the traveltime measured is approximately one-half of the wavelength after the start of the pulse but is measured without any errors caused by signal amplitude. A delay, used to define the point at which the software should start its threshold detection, was set before the start of the signal.

Sample quality affects the ability to acquire $P$-wave velocity data. It was important during Expedition 357 to prepare the sample correctly in order to achieve good contact between the transducers and the samples. Preparation involved cutting cylindrical minicore samples from the working halves; trimming the ends of the cylinders to ensure there were two flat, parallel surfaces to aid good acoustics; and scribing the upcore direction on one end of the cylindrical samples.

Measurements along the minicore axis ( $x$-direction; Figure F21) provide information about the horizontal $P$-wave velocity and are given in the data files as $V_{\mathrm{Px}}$. To obtain vertical $P$-wave velocity values, samples were also mounted in the MSCL-DPW with the minicore axis horizontal ( $z$-direction) and the upcore direction vertical. These measurements are given in the data files as $V_{\mathrm{Pz}}$. A third measurement was made on the minicores mounted in the MSCL-DPW horizontally ( $y$-direction) with the upcore direction horizontal. These measurements are given in the data files as $V_{\mathrm{Py}}$. All measure- ments were performed at room temperature. Normally, the most reliable measurement would be that of the $x$-direction (horizontal), along the axis of the cylinder where two parallel surfaces should ensure good coupling with the transducer pads. The $y$ - and $z$-direction measurements are perhaps less reliable because of the curved nature of the surfaces in contact with the pads during measurement.

Data files are in tab-separated value format (TXT; http://iodp.pangaea.de) and contain a header with information about the sample followed by the measured data and calculated velocities. The waveform is recorded in two columns containing the time base and voltage changes.

\section{Downhole logging}

Downhole measurements are in situ geophysical measurements of formation physical properties. These measurements provide a continuous record and are especially important where core recovery is incomplete. The data sets complement the data acquired from the core material recovered, and common measurements can be used for core-log integration and depth matching. Such data sets include gamma radiation and magnetic susceptibility. Certain downhole measurements are unique, including borehole images. Intermediate in scale to regional geophysics and hand specimen, downhole logging data are important in linking measurements acquired preexpedition for site characterization and measurements taken on core material recovered during the expedition.

Six logging probes were taken on Expedition 357 for acquisition of in situ measurements via cableless deployment by installation through the BHAs of the seabed drills at the end of coring operations. These probes included two magnetic susceptibility sondes (MSS; both from Antares GMBH, Germany), two dual-induction logging probes (DIL; both Antares), and two gamma ray tools (one

Figure F21. Orientation of minicores taken for $P$-wave and MAD analyses, Expedition 357. $z$-direction is vertical; $x$ - and $y$-directions are horizontal. The horizontal plane is not oriented relative to a geographic reference, so $x$-and $y$-directions are referenced only to the plane between the archive and working halves.

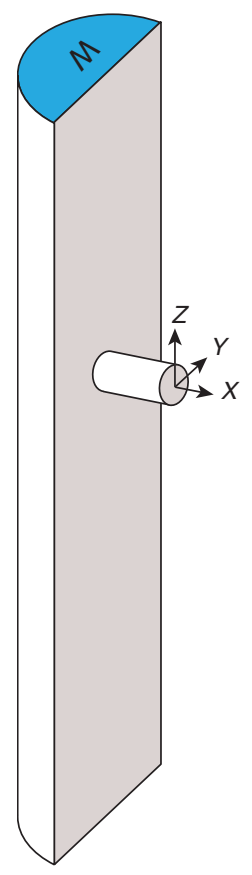


Antares spectral gamma ray [SGR] tool and one DMT opticalacoustic-gamma [OAG] hybrid tool). Unlike the conventional logging programs utilized on the other IODP platforms and previous MSP expeditions, logging from a seabed drill involves logging while tripping pipe and data acquisition to memory, rather than a realtime data feed. Data output from the tool is therefore data versus time. Integration of this data file with a depth versus time file from the seabed drills facilitates generation of a depth versus data file that can be compared effectively with the associated cores and core data sets.

Because of operational limitations encountered during drilling operations, there was unfortunately no opportunity for open-hole logging operations during Expedition 357. The operational conditions that prohibited these operations include total hole depth being called early as a consequence of stuck pipe (lost BHA means the pipe is not tripped), core barrels stuck in the BHA (preventing deployment of logging probes through the BHA), loss of operability of the winch cable (preventing logging tool deployment and/or retrieval), and insufficient hole depth to make logging probe deployment feasible. However, through-pipe gamma measurements were acquired at three sites (M0068, M0071, and M0076) during the expedition (Figure F22). These measurements are more familiar in their design, with the memory tools being deployed via cable from the seabed drills to the bottom of the BHA (or just above the stuck core barrel). Measurements were acquired as the tool was retrieved to the drill by the winch. Similar to conventional logging, depth control of cabled tools is better with the cable in tension, so the data acquired on the uplog rather than the downlog are used. Unlike wireline logging, the data were recorded to memory rather than transmitted in real time. Because these measurements were all acquired through-pipe, data output was limited to total gamma ray measurement. Attenuation of the gamma signal from the formations encountered by the drill string combined with low formation counts make it impossible to resolve the spectral make-up of the signal.

\section{Tool measurement principles}

Although the methods for the logging tools used during this expedition are different from traditional downhole logging operations, the principles of the measurements are the same. These principles are described below in combination with some details about the specific tools utilized. A summary of the main logs generated during the project are listed in Table T12. Further information regarding petrophysical measurement principles, tools, and their applications is widely available (e.g., Ellis and Singer, 2007; Goldberg, 1997; Lovell et al., 1998; Rider and Kennedy, 2011; Schlumberger, 1989; Serra, 1984, 1986, 1989).

\section{Natural gamma radiation}

NGR is a measure of the natural radioactivity of a formation. Such gamma radiation is primarily emitted from rocks as a consequence of the radioactive decay of ${ }^{40} \mathrm{~K}$ and the decay of isotopes in the ${ }^{232} \mathrm{Th}$ and ${ }^{238} \mathrm{U}$ series. During Expedition 357, total gamma ray measurements were acquired through-pipe utilizing the SGR (spectral measurements only feasible in open hole) tool for MeBo deployments and the OAG (optical and acoustic measurements are not acquired through-pipe) tool for RD2 deployments.

The OAG tool employs a $26 \mathrm{~mm} \mathrm{NaI}$ scintillation crystal, whereas the SGR uses a slightly larger $37 \mathrm{~mm}$ diameter $(250 \mathrm{~mm}$ length) CsI scintillation crystal. Both crystals are paired with a photomultiplier tube that detects pulses of light produced when gamma
Figure F22. Downhole logging tools, Expedition 357.

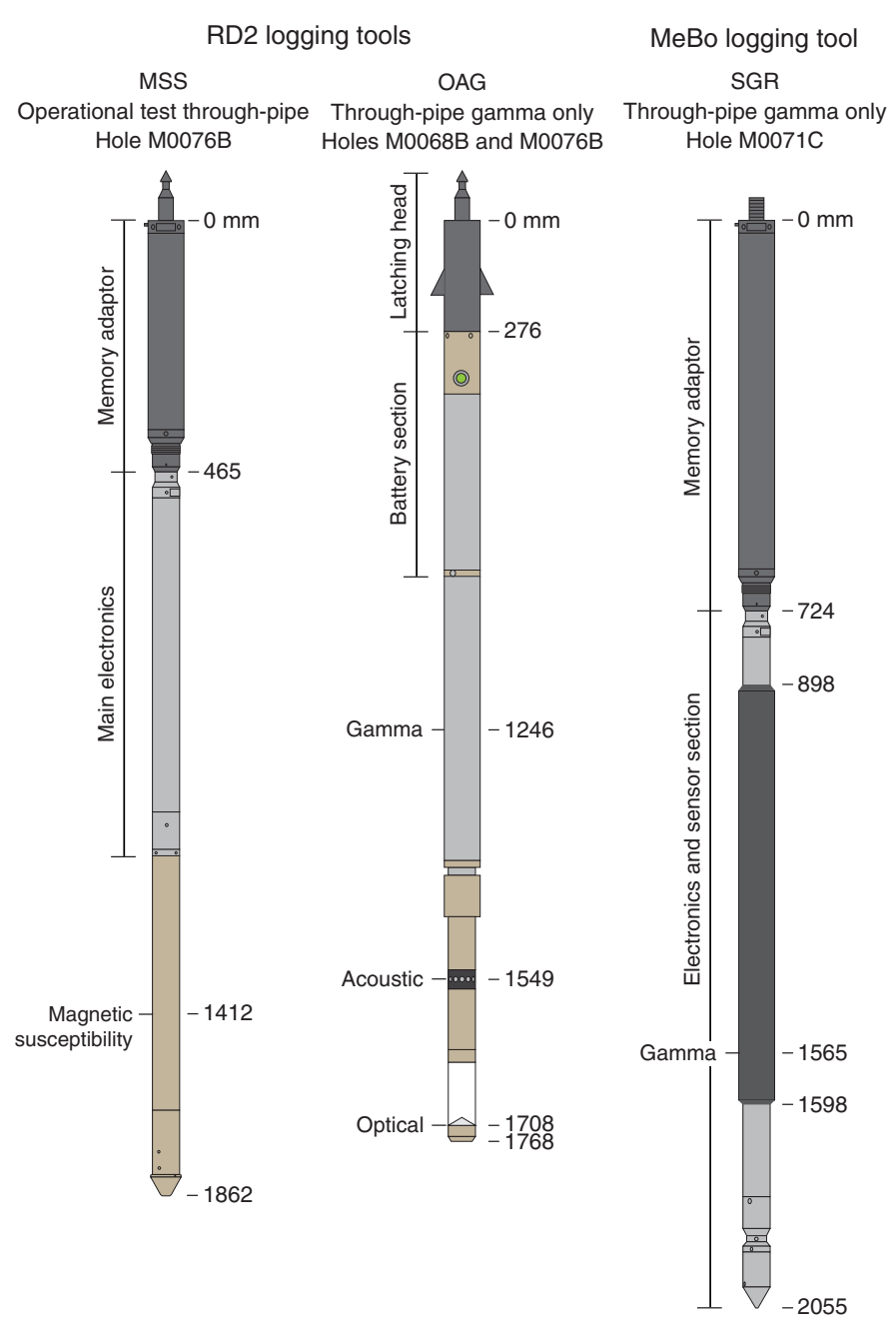

Table T12. Downhole logging tools, Expedition 357. Download table in .csv format.

\begin{tabular}{cccc}
\hline Tool & Output & Description & Unit \\
\hline OAG & Total gamma ray & DMT Optical-Acoustic-Gamma & cps \\
SGR & Total gamma ray & Antares Spectral Gamma Ray & gAPI \\
\hline
\end{tabular}

rays emitted by a formation strike the scintillation crystals. This results in small electrical currents giving a voltage pulse, the peak height of which relates to the energy of the gamma emission.

Gamma ray data are conventionally used for depth correlation between consecutive tool string runs and individual tool string passes. However, the rather unconventional nature of logging from a rock drill with individual tools deployed means that the gamma ray measurement is used purely as a measure of the natural radioactivity of the formations penetrated during the drilling process. Used in tandem with the corresponding NGR measurements taken on WRCs ahead of the OSP, these measurements may provide a means of repositioning the core material to its original depth within the borehole.

The units utilized by the gamma tools are different. OAG measurements are reported in counts per second which are uncalibrated units, and SGR measurements are reported as gamma 
Table T13. Factors affecting depth control during cabled logging operations from seabed drills, Expedition 357. Download table in .csv format.

\begin{tabular}{|c|c|c|c|}
\hline Factor & Explanation & Assumptions & Mitigation \\
\hline Time offset & $\begin{array}{l}\text { The internal clocks of the logging tools are } \\
\text { synchronized to the computer with which they are } \\
\text { programmed. Depth files are generated by the drill } \\
\text { control computers. The offset between the two } \\
\text { computers needs to be quantified before logging } \\
\text { operations as part of the tool preparation process. }\end{array}$ & $\begin{array}{l}\text { Any drift in computer time is linear } \\
\text { from the time at which the } \\
\text { computers are synchronized to } \\
\text { the time at which computer time } \\
\text { offset is noted postlogging. }\end{array}$ & $\begin{array}{l}\text { Apply a time correction as part } \\
\text { of the data processing. }\end{array}$ \\
\hline Tool time drift & $\begin{array}{l}\text { Tool time may drift from the time of programming to } \\
\text { the time at which the logging tools are returned to } \\
\text { the laboratory. The time offset between the tool and } \\
\text { the computer with which it was programmed should } \\
\text { be noted and factored in to any time-depth } \\
\text { conversions. }\end{array}$ & $\begin{array}{l}\text { Any drift in tool time is linear from } \\
\text { the time at which the tool is } \\
\text { programmed to the time at } \\
\text { which data acquisition ceases. }\end{array}$ & $\begin{array}{l}\text { Apply a time correction as part } \\
\text { of the data processing. }\end{array}$ \\
\hline
\end{tabular}

American Petroleum Institute (gAPI) units. gAPI units are industry-standard, calibrated units. Owing to the geometry of the logging during Expedition 357, with the measurements acquired throughpipe, it is advised to focus on the profile trends rather than the absolute values of these logs.

\section{Magnetic susceptibility}

As an operational test, the MSS was deployed cabled, throughpipe on one occasion during Expedition 357. Magnetic susceptibility is a measure of the extent to which a formation is magnetized in response to an applied magnetic field. The measurement is only valid when acquired in open hole with no influence from the drill string, so the data arising from this operational test are not informative for addressing the scientific questions posed by the project and the data are therefore not presented.

\section{Log data quality}

Borehole condition is the main factor affecting the quality of in situ measurements. Having an in-gauge borehole that is the diameter of the bit with no washouts or bridges is the ideal situation. Such conditions mean that tools can be effectively centralized in the borehole and that tools are measuring the formation (as opposed to the borehole fluid). In conventional downhole logging, it is commonplace to assess the borehole condition utilizing a caliper tool on the initial tool string run. This allows evaluation of the feasibility of acquiring certain measurements and provides a means by which logging data can be quality checked. However, with only single tools deployed at a time and deployment limited to through-pipe, assessment of borehole condition is reliant on information provided by the drill teams. Through-pipe deployment means that tool centralization is less of an issue when the hole is near vertical. That said, with no caliper measurement, there is no means of fully appreciating the borehole profile and its impact on the data acquired.

\section{Logging data flow and depth scales}

Depth control is a primary concern in all logging operations, regardless of the method. Appreciating the factors affecting depth and making sensible assumptions about those factors is essential to ensure that the final depth scale generated in tandem with the logging data is as good as reasonably possible. When logging from a seabed drill, depth issues are largely related to time and the accuracy with which depth is recorded rather than the ship's motion and cable stretch, which are the primary factors affecting logging from a drillship.

The factors affecting depth control in cabled logging from a seabed drill, as undertaken during Expedition 357, are as follows:
- Time drift and time offset across devices (Table T13),

- Accuracy of winch depth encoder and ability to attain constant haul rate on winch, and

- Unquantifiable cable slip.

\section{Paleomagnetism}

The key objectives of the shipboard paleomagnetic and rock magnetic work during Expedition 357 were to (1) establish a magnetic susceptibility value at each site based on 15 discrete samples of known volume and mass, (2) determine the characteristic remanence directions for future use in tectonic studies, and (3) assess whether the recovered rocks provide an appropriate source of data for investigating marine magnetic anomalies. Some background information about the parameters measured and the reason for establishing them is provided below.

\section{Fundamental magnetic properties, magnetic susceptibility, and natural remnant magnetization}

Depending on their composition, materials can display one or more of three fundamental responses to the application of an external magnetic field. The weakest response, which is inherent to all materials, is actually negative (i.e., the field induced in the sample has a polarity that opposes that of the applied field). This property is known as "diamagnetism" and is the only response exhibited, for example, by water, organic compounds, most plastics, and some minerals such as pure quartz and calcite. Collectively, these are called "diamagnets." A stronger, positive linear response ("paramagnetism") is exhibited by minerals that are "paramagnetic," and mineral examples include many members of the iron oxide phase system (e.g., lepidocrocite), the iron sulfide phase system (e.g., pyrite and marcasite), ferromagnesian minerals (e.g., biotite and pyroxene), and iron carbonates (e.g., siderite). Pure iron is "ferromagnetic," and ferromagnetism is the strongest type of positive response to an applied magnetic field. Similar ionic ordering gives rise to "ferrimagnetism" and "antiferromagnetism," which are important to paleomagnetism because of the capability of "ferromagnets" (e.g., pure iron) and "ferrimagnets" and "canted antiferromagnets" to retain a memory of a magnetic field that they were once exposed to. This memory is called "magnetic remanence." Natural minerals that behave as "ferrimagnets" at temperatures and pressures normally experienced close to the Earth's surface include magnetite, titanomagnetite, maghemite, monoclinic pyrrhotite, and greigite.

Magnetic susceptibility is a parameter that defines how easily a material can be magnetized. Geologists routinely measure this parameter at room temperature and pressure, although temperature- 
dependent measurements may detect changes in crystallographic structure, which causes magnetic transitions and can be diagnostic of specific minerals (e.g., the Verwey transition in magnetite). Magnetic susceptibility is a dimensionless ratio between the intensity of magnetization $(M)$ induced in a sample by an externally applied field $(H)$ of known intensity (i.e., $M / H)$; this ratio can span many orders of magnitude, both positive and negative. If magnetic susceptibility is expressed on a volumetric basis, volume magnetic susceptibility ( $k$ ) is obtained. Magnetic susceptibility may also be expressed per unit mass $(\mathrm{X})$, and the SI units are cubic meters per kilogram $\left(\mathrm{m}^{3} / \mathrm{kg}\right)$.

Mineral ferrimagnets have susceptibilities that are many orders of magnitude higher than paramagnets and diamagnets. Thus, even if naturally occurring ferrimagnetic minerals account for only a few parts per thousand of a sample, they dominate the magnetic susceptibility and determine its ability to acquire and carry a natural remnant magnetization (NRM). In natural sediments, NRM is commonly acquired in two fundamental ways. The first is through acquisition of a (post-)depositional remnant magnetization (pDRM). pDRMs require that when mineral grains fall out of a calm fluid suspension, the Earth's ambient magnetic field exerts a torque on them, and they align with the field. They are subsequently buried by nonmagnetic particles and are locked into position close to or just below the sediment/water interface at a depth dependent on the degree of consolidation and bioturbation. pDRMs are frequently carried by primary ferrimagnetic and antiferromagnetic iron oxides that originate from continental erosion. A second way is through precipitation of secondary authigenic and diagenetic minerals that are capable of acquiring magnetic remanence when the crystals grow and pass through the superparamagnetic to single-domain grain size threshold. This threshold is mineral specific but is often exceeded in the submicrometer grain size window.

The other mechanism of magnetization of rocks (e.g., magmas) is called thermoremnent magnetization and is defined as the magnetization an igneous rock acquires as the temperature of magma or lava from which it forms falls below the Curie point (i.e., magnetite $=580^{\circ} \mathrm{C}$, hematite $=675^{\circ} \mathrm{C}$, and ilmenite $=-233^{\circ} \mathrm{C}$ ) and during the cooling and solidification process. The thermoremnent magnetization bears the signature of the magnetic field (usually Earth's magnetic field) in which the rock is located as it forms.

The main oxide phases found in rocks acquired during Expedition 357 are magnetite and ilmenite, rutile, titanite, secondary magnetite from serpentinization of olivine in most olivine-bearing rocks, and primary and secondary sulfides.

\section{Paleomagnetic sampling and measurements}

To achieve the expedition objectives, shipboard samples for magnetic susceptibility and measurement of NRM direction and strength were obtained using discrete standard IODP paleomagnetic cylindrical cores (external dimensions of $2.54 \mathrm{~cm} \times 2.2 \mathrm{~cm}$ and a volume of $10 \mathrm{~cm}^{3}$ ) taken from the working halves of the recovered cores. Fifteen discrete samples were taken from sections that contributed to the overall magnetostratigraphy for each site with small adjustments made for voids and rock disturbances. Samples within each core section were oriented with respect to each other, and samples were marked with an arrow pointing up, indicating the direction of the top of the core. The shipboard sampling scheme was aligned with subsections of cores where the majority of shipboard and postexpedition samples were taken to better inform later research and quantify the overall lithologies recovered.

\section{Magnetic susceptibility measurements}

Magnetic susceptibility was measured using a KLY 2(AGICO) Kappabridge that operates at a frequency of $920 \mathrm{~Hz}$ and a magnetic induction of $0.4 \mathrm{mT}$ (equivalent to a field intensity of $300 \mathrm{~A} / \mathrm{m}$ ) with a noise level of $2 \times 10^{-10} \mathrm{~m}^{3} / \mathrm{kg}$. The Kappabridge was calibrated using a standard with a bulk susceptibility of $1165 \times 10^{-6} \mathrm{SI}$, and this procedure was repeated every morning before measurements began. Measurements of the 15 specimens were then corrected according to the respective averages. Volumetric samples and masses were used to make an additional estimate of bulk density that could be cross-checked with the continuous MSCL data.

\section{NRM measurements and alternating field demagnetization}

The NRM direction and intensity of the 15 discrete samples were measured using the $2 \mathrm{G}$-Enterprises horizontal pass-through superconducting rock magnetometer (SRM 755-4000) that was made available for the OSP by the University of Bremen (Germany). The standard IODP samples (i.e., cylinder cores) taken during the OSP were measured in batches of approximately eight using the pass-through conveyor sample holder belt.

A series of 15 pilot samples was selected from all sites to cover the full range of magnetic remanence. After NRM was measured, the samples were sequentially demagnetized by alternating fields at the following steps: $5,10,15,20,25,30,40,50,60,80$, and $100 \mathrm{mT}$. The magnetic remanence was measured between each step. Orthogonal plots and visualization of the demagnetization spectra were produced in Zijderveld vector diagrams, and normalized magnetic moments and directions were plotted on stereographic diagrams.

\section{References}

Arndt, N.T., and Christensen, U., 1992. The role of lithospheric mantle in continental flood volcanism: thermal and geochemical constraints. Journal of Geophysical Research: Solid Earth, 97(B7):10967-10981. http://dx.doi.org/10.1029/92JB00564

Barton, H.A., Taylor, N.M., Lubbers, B.R., and Pemberton, A.C., 2006. DNA extraction from low-biomass carbonate rock: an improved method with reduced contamination and the low-biomass contaminant database. Journal of Microbiological Methods, 66(1):21-31. http://dx.doi.org/10.1016/j.mimet.2005.10.005

Beaupré, S.R., Druffel, E.R.M., and Griffin, S., 2007. A low-blank photochemical extraction system for concentration and isotopic analysis of marine dissolved organic carbon. Limnology and Oceanography: Methods, 5(6):174-184. http://dx.doi.org/10.4319/lom.2007.5.174

Blum, P., 1997. Technical Note 26: Physical Properties Handbook-A Guide to the Shipboard Measurement of Physical Properties of Deep-Sea Cores. Ocean Drilling Program. http://dx.doi.org/10.2973/odp.tn.26.1997

Boschi, C., Früh-Green, G.L., Delacour, A., Karson, J.A., and Kelley, D.S., 2006. Mass transfer and fluid flow during detachment faulting and development of an oceanic core complex, Atlantis Massif (MAR $\left.30^{\circ} \mathrm{N}\right)$. Geochemistry, Geophysics, Geosystems, 7(1):Q01004.

http://dx.doi.org/10.1029/2005GC001074

Brazelton, W.J., Ludwig, K.A., Sogin, M.L., Andreishcheva, E.N., Kelley, D.S., Shen, C.-C., Edwards, R.L., and Baross, J.A., 2010. Archaea and bacteria with surprising microdiversity show shifts in dominance over 1,000-year time scales in hydrothermal chimneys. Proceedings of the National Academy of Sciences of the United States of America, 107(4):1612-1671. http://dx.doi.org/10.1073/pnas.0905369107

Brazelton, W.J., Morrill, P.L., Szponar, N., and Schrenk, M.O., 2013. Bacterial communities associated with subsurface geochemical processes in conti- 
nental serpentinite springs. Applied and Environmental Microbiology, 79(13):3906-3916. http://dx.doi.org/10.1128/AEM.00330-13

Carpentier, M., Weis, D., and Chauvel, C., 2013. Large U loss during weathering of upper continental crust: the sedimentary record. Chemical Geology, 340:91-104. http://dx.doi.org/10.1016/j.chemgeo.2012.12.016

Chung, F.H., 1974. Quantitative interpretation of X-ray diffraction patterns of mixtures. I. Matrix-flushing method for quantitative multicomponent analysis. Journal of Applied Crystallography, 7(6):519-525. http://dx.doi.org/10.1107/S0021889874010375

Cline, J.D., 1969. Spectrophotometric determination of hydrogen sulfide in natural waters. Limnology and Oceanography, 14(3):454-458. http://dx.doi.org/10.4319/lo.1969.14.3.0454

Collier, J., Schumacher, S., Behrens, C., Driemel, A., Diepenbroek, M., Grobe, H., Kim, T., Schindler, U., Sieger, R., and Wallrabe-Adams, H.-J., 2015. Rescued from the deep: publishing scientific ocean drilling long tail data. GeoResJ, 6:17-20. http://dx.doi.org/10.1016/j.grj.2015.01.003

Compton, R.R., 1962. Manual of Field Geology: New York (John Wiley and Sons, Inc.).

Cowie, G.L., and Hedges, J.I., 1992a. Improved amino acid quantification in environmental samples: charge-matched recovery standards and reduced analysis time. Marine Chemistry, 37(3-4):223-238.

http://dx.doi.org/10.1016/0304-4203(92)90079-P

Cowie, G.L., and Hedges, J.I., 1992b. Sources and reactivities of amino acids in a coastal marine environment. Limnology and Oceanography, 37(4):703724. http://dx.doi.org/10.4319/lo.1992.37.4.0703

Dick, H.J.B., Natland, J.H., Miller, D.J., et al., 1999. Proceedings of the Ocean Drilling Program, Initial Reports, 176: College Station, TX (Ocean Drilling Program). http://dx.doi.org/10.2973/odp.proc.ir.176.1999

Dickens, G.R., Koelling, M., Smith, D.C., Schneiders, L., and the IODP Expedition 302 Scientists, 2007. Rhizon sampling of pore waters on scientific drilling expeditions: an example from the IODP Expedition 302, Arctic Coring Expedition (ACEX). Scientific Drilling, 4:22-25. http://dx.doi.org/10.2204/iodp.sd.4.08.2007

Diepenbroek, M., Grobe, H., Reinke, M., Schindler, U., Schlitzer, R., Sieger, R., and Wefer, G., 2002. PANGAEA-an information system for environmental sciences. Computers \& Geosciences, 28(10):1201-1210. http://dx.doi.org/10.1016/S0098-3004(02)00039-0

Diepenbroek, M., Grobe, H., Reinke, M., Schlitzer, R., and Sieger, R., 1999. Data management of proxy parameters with PANGAEA. In Fischer, G., and Wefer, G. (Eds.), Use of Proxies in Paleoceanography: Examples from the South Atlantic: Heidelberg, Germany (Springer-Verlag), 715-727. http://dx.doi.org/10013/epic.11224

Ellis, D.V., and Singer, J.M., 2007. Well Logging for Earth Scientists (2nd edition): New York (Elsevier).

Expedition 304/305 Scientists, 2006. Methods. In Blackman, D.K., Ildefonse, B., John, B.E., Ohara, Y., Miller, D.J., MacLeod, C.J., and the Expedition 304/305 Scientists, Proceedings of the Integrated Ocean Drilling Program, 304/305: College Station, TX (Integrated Ocean Drilling Program Management International, Inc.). http://dx.doi.org/10.2204/iodp.proc.304305.102.2006

Expedition 325 Scientists, 2011. Methods. In Webster, J.M., Yokoyama, Y., Cotterill, C., and the Expedition 325 Scientists, Proceedings of the Integrated Ocean Drilling Program, 325: Tokyo (Integrated Ocean Drilling Program Management International, Inc.).

http://dx.doi.org/10.2204/iodp.proc.325.102.2011

Expedition 327 Scientists, 2011. Methods. In Fisher, A.T., Tsuji, T., Petronotis, K., and the Expedition 327 Scientists, Proceedings of the Integrated Ocean Drilling Program, 327: Tokyo (Integrated Ocean Drilling Program Management International, Inc.).

http://dx.doi.org/10.2204/iodp.proc.327.102.2011

Expedition 329 Scientists, 2011. Methods. In D'Hondt, S., Inagaki, F., Alvarez Zarikian, C.A., and the Expedition 329 Scientists, Proceedings of the Integrated Ocean Drilling Program, 329: Tokyo (Integrated Ocean Drilling Program Management International, Inc.). http://dx.doi.org/10.2204/iodp.proc.329.102.2011

Expedition 336 Scientists, 2012. Methods. In Edwards, K.J., Bach, W., Klaus, A., and the Expedition 336 Scientists, Proceedings of the Integrated Ocean
Drilling Program, 330: Tokyo (Integrated Ocean Drilling Program Management International, Inc.). http://dx.doi.org/10.2204/iodp.proc.336.102.2012

Flanagan, F.J., 1984. Three USGS mafic rock reference samples, W-2, DNC-1, and BIR-1. U.S. Geological Survey Bulletin, 1623. https://pubs.usgs.gov/bul/1623/report.pdf

Frey, F.A., Jones, W.B., Davies, H., and Weis, D., 1991. Geochemical and petrologic data for basalts from Sites 756, 757, and 758: implications for the origin and evolution of the Ninetyeast Ridge. In Weissel, J., Peirce, J., Taylor, E., Alt, J., et al., Proceedings of the Ocean Drilling Program, Scientific Results, 121: College Station, TX (Ocean Drilling Program), 611-659. http://dx.doi.org/10.2973/odp.proc.sr.121.163.1991

Früh-Green, G.L., Orcutt, B.N., and Green, S., 2015. Expedition 357 Scientific Prospectus: Atlantis Massif Serpentinization and Life. International Ocean Discovery Program. http://dx.doi.org/10.14379/iodp.sp.357.2015

Früh-Green, G.L., Orcutt, B.N., Green, S.L., Cotterill, C., Morgan, S., Akizawa, N., Bayrakci, G., Behrmann, J.-H., Boschi, C., Brazelton, W.J., Cannat, M., Dunkel, K.G., Escartin, J., Harris, M., Herrero-Bervera, E., Hesse, K., John, B.E., Lang, S.Q., Lilley, M.D., Liu, H.-Q., Mayhew, L.E., McCaig, A.M., Menez, B., Morono, Y., Quéméneur, M., Rouméjon, S., Sandaruwan Ratnayake, A., Schrenk, M.O., Schwarzenbach, E.M., Twing, K.I., Weis, D., Whattam, S.A., Williams, M., and Zhao, R., 2017a. Eastern sites. In Früh-Green, G.L., Orcutt, B.N., Green, S.L., Cotterill, C., and the Expedition 357 Scientists, Atlantis Massif Serpentinization and Life. Proceedings of the International Ocean Discovery Program, 357: College Station, TX (International Ocean Discovery Program). http://dx.doi.org/10.14379/iodp.proc.357.103.2017

Gieskes, J.M., Gamo, T., and Brumsack, H., 1991. Technical Note 15: Chemical Methods for Interstitial Water Analysis Aboard JOIDES Resolution. Ocean Drilling Program. http://dx.doi.org/10.2973/odp.tn.15.1991

Gillis, K.M., Snow, J.E., Klaus, A., Guerin, G., Abe, N., Akizawa, N., Ceuleneer, G., Cheadle, M.J., Adrião, Á., Faak, K., Falloon, T.J., Friedman, S.A., Godard, M.M., Harigane, Y., Horst, A.J., Hoshide, T., Ildefonse, B., Jean, M.M., John, B.E., Koepke, J.H., Machi, S., Maeda, J., Marks, N.E., McCaig, A.M., Meyer, R., Morris, A., Nozaka, T., Python, M., Saha, A., and Wintsch, R.P., 2014. Methods. In Gillis, K.M., Snow, J.E., Klaus, A., and the Expedition 345 Scientists, Proceedings of the Integrated Ocean Drilling Program, 345: College Station, TX (Integrated Ocean Drilling Program). http://dx.doi.org/10.2204/iodp.proc.345.102.2014

Goldberg, D., 1997. The role of downhole measurements in marine geology and geophysics. Reviews of Geophysics, 35(3):315-342. http://dx.doi.org/10.1029/97RG00221

Grasshoff, K., Ehrhardt, M., and Kemling, K. (Eds.), 1983. Methods of Seawater Analysis (2nd edition): Weinheim, Germany (Verlag Chemie).

Hall, P.O.J., and Aller, R.C., 1992. Rapid, small-volume, flow injection analysis for $\Sigma \mathrm{CO}_{2}$ and $\mathrm{NH}_{4}{ }^{+}$in marine and freshwaters. Limnology and Oceanography, 37(5):1113-1119. http://dx.doi.org/10.4319/lo.1992.37.5.1113

Hatzenpichler, R., and Orphan, V.J., 2015. Detection of protein-synthesizing microorganisms in the environment via bioorthogonal noncanonical amino acid tagging (BONCAT). In McGenity, T.J., Timmis, K.N., and Nogales, B. (Eds.), Hydrocarbon and Lipid Microbiology Protocols: Heidelberg, Germany (Springer-Verlag), 145-147. http://dx.doi.org/10.1007/8623_2015_61

Hickson, C.J., and Juras, S.J., 1986. Sample contamination by grinding. Canadian Mineralogist, 24:585-589.

Hofmann, A.W., 1997. Mantle geochemistry: the message from oceanic volcanism. Nature, 385(6613):219-229. http://dx.doi.org/10.1038/385219a0

Imai, N., Terashima, S., Itoh, S., and Ando, A., 1995. 1994 compilation of analytical data for minor and trace elements in seventeen GSJ geochemical reference samples, "igneous rock series." Geostandards and Geoanalytical Research, 19(2):135-213. http://dx.doi.org/10.1111/j.1751-908X.1995.tb00158.x

Inagaki, F., Hinrichs, K.-U., Kubo, Y., Bowles, M.W., Heuer, V.B., Long, W.-L., Hoshino, T., Ijiri, A., Imachi, H., Ito, M., Kaneko, M., Lever, M.A., Lin, Y.S., Methé, B.A., Morita, S., Morono, Y., Tanikawa, W., Bihan, M., Bowden, 
S.A., Elvert, M., Glombitza, C., Gross, D., Harrington, G.J., Hori, T., Li, K., Limmer, D., Liu, C.-H., Murayama, M., Ohkouchi, N., Ono, S., Park, Y.-S., Phillips, S.C., Prieto-Mollar, X., Purkey, M., Riedinger, N., Sanada, Y., Sauvage, J., Snyder, G., Susilawati, R., Takano, Y., Tasumi, E., Terada, T., Tomaru, H., Trembath-Reichert, E., Wang, D.T., and Yamada, Y., 2015. Exploring deep microbial life in coal-bearing sediment down to $\sim 2.5 \mathrm{~km}$ below the ocean floor. Science, 349(6246):420-424.

http://dx.doi.org/10.1126/science.aaa6882

Jacobson Meyers, M.E., Sylvan, J.B., and Edwards, K.J., 2014. Extracellular enzyme activity and microbial diversity measured on seafloor exposed basalts from Loihi Seamount indicate the importance of basalts to global biogeochemical cycling. Applied and Environmental Microbiology, 80(16):4854-4864. http://dx.doi.org/10.1128/AEM.01038-14

Lang, S.Q., Früh-Green, G.L., Bernasconi, S.M., and Butterfield, D.A., 2013. Source of organic nitrogen at the serpentinite-hosted Lost City hydrothermal field. Geobiology, 11(2):154-169. http://dx.doi.org/10.1111/gbi.12026

Le Bas, M.J., and Streckheisen, A.L., 1991. The IUGS systematics of igneous rocks. Journal of the Geological Society, 148(5):825-833. http://dx.doi.org/10.1144/gsjgs.148.5.0825

Le Maitre, R.W., 1989. A Classification of Igneous Rocks and Glossary of Terms: Oxford, United Kingdom (Blackwell Science Publishing).

Lever, M.A., Alperin, M., Engelen, B., Inagaki, F., Nakagawa, S., Steinsbu, B.O., Teske A., and IODP Expedition 301 Scientists, 2006. Trends in basalt and sediment core contamination during IODP Expedition 301. Geomicrobiology Journal, 23(7):517-530.

http://dx.doi.org/10.1080/01490450600897245

Lever, M.A., Rouxel, O., Alt, J.C., Shimizu, N., Ono, S., Coggon, R.M., Shanks, W.C., III, Laphan, L., Elvert, M., Prieto-Mollar, X., Hinrichs, K.-U., Inagaki, F., and Teske, A., 2013. Evidence for microbial carbon and sulfur cycling in deeply buried ridge flank basalt. Science, 339(6125):1305-1308. http://dx.doi.org/10.1126/science.1229240

Lever, M.A., Torti, A., Eickenbusch, P., Michaud, A.B., Šantl-Temkiv, T., and Jørgensen, B.B., 2015. A modular method for the extraction of DNA and RNA, and the separation of DNA pools from diverse environmental sample types. Frontiers in Microbiology, 6:1-25.

http://dx.doi.org/10.3389/fmicb.2015.00476

Lovell, M.A., Harvey, P.K., Brewer, T.S., Williams, C., Jackson, P.D., and Williamson, G., 1998. Application of FMS images in the Ocean Drilling Program: an overview. In Cramp, A., MacLeod, C.J., Lee, S.V., and Jones, E.J.W. (Eds.), Geological Evolution of Ocean Basins: Results from the Ocean Drilling Program. Geological Society Special Publication, 131(1):287-303. http://dx.doi.org/10.1144/GSL.SP.1998.131.01.18

Mei, N., Zergane, N., Postec, A., Erauso, G., Ollier, A., Payri, C., Pelletier, B., Fardeau, M.-L., Ollivier, B., and Quéméneur, M., 2014. Fermentative hydrogen production by a new alkaliphilic Clostridium sp. (strain $\mathrm{PROH} 2$ ) isolated from a shallow submarine hydrothermal chimney in Prony Bay, New Caledonia. International Journal of Hydrogen Energy, 39(34):19465-19473.

http://dx.doi.org/10.1016/j.ijhydene.2014.09.111

Moore, D.M., and Reynolds, R.C., Jr., 1989. Quantitative analysis. In Moore, D.M., and Reynolds, R.C., Jr. (Eds.), X-Ray Diffraction and the Identification and Analysis of Clay Minerals: New York (Oxford University Press USA), 272-309.

Morono, Y., Terada, T., Kallmeyer, J., and Inagaki, F., 2013. An improved cell separation technique for marine subsurface sediments: applications for high-throughput analysis using flow cytometry and cell sorting. Environmental Microbiology, 15(10):2841-2849.

http://dx.doi.org/10.1111/1462-2920.12153

Morono, Y., Terada, T., Masui, N., and Inagaki, F., 2009. Discriminative detection and enumeration of microbial life in marine subsurface sediments. The ISME Journal, 3(5):503-511. http://dx.doi.org/10.1038/ismej.2009.1

Morono, Y., Terada, T., Nishizawa, M., Ito, M., Hillion, F., Takahata, N., Sano, Y., and Inagaki, F., 2011. Carbon and nitrogen assimilation in deep subseafloor microbial cells. Proceedings of the National Academy of Sciences of the United States of America, 108(45):18295-18300.

http://dx.doi.org/10.1073/pnas.1107763108

Norman, M.D., and Garcia, M.O., 1999. Primitive magmas and source characteristics of the Hawaiian plume: petrology and geochemistry of shield picrites. Earth and Planetary Science Letters, 168(1-2):27-44. http://dx.doi.org/10.1016/S0012-821X(99)00043-6

Quéméneur, M., Bes, M., Postec, A., Mei, N., Hamelin, J., Monnin, C., Chavagnac, V., Payri, C., Pelletier, B., Guentas-Dombrowsky, L., Gérard, M., Pisapia, C., Gérard, E., Ménez, B., Ollivier, B., and Erauso, G., 2014. Spatial distribution of microbial communities in the shallow submarine alkaline hydrothermal field of the Prony Bay, New Caledonia. Environmental Microbiology Reports, 6(6):665-674. http://dx.doi.org/10.1111/1758-2229.12184

Quéméneur, M., Palvadeau, A., Postec, A., Monnin, C., Chavagnac, V., Ollivier, B., and Erauso, G., 2015. Endolithic microbial communities in carbonate precipitates from serpentinite-hosted hyperalkaline springs of the Voltri Massif (Ligurian Alps, Northern Italy). Environmental Science and Pollution Research, 22(18):13613-13624. http://dx.doi.org/10.1007/s11356-015-4113-7

Rider, M.H., and Kennedy, M., 2011. The Geological Interpretation of Well Logs (3rd edition): Sutherland, United Kingdom (Rider-French Consulting Limited).

Rounds, S.A., 2012. Chapter A6. Section 6.6. Alkalinity and acid neutralizing capacity (revised). National Field Manual for the Collection of WaterQuality Data (TWRI Book 9): Handbooks for Water-Resources Investigations. http://water.usgs.gov/owq/FieldManual/Chapter6/section6.6/

Schlumberger, 1989. Log Interpretation Principles/Applications: Houston (Schlumberger Education Services), SMP-7017.

Schrenk, M.O., Kelley, D.S., Delaney, J.R., and Baross, J.A., 2003. Incidence and diversity of microorganisms within the walls of an active deep-sea sulfide chimney. Applied and Environmental Microbiology, 69(6):35803592. http://dx.doi.org/10.1128/AEM.69.6.3580-3592.2003

Schudel, G., Lai, V., Schudel, G., Lai, V., Gordon, K., and Weis, D., 2015. Trace element characterization of USGS reference materials by HR-ICP-MS and Q-ICP-MS. Chemical Geology, 410:223-236. http://dx.doi.org/10.1016/j.chemgeo.2015.06.006

Schwarzenbach, E.M., Früh-Green, G.L., Bernasconi, S.M., Alt, J.C., and Plas, A., 2013. Serpentinization and carbon sequestration: a study of two ancient peridotite-hosted hydrothermal systems. Chemical Geology, 351:115-133. http://dx.doi.org/10.1016/j.chemgeo.2013.05.016

Seeberg-Elverfeldt, J., Schlüter, M., Feseker, T., and Kölling, M., 2005. Rhizon sampling of porewaters near the sediment-water interface of aquatic systems. Limnology and Oceanography: Methods, 3(8):361-371. http://aslo.org/lomethods/free/2005/0361.pdf

Serra, O., 1984. Fundamentals of Well-Log Interpretation (Volume 1): The Acquisition of Logging Data: Amsterdam (Elsevier).

Serra, O., 1986. Fundamentals of Well-Log Interpretation (Volume 2): The Interpretation of Logging Data: Amsterdam (Elsevier).

Serra, O., 1989. Formation MicroScanner Image Interpretation: Houston (Schlumberger Education Services), SMP-7028.

Shelley, D., 1983. Igneous and Metamorphic Rocks under the Microscope: Classification, Textures, Microstructures and Mineral Preferred Orientations: London (Chapman and Hall).

Shipboard Scientific Party, 1999. Explanatory notes. In Dick, H.J.B., Natland, J.H., Miller, D.J., et al., Proceedings of the Ocean Drilling Program, Initial Reports, 176: College Station, TX (Ocean Drilling Program), 1-42. http://dx.doi.org/10.2973/odp.proc.ir.176.102.1999

Shipboard Scientific Party, 2004. Explanatory notes. In Kelemen, P.B., Kikawa, E., Miller, D.J., et al., Proceedings of the Ocean Drilling Program, Initial Reports, 209: College Station, TX (Ocean Drilling Program), 1-75. http://dx.doi.org/10.2973/odp.proc.ir.209.102.2004

Smith, D.C., Spivack, A.J., Fisk, M.R., Haveman, S.A., Staudigel, H., and the Leg 185 Shipboard Scientific Party, 2000. Technical Note 28: Methods for Quantifying Potential Microbial Contamination during Deep Ocean Coring. Ocean Drilling Program. http://dx.doi.org/10.2973/odp.tn.28.2000 Stepanauskas, R., and Sieracki, M.E., 2007. Matching phylogeny and metabolism in the uncultured marine bacteria, one cell at a time. Proceedings of 
the National Academy of Science of the United States of America, 104(21):9052-9057. http://dx.doi.org/10.1073/pnas.0700496104

Streckeisen, A., 1974. Classification and nomenclature of plutonic rocks recommendations of the IUGS subcommission on the systematics of igneous rocks. Geologische Rundschau, 63(2):773-786.

http://dx.doi.org/10.1007/BF01820841

Suzuki, S., Kuenen, J.G., Schipper, K., van der Velde, S., Ishii, S., Wu, A., Sorokin, D.Y., Tenney, A., Meng, X.Y., Morrill, P.L., Kamagata, Y., Muyzer, G., and Nealson, K.H., 2014. Physiological and genomic features of highly alkaliphilic hydrogen-utilizing Betaproteobacteria from a continental serpentinizing site. Nature Communications, 5:3900. http://dx.doi.org/10.1038/ncomms4900

Tamburini, C., Boutrif, M., Garel, M., Colwell, R.R., and Deming, J.W., 2013. Prokaryotic responses to hydrostatic pressure in the ocean - a review.
Environmental Microbiology, 15(5):1262-1274.

http://dx.doi.org/10.1111/1462-2920.12084

Tucker, M.E., 1988. Techniques in Sedimentology: Oxford, United Kingdom (Blackwell Science Publishing).

Twing, K.I., 2015. Microbial diversity and metabolic potential of the serpentinite subsurface environment (Ph.D. dissertation). Michigan State University. http://gradworks.umi.com/37/39/3739219.html

Van Schmus, W.R., 1995. Natural radioactivity of the crust and mantle. In Ahrens, T.J. (Ed.), Global Earth Physics: Washington, DC (American Geophysical Union), 283-291. http://dx.doi.org/10.1029/RF001p0283

Wilson, S.A., 1997. Data compilation for USGS reference material BHVO-2, Hawaiian Basalt. Open-File Report - United States Geological Survey.

Young, C., and Lupton, J.E., 1983. An ultratight fluid sampling system using cold-welded copper tubing. Eos, Transactions of the American Geophysical Union, 64:735. 